\title{
King County Metro Transit Hybrid Articulated Buses: Final Evaluation Results
}

\section{Technical Report} NREL/TP-540-40585

December 2006

K. Chandler

Battelle

K. Walkowicz

National Renewable Energy Laboratory

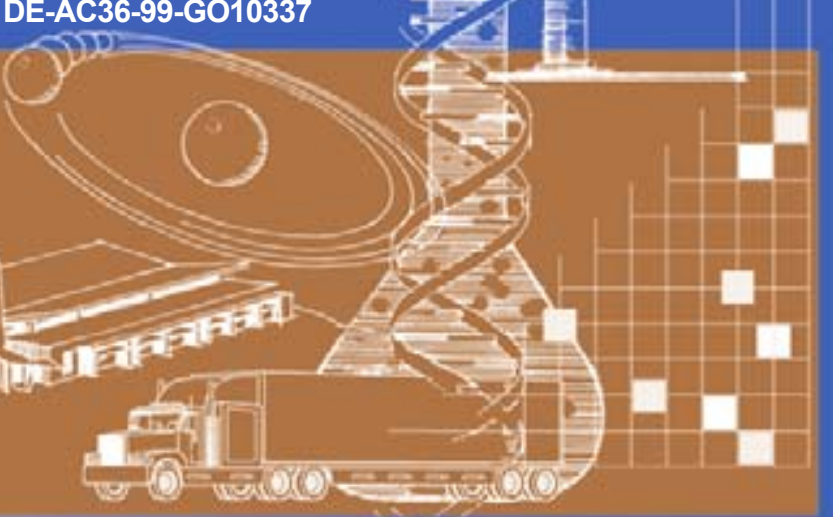




\section{King County Metro Transit Hybrid Articulated Buses: Final Evaluation Results}

\section{Technical Report}

NREL/TP-540-40585

December 2006

K. Chandler

Battelle

K. Walkowicz

National Renewable Energy Laboratory

Prepared under Task No. FC07.3000

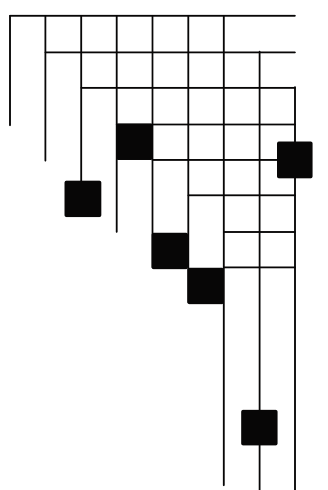




\section{NOTICE}

This report was prepared as an account of work sponsored by an agency of the United States government. Neither the United States government nor any agency thereof, nor any of their employees, makes any warranty, express or implied, or assumes any legal liability or responsibility for the accuracy, completeness, or usefulness of any information, apparatus, product, or process disclosed, or represents that its use would not infringe privately owned rights. Reference herein to any specific commercial product, process, or service by trade name, trademark, manufacturer, or otherwise does not necessarily constitute or imply its endorsement, recommendation, or favoring by the United States government or any agency thereof. The views and opinions of authors expressed herein do not necessarily state or reflect those of the United States government or any agency thereof.

Available electronically at http://www.osti.gov/bridge

Available for a processing fee to U.S. Department of Energy and its contractors, in paper, from:

U.S. Department of Energy

Office of Scientific and Technical Information

P.O. Box 62

Oak Ridge, TN 37831-0062

phone: 865.576 .8401

fax: 865.576 .5728

email: mailto:reports@adonis.osti.gov

Available for sale to the public, in paper, from:

U.S. Department of Commerce

National Technical Information Service

5285 Port Royal Road

Springfield, VA 22161

phone: 800.553.6847

fax: 703.605.6900

email: orders@ntis.fedworld.gov

online ordering: http://www.ntis.gov/ordering.htm 


\section{Acknowledgements}

This evaluation is funded through the Advanced Vehicle Testing Activity, which is managed by Lee Slezak within the FreedomCAR \& Vehicle Technologies Program in the U.S. Department of Energy (DOE). All publications on the King County Metro Transit hybrid bus evaluation will be posted on the DOE Office of Energy Efficiency and Renewable Energy Web site. Please see http://www1.eere.energy.gov/vehiclesandfuels/avta.

This evaluation conducted at King County Metro Transit (KC Metro) would not have been possible without the support and cooperation of many people. Therefore, the authors wish to thank each of the following:

\section{U.S. Department of Energy}

Lee Slezak

NREL

Leslie Eudy

KC Metro

Jim Boon

Colleen Duke

Bernie Durant

Todd Gibbs

Ann Gonzales

Wayne Hom

Lynn Matteoni

Jo Merrick

George Stites

GM Allison

Peter Chiang

Paul Nama

New Flyer Industries

Rick Brandenburg

Paul Zanetel

\section{Caterpillar}

Dave Bradshaw

NC Power

Bill Hofer

Craig Johnson 


\section{Table of Contents}

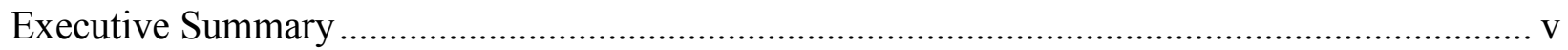

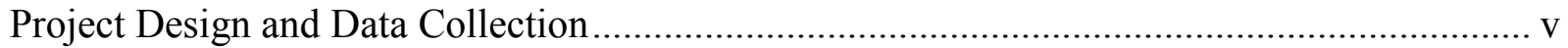

Hybrid and Diesel Buses...................................................................................................... vi

Implementation Experience ……………............................................................................. $\mathrm{vi}$

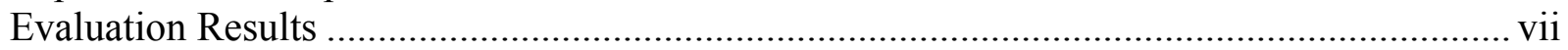

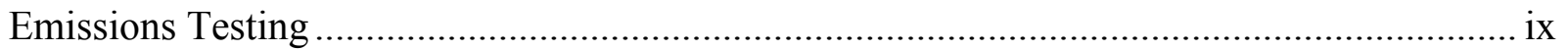

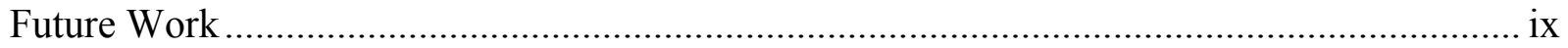

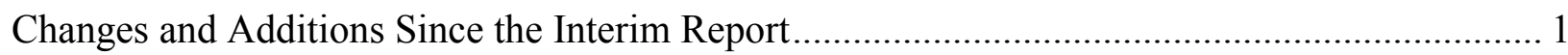

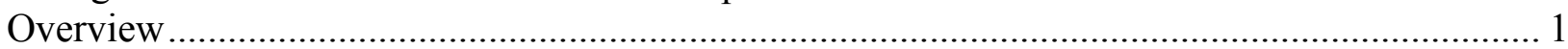

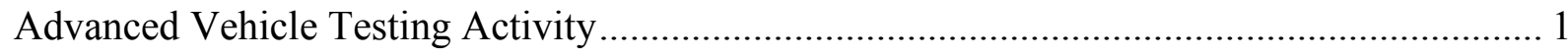

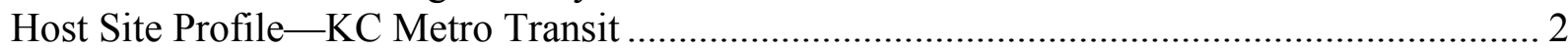

Description of the KC Metro Hybrid Transit Bus Project ........................................................ 2

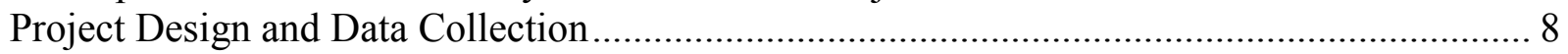

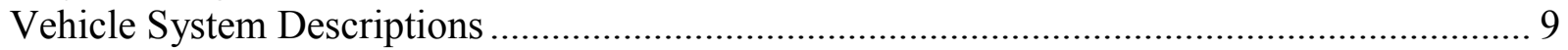

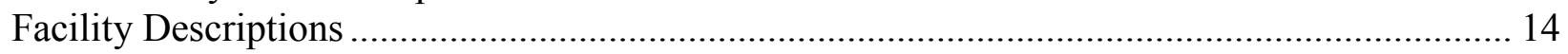

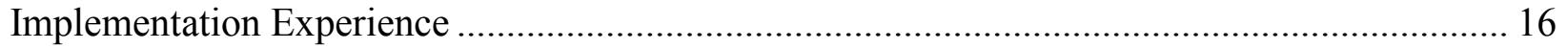

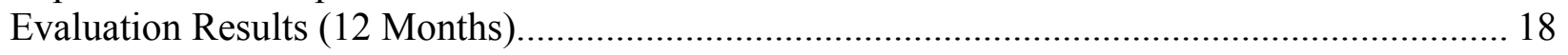

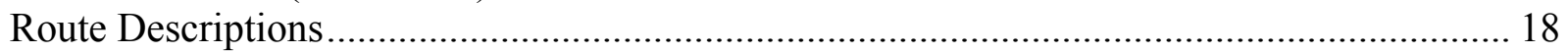

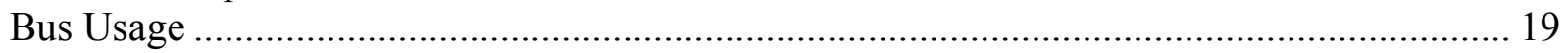

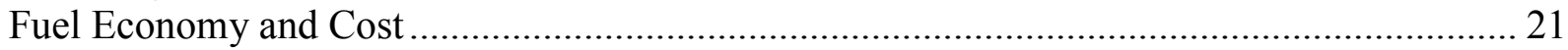

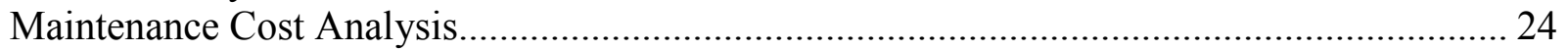

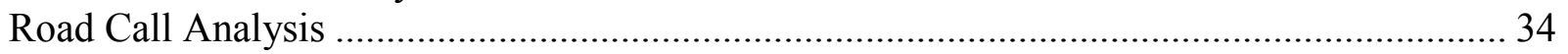

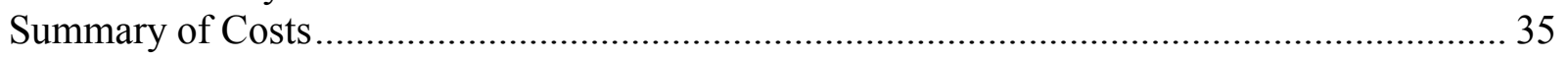

Laboratory Emissions Testing …………………………............................................. 36

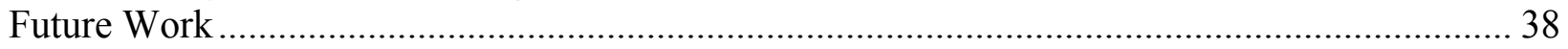

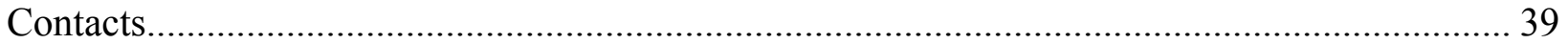

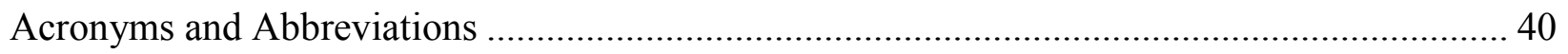

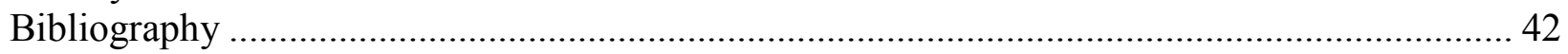

Appendix: Fleet Summary Statistics.................................................................................... 44 


\section{Executive Summary}

This is the final report to evaluate and compare new diesel and diesel hybrid electric articulated buses operated as part of the King County Metro Transit (KC Metro) fleet in Seattle, Washington. It concludes a 12-month evaluation at KC Metro. The evaluation was completed through the U.S. Department of Energy's (DOE) Advanced Vehicle Testing Activity (AVTA) by the National Renewable Energy Laboratory (NREL).

KC Metro operates bus-only transit service in the 2,134-square-mile Seattle/King County, Washington, area. Its fleet consists of 1,400 standard and articulated buses, trolley buses, and streetcars. KC Metro recently began using 235 new hybrid electric articulated buses that replace an older fleet of 236 dual-mode Breda articulated buses. The Breda buses were specially developed for use in the 1.3-mile Seattle downtown transit tunnel since its opening in 1990. This tunnel was built with light rail in mind but had been used only by the Breda dual-mode buses until the hybrid buses were introduced. The Breda dual-mode buses allowed zero-emission, fully electric propulsion operation inside the tunnel, and diesel engine propulsion outside the tunnel or when the buses were not connected to the electric catenary system. ${ }^{1}$

Both the diesel and diesel hybrid electric articulated buses at KC Metro were manufactured by New Flyer Industries. The hybrid buses include General Motors' (GM) Allison E 50 System parallel hybrid propulsion system. This fleet is the largest application of the GM Allison hybrid propulsion system to date.

\section{Project Design and Data Collection}

This evaluation focused on diesel and hybrid diesel buses selected from three of KC Metro's seven operating depots or bases (see Table ES-1). All 30 of the new diesel articulated buses currently operate from the Ryerson Base depot; they are identical to the hybrid buses except for the hybrid electric propulsion systems. Ten diesel buses were selected from Ryerson Base for detailed evaluation, and 10 hybrid buses were selected from Atlantic Base for comparison. The Ryerson diesel buses and the Atlantic hybrid buses have similar service and duty cyclesdowntown service at an average speed of $12.4 \mathrm{mph}$ for Ryerson and $11.6 \mathrm{mph}$ for Atlantic during the first six months of the evaluation period, and $12.3 \mathrm{mph}$ for Ryerson and $10.5 \mathrm{mph}$ for Atlantic during the second six months. This difference is attributed to route changes during the evaluation period. During the first six months of the demonstration, the hybrid buses were operating in the downtown transit tunnel, while during the second six months, the tunnel was closed and all buses drove the surface streets in downtown Seattle.

\footnotetext{
${ }^{1}$ A catenary system features electricity-carrying wires strung above a roadway. Buses and trolley vehicles can obtain access to electric power via poles that touch the catenary wires and provide electricity directly to the electric propulsion system in the bus. Many light rail systems also use a catenary system to provide the light rail vehicle with access to electricity and power for propulsion.
} 
Table ES-1. Summary of Evaluation Sites and Buses

\begin{tabular}{|l|c|c|c|}
\hline \multicolumn{1}{|c|}{ Topic } & Ryerson Base & Atlantic Base & South Base \\
\hline Number of Buses in Evaluation & 10 & 10 & 10 \\
\hline Bus Type & Diesel Only & Diesel Hybrid & Diesel Hybrid \\
\hline Evaluation Period & \multicolumn{3}{|c|}{ April 1, 2005-March 31, 2006 } \\
\hline
\end{tabular}

South Base hybrid buses (10 buses) were also selected for study, because that depot was the first to receive the new hybrid vehicles. South Base provided an opportunity to study an early implementation experience with the new technology at KC Metro, as well as to look at longer term potential maintenance and reliability issues that might arise in these oldest of the fleet buses. South Base has a higher operating average speed (19.5 $\mathrm{mph}$ for articulated buses in the first six months and then $18.1 \mathrm{mph}$ for the second six months) than the other two depots and should not be used in direct comparison. Data from this depot are therefore provided for reference only. The South Base evaluation results appear in gray type in this report as a reminder that the information is not intended to be directly compared with results from the other two depots.

\section{Hybrid and Diesel Buses}

The New Flyer diesel and diesel-hybrid articulated buses are identical except for the GM Allison $\mathrm{E}^{\mathrm{P}} 50$ parallel hybrid system. Both types of buses are equipped with Caterpillar (CAT) engines (C9-330 brake horsepower [bhp] maximum, 1,150 ft-lb torque and diesel particulate filters or DPF). The hybrid buses weigh approximately $1,100 \mathrm{lb}$ more than the diesels, but this does not make a difference in the number of passengers that can be carried because there is not enough standing space on either one to take the bus to the gross vehicle weight rating (GVWR).

The GM Allison $\mathrm{E}^{\mathrm{P}} 50$ parallel electric propulsion system has a drive unit that contains two motors and fits where a standard-size transmission would normally be placed in the bus. Each motor, which can also act as a generator, is capable of $75 \mathrm{~kW}$ continuous power and up to 150 $\mathrm{kW}$ peak power. This parallel hybrid propulsion system blends both the CAT engine power and the electric motor power to provide propulsion power. The energy storage system for the hybrid electric system consists of nickel metal hydride batteries, and the system operates with regenerative braking (i.e., braking energy is captured back through the motor/generator set and used later for propulsion along with the energy saved in the battery pack). The CAT engine is also capable of charging the energy storage system along with the regenerative braking energy.

\section{Implementation Experience}

New diesel and diesel-hybrid articulated buses were delivered to KC Metro at nearly the same time in May 2004. The 30 diesel buses were onsite and in service at Ryerson Base depot by July 2004. All 235 hybrid buses were delivered and put into service at Atlantic Base and South Base as well as two other depots by early December 2004.

$\mathrm{KC}$ Metro reported that there were no significant issues in placing the buses into service. It took only a few weeks after each bus was delivered to Seattle. As the new articulated buses were placed in service, the older Breda buses were retired. CAT used a local dealer for warranty support and in troubleshooting problems with these buses. New Flyer made one 
mechanic/technician available on site for KC Metro's needs. GM Allison also provided onsite technical support as needed. The buses are reportedly doing well; through March 2006, the 235 hybrid buses had operated for 13 million miles and the 30 diesel buses for 1.7 million miles.

The hybrid and diesel buses have been operating with only a few significant issues. There have been a few "fleet defects" and "campaigns" of warranty repairs as the manufacturers gained more experience with the KC Metro operation and environment, as well as specific design issues concerning the integration of the bus systems. A "fleet defect" is defined in the contract between the transit agency and the manufacturer as "failures of the same type occurring on multiple buses in an order." A "campaign" is a repair (typically covered under warranty) that is applied to an entire (or significant portion) of an order of buses. The following list summarizes some of the significant (major) campaigns for the propulsion system of these buses (some of which occurred during the evaluation period of this project):

1. Axle planetary snap rings $(8 / 2004)$

2. Allison software upgrade for issues with the inverter and CAT engine software changes $(9 / 2004)$

3. Proheat auxiliary coolant heater software change $(1 / 2005)$

4. Relocation of the DPF and change of the thermal blanket (2/2005)

5. Allison software upgrade for additional CAT engine software changes and $\mathrm{HUSH}^{\mathrm{TM}}$ mode hybrid thermal protection $(5 / 2005)$

6. Allison software upgrade for removing HUSH mode and a few software enhancements (10/2005) - removal of HUSH mode was at the request of KCM due to 2-year Transit Tunnel shutdown for remodeling. It will be re-activated again in 2007.

7. Voltage regulator retrofit $(11 / 2005)$

8. Replacement of turbocharger, heavier usage than expected, using titanium turbocharger parts $(1 / 2006)$.

The problem in item eight above, includes a warranty campaign for the CAT engine turbocharger. This problem, caused by heavier than expected usage, has resulted in a few turbocharger failures and, ultimately, associated DPF failures because of engine oil leaking into the exhaust through the damaged turbocharger. CAT has replaced the turbocharger compressor wheels with components made with titanium to alleviate this issue.

April 1, 2005, was chosen as a "clean point" for the evaluation because by then the major campaigns listed above were completed. The evaluation period selected for this report is April 2005 through March 2006.

\section{Evaluation Results}

The evaluation results presented in this report focus on the diesel buses operating from Ryerson Base and hybrid buses operating from Atlantic Base. These two depots were chosen for the evaluation because of their similar duty cycles, as noted earlier. South Base hybrid buses are included in the evaluation only to note some experiences in implementing the first hybrids at $\mathrm{KC}$ Metro. The duty cycle of the South Base hybrid buses was significantly different from those at the other two depots. It is not directly comparable and is included in this report for reference only. 
Table ES-2 summarizes the evaluation results presented in greater detail later in this report. Note that South Base hybrid data are presented but not included in the comparison discussion.

Regarding maintenance costs, mechanic labor was kept constant at $\$ 50$ per hour, which is not the actual labor rate at KC Metro. Data in the table column titled "Hybrid Difference" was calculated in this manner: (Result Hybrid Atlantic Base / Result Diesel Ryerson Base-1)* 100\% A positive result $(+)$ indicates that the hybrid Atlantic Base result was higher than the diesel Ryerson Base result. A negative result (-) indicates that the hybrid Atlantic Base result was lower than the diesel Ryerson Base result.

Table ES-2. Summary Evaluation Results (12-month evaluation period)

\begin{tabular}{|l|c|c|c|c|}
\hline \multicolumn{1}{|c|}{ Category } & $\begin{array}{c}\text { Diesel } \\
\text { Ryerson } \\
\text { Base }\end{array}$ & $\begin{array}{c}\text { Hybrid } \\
\text { Atlantic } \\
\text { Base }\end{array}$ & $\begin{array}{c}\text { Hybrid } \\
\text { Difference }\end{array}$ & $\begin{array}{c}\text { Hybrid } \\
\text { South Base }\end{array}$ \\
\hline Monthly Average Mileage per Bus & 2,949 & 3,096 & $\mathbf{+ 5 \%}$ & 3,957 \\
\hline Fuel Economy (mpg) & 2.50 & 3.17 & $\mathbf{+ 2 7 \%}$ & 3.75 \\
\hline Fuel Cost per Mile (\$) @\$1.98/gal) & 0.79 & 0.62 & $\mathbf{- 2 2 \%}$ & 0.53 \\
\hline Total Maintenance Cost per Mile (\$) & 0.46 & 0.44 & $\mathbf{- 4 \%}$ & 0.41 \\
\hline $\begin{array}{l}\text { Propulsion-Only Maintenance Cost } \\
\text { per Mile (\$) }\end{array}$ & 0.12 & 0.13 & $\mathbf{+ 8 \%}$ & 0.13 \\
\hline Total Operating Cost per Mile (\$) & 1.25 & 1.06 & $\mathbf{- 1 5 \%}$ & 0.94 \\
\hline Miles Between All Road calls & 5,896 & 4,954 & $\mathbf{- 1 6 \%}$ & 4,696 \\
\hline $\begin{array}{l}\text { Miles Between Propulsion Road } \\
\text { calls }\end{array}$ & 12,199 & 10,616 & $\mathbf{- 1 3 \%}$ & 8,547 \\
\hline
\end{tabular}

- Bus Usage - The diesel buses at Ryerson Base and hybrid buses at Atlantic Base had essentially the same monthly average mileage per bus; average mileage for the Atlantic Base hybrid buses was only $5 \%$ higher.

- Fuel Economy - The hybrid buses at Atlantic Base had on average 27\% higher fuel economy than the diesel buses at Ryerson Base. This difference ranged from $24 \%$ up to $30 \%$ during the evaluation period (0.67 mpg difference).

- Fuel Cost per Mile-The diesel buses at Ryerson Base used a biodiesel blend of 5\% biodiesel (B5) and 95\% ultra-low-sulfur diesel (ULSD) costing an average of \$2.01 per gallon during the evaluation period. The hybrid buses at Atlantic Base used only ULSD costing an average of $\$ 1.98$ per gallon during the evaluation period. The fuel cost and fuel economy combined resulted in a fuel cost per mile that was $22 \%$ lower (assuming only the ULSD cost of $\$ 1.98$ per gallon for both) for the hybrid buses at Atlantic Base than that of the diesel buses at Ryerson Base (\$0.17 per mile difference).

- Total Maintenance Cost per Mile-The hybrid buses at Atlantic Base and the diesel buses at Ryerson Base had similar total maintenance cost per mile; this cost for hybrid buses was $4 \%$ lower (\$0.02 per mile difference).

- Propulsion Only Maintenance Cost per Mile-The propulsion-related systems are transmission, nonlighting electrical (charging, cranking, and ignition), air intake, cooling, exhaust, fuel, engine, electric propulsion, and hydraulics. The hybrid buses at Atlantic Base and the diesel buses at Ryerson Base had similar cost per mile for this category with the hybrid buses being $8 \%$ higher ( $\$ 0.01$ per mile difference).

- Total Operating Cost per Mile-This category is the sum of the fuel cost per mile and the total maintenance cost per mile. Total operating costs for the hybrid buses at Atlantic 
Base were $15 \%$ lower than those of the diesel buses at Ryerson Base $(\$ 0.19$ per mile difference).

- Miles Between All Road Calls - The definition of road call is taken from the Federal Transit Administration (FTA) National Transit Database (NTD). A road call, or revenue vehicle system failure, is defined as a failure of an in-service bus that causes the bus to be replaced on its route or that causes a significant schedule delay. The hybrid buses at Atlantic Base had a $16 \%$ lower rate of miles between all road calls than that of the diesel buses at Ryerson Base.

- Miles Between Propulsion Road Calls - The rate for hybrid buses at Atlantic Base in this category was $13 \%$ lower than that of the diesel buses at Ryerson Base.

\section{Emissions Testing}

Two buses were tested at NREL's ReFUEL laboratory in Golden, Colorado, in May and June 2005. One bus (vehicle 2899) was from the conventional diesel fleet (from Ryerson Base Depot), and another bus (vehicle 2709) was from the hybrid fleet (one of the 235 hybrids ordered). Both vehicles were tested for fuel economy and emissions performance on identical cycles. Four cycles were tested to determine the variability of fuel economy and emissions: Central Business District 14 (CBD), Manhattan, the Orange County Transit Authority (OCTA), and a custom cycle made up of various King County runs (KCM). Each vehicle was tested multiple times on each run to ensure some level of statistical accuracy. Fuel economy, carbon dioxide $\left(\mathrm{CO}_{2}\right)$, carbon monoxide $(\mathrm{CO})$, nitrogen oxides $(\mathrm{NOx})$, and particulate matter (PM) were measured. Differences in measurements between the hybrid and the conventional bus are shown in Table ES-3.

Table ES-3. Hybrid Bus vs. Conventional Bus Test Results

\begin{tabular}{|l|c|c|c|c|c|}
\hline & & & & $\begin{array}{c}\text { In-use: } \\
\text { Atlantic Base }\end{array}$ \\
\hline Fuel Economy (mpg, \% increase) & $74.6 \%$ & $50.6 \%$ & $48.3 \%$ & $30.3 \%$ & $26.8 \%$ \\
\hline Fuel Consumption (gram/mi, \% reduction) & $42.9 \%$ & $33.7 \%$ & $32.8 \%$ & $23.4 \%$ & $21.2 \%$ \\
\hline NOx (gpm, \% reduction) & $38.7 \%$ & $28.6 \%$ & $26.6 \%$ & $17.8 \%$ & - \\
\hline PM (gpm, \% reduction) & $92.6 \%$ & $50.8 \%$ & $97.1 \%$ & Ns & - \\
\hline CO (gpm, \% reduction) & ns & $32.0 \%$ & $48.0 \%$ & $59.5 \%$ & - \\
\hline THC (gpm, \% reduction) & ns & ns & $75.2 \%$ & $56.3 \%$ & - \\
\hline
\end{tabular}

Note: $\mathrm{gpm}$ = gallons per mile; $\mathrm{mpg}=$ miles per gallon; $\mathrm{ns}=$ not statistically significant at $95 \%$ confidence level or not enough data to determine; THC = total hydrocarbon.

Detailed information on this testing is available later in this report. It will also be available online in the report KCM Transit Emissions (www.nrel.gov/vehiclesandfuels/ahhps/publications.html).

\section{Future Work}

All the new diesel and hybrid articulated buses ordered from New Flyer have been in service since at least December 2004. This final evaluation report provides results from a 12-month evaluation period. The first six months covered in this report included operation of the hybrid buses in the downtown transit tunnel. The second six months of operation were with the transit tunnel closed. The HUSH mode feature of the hybrid buses was deactivated via software in 
October 2005 to coincide with the closure of the tunnel. The tunnel is planned to reopen in 2007 and HUSH mode will be reactivated at that time.

KC Metro has just issued an RFP to add 20 more hybrid buses to its fleet. The RFP also includes an additional 60-month supply option for up to 340 more hybrid and conventional powered articulated low floor buses. 


\section{Changes and Additions Since the Interim Report}

This final evaluation report updates the King County Metro Transit Hybrid Articulated Buses: Interim Evaluation Results, April 2006, NREL/TP-540-39742. The interim reported covered six months of a 12-month evaluation (April 2005 through September 2005) of the New Flyer articulated 60-foot hybrid and diesel buses at King County Metro Transit (KC Metro). This report completes the full 12 months of data evaluation-April 2005 through March 2006 and includes updates in diesel fuel costs, fuel economy, and maintenance information. Extensive effort has been made to complete the evaluation of warranty repairs and costs, which are presented separate from the maintenance cost analysis.

\section{Overview}

This report includes the results of an evaluation of new diesel hybrid electric buses featuring General Motors (GM) Allison E ${ }^{\mathrm{P}} 50$ System parallel hybrid propulsion system and standard diesel articulated buses from New Flyer Industries. The buses operate in the KC Metro fleet in Seattle, Washington. The evaluation was completed through the U.S. Department of Energy's (DOE) Advanced Vehicle Testing Activity (AVTA) by the National Renewable Energy Laboratory (NREL), which has been tracking and evaluating new propulsion systems in transit buses and trucks for more than 10 years using a well-established and documented evaluation protocol. ${ }^{2}$

\section{Advanced Vehicle Testing Activity}

The role of AVTA is to bridge the gap between research and development (R\&D) and the commercial availability of advanced vehicle technologies that reduce U.S. petroleum consumption. AVTA supports DOE's FreedomCAR \& Vehicle Technologies Program by evaluating the performance and durability of alternative fuel and advanced technology vehicles and assessing the performance of these vehicles in fleet applications.

The main objective of AVTA projects is to provide comprehensive, unbiased evaluations of advanced technologies. Data collected and analyzed include the operation, maintenance, performance, safety, cost, and emissions characteristics of advanced technology fleets and comparable conventional technology fleets operating at the same site. By comparing available advanced and conventional technology vehicles, AVTA evaluations help fleet owners and operators make informed purchasing decisions.

The AVTA team conducts medium- and heavy-duty vehicle evaluations. Hybrid electric transit buses are one of the advanced vehicle choices available today. The evaluation team has conducted or is in the process of conducting several evaluations of advanced propulsion vehicles (see Table 1). For information on other evaluations, visit www.nrel.gov/vehiclesandfuels/fleettest.

\footnotetext{
${ }^{2}$ General Evaluation Plan, Fleet Test and Evaluation Projects, NREL/BR-540-32392, National Renewable Energy Laboratory, July 2002; www.nrel.gov/vehiclesandfuels/fleettest/pdfs/32392.pdf.
} 
Table 1. AVTA Heavy Vehicle Evaluations

\begin{tabular}{|l|l|l|l|l|}
\hline \multicolumn{1}{|c|}{ Fleet } & \multicolumn{1}{c|}{ Location } & \multicolumn{1}{c|}{ Vehicle } & \multicolumn{1}{c|}{ Technology } & \multicolumn{1}{c|}{ Evaluation Status } \\
\hline $\begin{array}{l}\text { King County } \\
\text { Metro }\end{array}$ & Seattle, WA & $\begin{array}{l}\text { New Flyer 60-ft } \\
\text { articulated transit } \\
\text { bus }\end{array}$ & $\begin{array}{l}\text { Parallel hybrid, GM-Allison } \\
\text { EP50 System (diesel) }\end{array}$ & $\begin{array}{l}\text { In progress; interim } \\
\text { results reported here }\end{array}$ \\
\hline $\begin{array}{l}\text { New York City } \\
\text { Transit }\end{array}$ & $\begin{array}{l}\text { Manhattan, } \\
\text { Brooklyn, Bronx, } \\
\text { Queens, NY }\end{array}$ & $\begin{array}{l}\text { Orion VII 40-ft } \\
\text { transit bus }\end{array}$ & $\begin{array}{l}\text { Series hybrid, BAE Systems } \\
\text { HybriDrive propulsion system } \\
\text { (diesel), two generations; } \\
\text { DDC S50G CNG engines }\end{array}$ & $\begin{array}{l}\text { Final results for the } \\
\text { order of 125 hybrid and } \\
\text { CNG reported in } \\
\text { August 2006 }\end{array}$ \\
\hline $\begin{array}{l}\text { IndyGo } \\
\text { Knoxville } \\
\text { Area Transit }\end{array}$ & Knoxville, TN & Ebus 22-ft bus & $\begin{array}{l}\text { Series hybrid, Capstone } \\
\text { MicroTurbine (diesel) }\end{array}$ & Completed in 2005 \\
\hline & & MicroTurbine (propane) & Completed in 2005 \\
\hline Norcal & San Francisco, CA & $\begin{array}{l}\text { Peterbilt/378, Class } \\
8 \text { truck }\end{array}$ & $\begin{array}{l}\text { Cummins Westport ISXG } \\
\text { high-pressure direct injection } \\
\text { LNG and diesel }\end{array}$ & Completed in 2004 \\
\hline
\end{tabular}

Note: $C N G$ = compressed natural gas; $L N G$ = liquefied natural gas

\section{Host Site Profile-KC Metro Transit}

KC Metro (http://transit.metrokc.gov) operates bus-only transit service in the 2,134-square-mile Seattle/King County, Washington, area. KC Metro operates a fleet of about 1,400 vehicles, standard and articulated buses, trolley buses, and streetcars that make a total of about 100 million trips annually. KC Metro also operates the largest publicly owned vanpool program in the country-more than 600 vans in the program make more than 2.9 million trips per year.

Like most large transit agencies, $\mathrm{KC}$ Metro has been committed to supplying environmentally responsible transportation through several initiatives, including the following:

- Retrofits of the existing diesel bus fleet with diesel particulate filters (DPF) and the use of ultra-low sulfur diesel (ULSD) fuel. ULSD is a specially refined fuel with significantly lower sulfur content (less than 15 parts per million) than regular highway diesel.

- Continued use of zero-emission electric trolley buses to supply clean and quiet transportation on some of the busiest routes.

- Use of biodiesel blends at B5 levels (or 5\% biodiesel by volume in diesel fuel) at two operating depots (Bellevue and Ryerson bases).

- Use of new hybrid electric articulated buses from New Flyer and GM Allison.

KC Metro also provides bus service in King County under contract to Sound Transit. Sound Transit is a regional transit operator serving multiple counties. KC Metro and Sound Transit are cooperating to install light rail in the Seattle downtown transit tunnel, as discussed later in this report.

\section{Description of the KC Metro Hybrid Transit Bus Project}

One of the latest transit improvements introduced at KC Metro is the use of new hybrid electric articulated buses to replace a fleet of dual-mode Breda articulated buses. The Breda buses were specially developed for use in the Seattle downtown transit tunnel (see the map in Figure 1) since it opened in 1990. The Breda dual-mode buses allowed zero-emission electric propulsion 
operation in the tunnel and diesel engine propulsion outside the tunnel or when the buses are not connected to the electric catenary system.

In a catenary system, electricity-carrying wires strung above a roadway provide buses and trolley vehicles with electric power. Poles touch the catenary wires and provide electricity directly to the bus's electric propulsion system. Many light rail systems also use a catenary system to provide the light rail vehicle with access to electricity and power for propulsion.

Experiences with the Breda Dual-Mode Buses. KC Metro has been operating a fleet of 236 Breda dual-mode buses (one is shown in Figure 2) that are at the end of their useful life-more than 14 years, in contrast to their 12-year expected lifetime. The 1.3-mile Seattle downtown tunnel was built with light rail in mind but had been used exclusively by the Breda dual-mode buses until the hybrid buses were placed in service. The bus tunnel was built under $3^{\text {rd }}$ Avenue through the downtown area. This has helped to reduce congestion in downtown Seattle and helps KC Metro to keep buses on schedule with this exclusive right-of-way. One of the tunnel stations is shown in Figure 3.

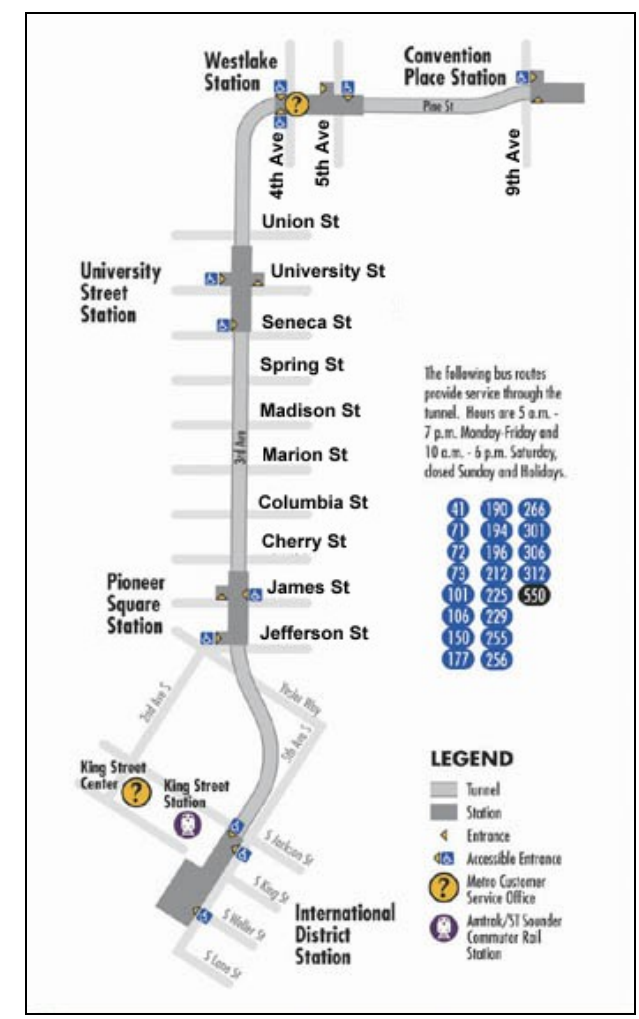

Figure 1. Seattle Downtown Transit Tunnel 


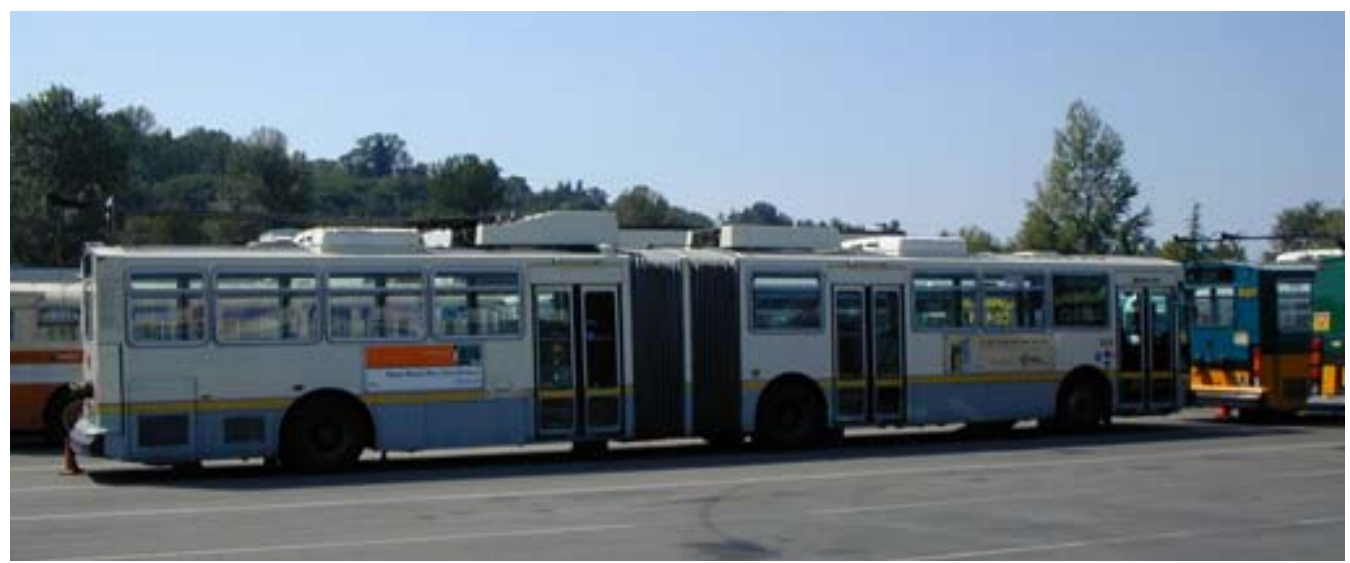

Figure 2. Breda Dual-Mode Bus in Yard

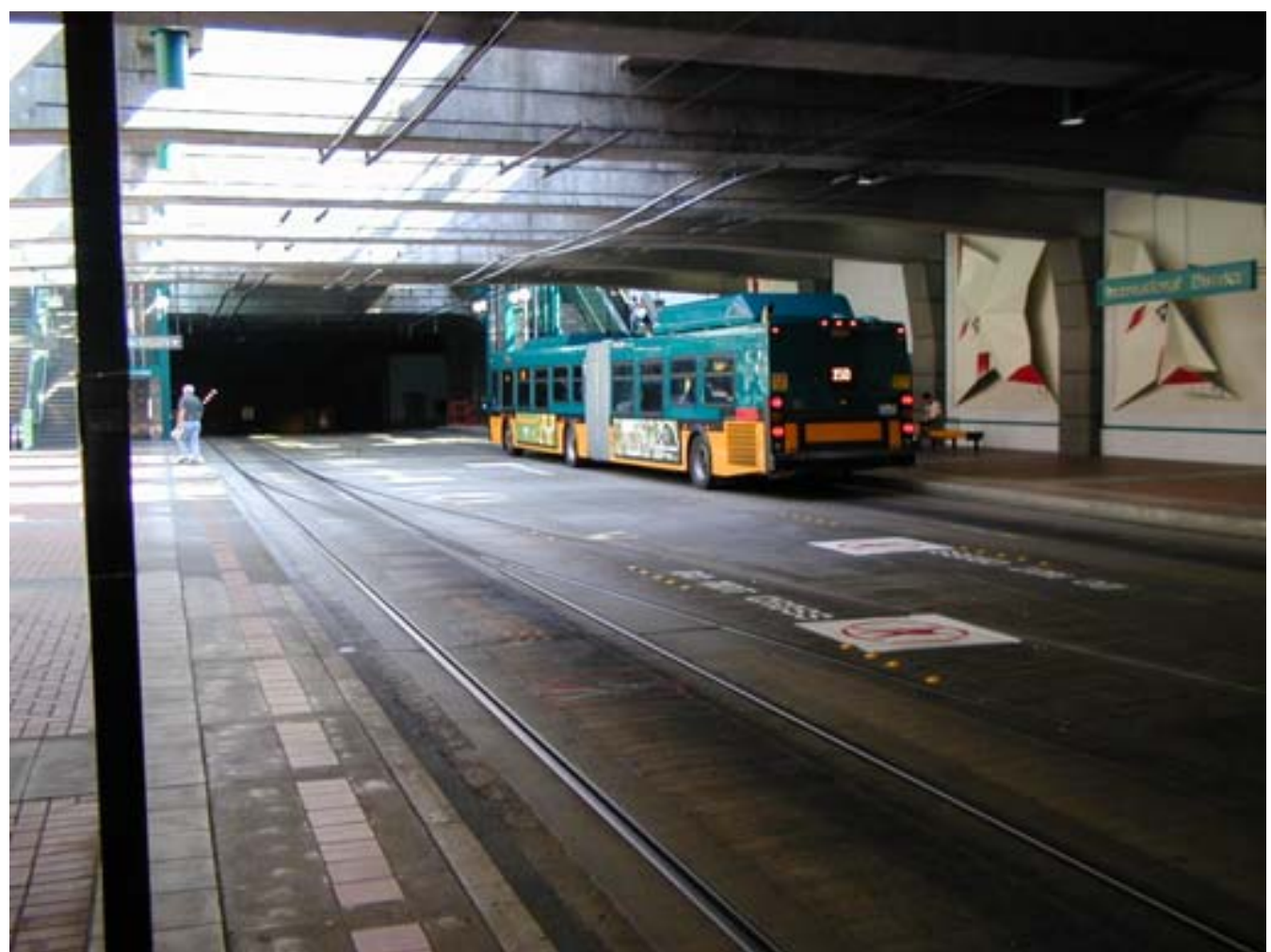

Figure 3. Hybrid Bus in Seattle Downtown Tunnel at International Station

The Breda dual-mode buses (Figure 2) were originally a unique application. This 60-foot (ft) articulated bus has two operating modes, a diesel engine mechanical power train, and an electric propulsion system powered by a catenary system. While it is in the tunnel, the bus is propelled by the electric drive system via the catenary poles for electricity and power. When the bus is outside the tunnel, the catenary poles are retracted, and the diesel engine drives a separate mechanical drive train to operate the bus. Other North American cities that have used a similar type of dual-mode bus include Vancouver, Dayton, and Boston.

$\mathrm{KC}$ Metro has had a somewhat difficult and expensive experience with the Breda dual-mode buses. In 1988, the Breda buses were purchased for $\$ 450,000$ each, and the Italian manufacturer 
did not provide much onsite support. Troubleshooting and maintaining the Breda buses required a significant amount of time and dedication on the part of the KC Metro staff. Some operating problems with the Breda dual-mode buses required KC Metro staff to come up with unique solutions so the bus's operation would be acceptably reliable. One of the major issues was the unavailability of replacement parts. Some of these parts were available only through the manufacturer, who used small suppliers in Italy. In some cases, these parts had to be purchased a year in advance and in large quantities. Some parts were therefore analyzed and redesigned so that local U.S. shops could be used for procurements.

In KC Metro's experience through 2004, the last full year of the Breda fleet's operation, about $25 \%$ of the fleet needed to have an engine rebuilt each year and $33 \%$ needed to have a transmission rebuilt each year, on average. These measures were causing significant increases in maintenance costs. The engine in the Breda buses was an older DDC 6V92 diesel engine that needed an emissions waiver to be operated because it was not certified at the required 310-hp level required for an articulated bus.

The use of the Breda buses was discontinued in early 2005 to reduce operating and maintenance costs. The last date of operation for those buses was January 24, 2005; however, 59 of the buses were refurbished as trolley buses (electric only) and were put back in service on the catenary system (one is shown in Figure 4). Many of the remaining Breda dual-mode buses will be used for parts to help keep the 59 Breda trolley buses operating.

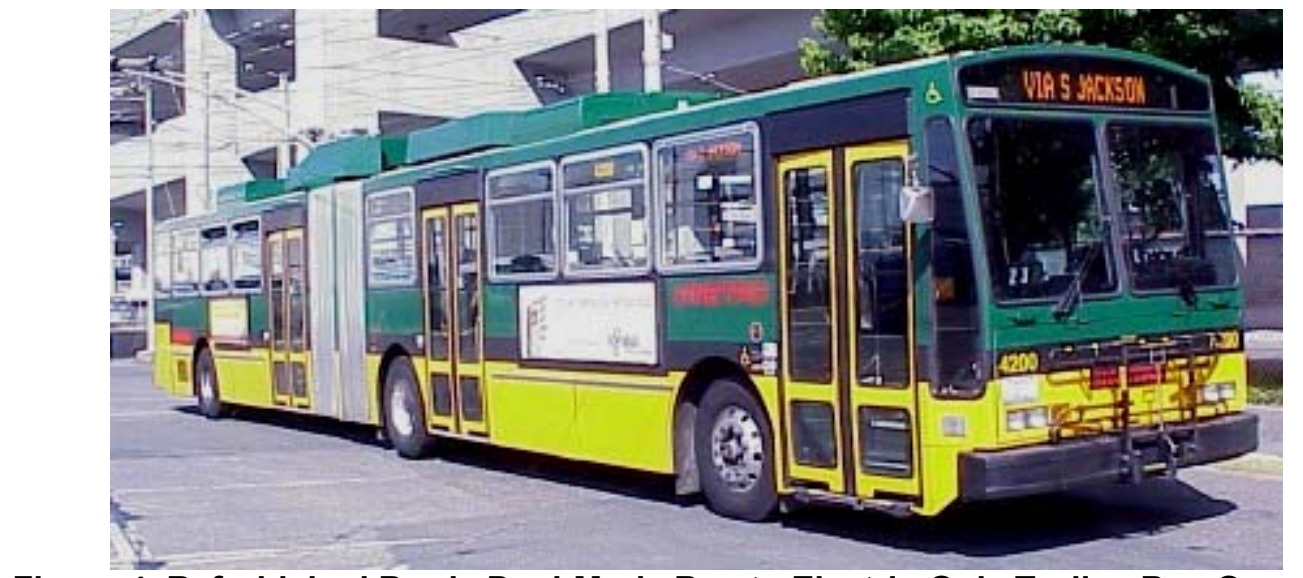

Figure 4. Refurbished Breda Dual-Mode Bus to Electric-Only Trolley-Bus Operation

Investigation of the GM Allison Hybrid. At around the same time that the transit company began investigating replacements for the Breda dual-mode buses, KC Metro and Sound Transit were putting plans together to add light rail to the downtown tunnel operation. The light rail operation requires a 1,500 VDC (volts, direct current) catenary, and the dual-mode bus catenary is $700 \mathrm{VDC}$. If both the light rail and dual-mode bus fleet were to operate in the tunnel at the same time, both catenary systems would need to coexist in the tunnel. The company decided that there would be a significant benefit to removing the 700 VDC catenary system and discontinue the use of the dual-mode buses.

KC Metro looked into replacing the Breda dual-mode buses not just because of their age but also because those buses had always been expensive to operate and maintain. New dual-mode buses 
were expected to be an expensive purchase; for example, Boston recently purchased new dualmode buses at an average cost of $\$ 1.6$ million each. However, new dual-mode buses were no longer desirable to KC Metro because of the light rail situation in the tunnel. A replacement bus technology needed to be found that could meet the following objectives:

1. Operate in the tunnel with low tailpipe and noise emissions, preferably without the catenary system

2. Have significantly reduced operation and maintenance costs, compared with those of the Breda dual-mode buses

3. Ideally, operate on routes other than the tunnel route.

The search for a bus technology that would replace the dual-mode buses started in early 2000, around the same time that a division of GM known as Allison Electric Drives (www.allisontransmission.com/product/electricdrive/index.jsp) began investigating potential test fleets for its new hybrid bus propulsion system. After viewing a conference presentation by Allison, KC Metro and Allison began discussions. Allison demonstrated its technology at KC Metro using a 40-ft bus with a trailer to simulate the operation of an articulated bus.

The result of this testing was enough to move $\mathrm{KC}$ Metro to the next stage, which was to demonstrate the technology by purchasing one bus (number 2599). New Flyer Industries (www.newflyer.com) was the only builder to respond to KC Metro's request for proposals (RFP) for the one hybrid articulated demonstrator bus. Bus number 2599 was received in October 2002 and immediately put into service shadowing another in-service bus. The goal was to put a year's worth of operation on the bus as soon as possible. It was loaded to $130 \%$ seated load weight and operated in mock revenue service (known as "shadow service") from November 2002 through February 2003 for 7 days a week from noon to 8 a.m. the next morning. The bus was serviced between 8 a.m. and noon each day. It operated a total of 37,000 miles during the four-month testing period. This test was documented in a GM Allison video, "Allison Electric Drives King County Seattle Phases 1 \& 2 Test."

This first hybrid articulated bus used a Cummins engine (ISL-330 hp, 8.9 liter). In December 2002, Cummins notified KC Metro that it could not meet the emissions requirement for a model year 2004 bus with a 330-hp engine and pulled out of the project. Soon afterward, Caterpillar (CAT) expressed an interest in providing high-horsepower engines for the transit bus industry. CAT had a C9 (8.8 liter) diesel engine that was already certified for emissions at $330 \mathrm{hp}$ for a bus model year 2004 engine. This was the exact size needed for the hybrid articulated bus. Therefore, the project team - which included New Flyer, GM Allison, and KC Metro-switched to CAT as the engine supplier at that time.

Purchase of 235 New Flyer/GM Allison Hybrid Buses. In April 2003, KC Metro released an RFP for 265 buses - including 213 hybrid 60-ft articulated buses for KC Metro, 22 hybrid 60-ft articulated buses for Sound Transit, plus 30 conventional diesel 60-ft articulated buses for KC Metro. The RFP included only standard performance criteria, because KC Metro wanted to allow the manufacturer some flexibility, and the CAT engine was specified in the RFP as a powerplant acceptable to KC Metro just before release. A contract was signed in October 2003 with New Flyer that included the GM Allison electric drive and CAT C9 engine. The intent of this order was to replace the Breda fleet of buses entirely; the 235 new hybrid buses plus the demonstrator 
replaced the 236 Breda dual-mode buses. The new hybrid articulated buses cost $\$ 645,000$ each. The diesel articulated buses, which were essentially identical to the hybrid buses without the electric propulsion system, cost $\$ 445,000$ each.

The new hybrid and diesel articulated buses (shown in Figures 5 and 6) were delivered to five operating bases at $\mathrm{KC}$ Metro in the following order:

1. South Base -75 hybrid buses

2. Ryerson Base-30 diesel buses

3. East Base-38 hybrid buses

4. North Base-48 hybrid buses

5. Atlantic Base-52 hybrid buses

KC Metro took final delivery of all the new hybrid articulated buses in early December 2004.

Expectations of the Hybrid Bus Project. KC Metro and the hybrid bus project team expected significant cost savings for the hybrid buses when compared with the Breda dual-mode buses for operation and maintenance. The reasons that KC Metro implemented this hybrid project were as follows:

- The buses are capable of tunnel operation.

- Maintenance costs will be lower (when compared with costs for the Breda buses).

- Fuel economy will increase (when compared with that of the Breda buses; hybrid electric technology reduces emissions further when compared with the Breda buses by converting energy that is normally wasted in braking into electricity used to help the bus accelerate, i.e., regenerative braking).

- Intervals between brake relinings should be longer ( 70,000 miles).

- There is potential to extend the engine oil drain interval (based on oil sampling, the Cummins engine in the demonstration bus extended the oil drain interval from 6,000 miles to 24,000 miles with no problems; the CAT engine was expected also to extend this interval, and a sampling program was planned to determine the appropriate interval; the company is also looking at using a synthetic engine oil).

- The engines of the hybrid buses are expected to last the entire 12-year life of the bus.

- The drive train is not expected to require fluid changes during its lifetime.

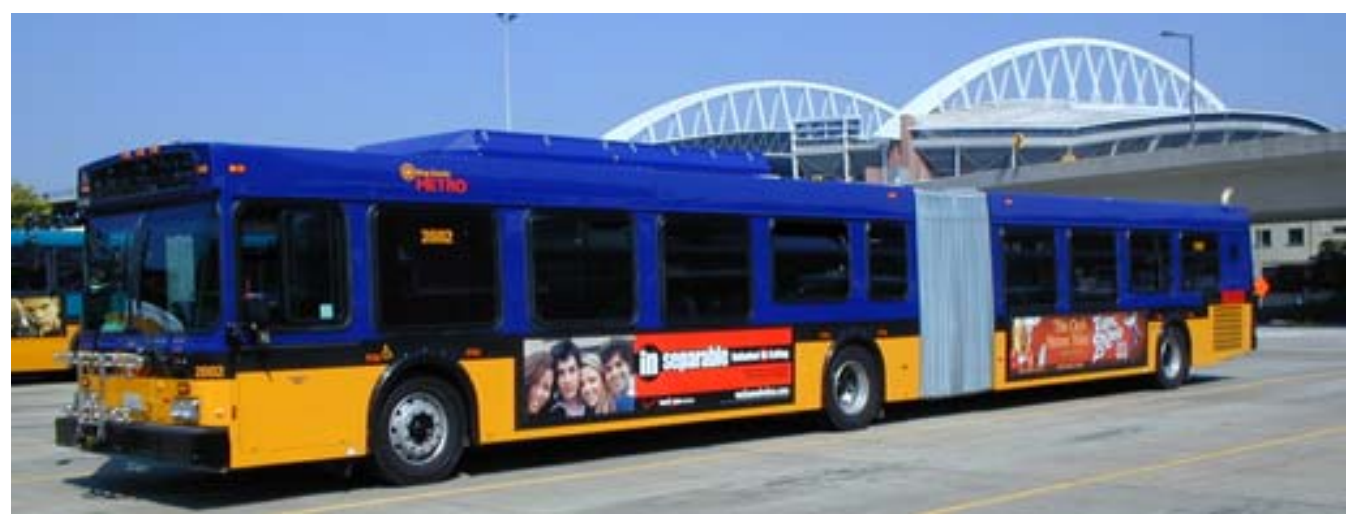

Figure 5. New Flyer 60-Ft Articulated Diesel Bus at Ryerson Base 


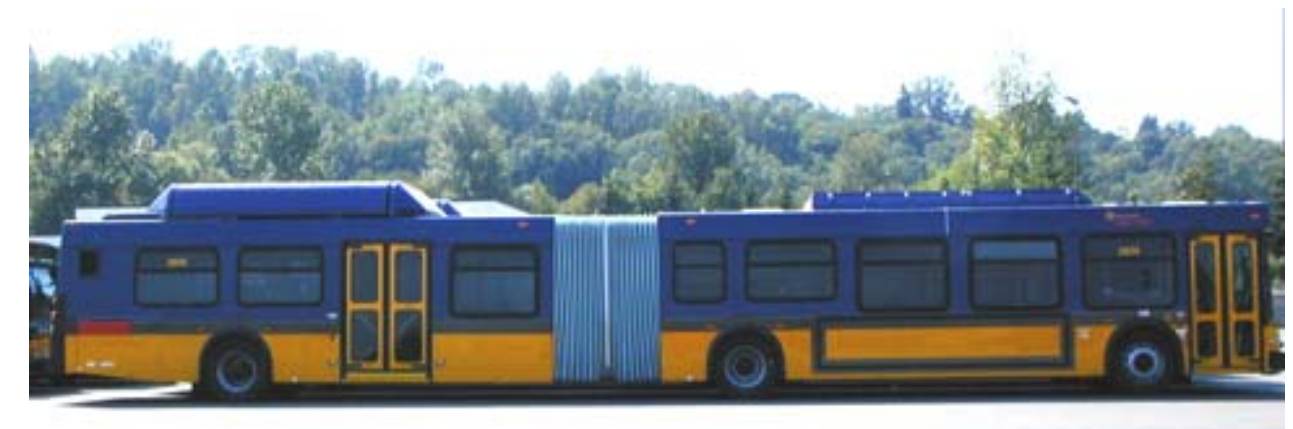

Figure 6. New Flyer 60-Ft Articulated Hybrid Bus

\section{Project Design and Data Collection}

AVTA evaluation projects focus on using a standardized process for data collection and analysis, communicating results clearly, and providing an accurate and complete evaluation. The information in this report utilized data based on 10 selected new baseline diesel buses operating at Ryerson Base and 10 new hybrid buses operating at Atlantic Base as well as 10 new hybrid buses at South Base. The Ryerson and South Base buses went into service about the same time (June-July 2004) and the Atlantic Base buses went into service around November 2004. This evaluation omits warranty costs from the maintenance cost analyses; the warranty costs are analyzed separately.

South Base was the first depot to receive hybrid buses, and this provided an opportunity to evaluate the early operation of the hybrid buses at KC Metro as well as to look at the longer term operation of this hybrid technology for potential maintenance and reliability issues. Ryerson Base was the only depot with the diesel version of the new articulated buses, and the hybrid buses at Atlantic Base were selected for evaluation because of the similar operating cycles of Ryerson and Atlantic. Therefore, all cost and fuel economy comparisons in this report focus on the buses at the Ryerson and Atlantic bases, because they allow an 'apples-to-apples' comparison. South Base was used for reference only. The evaluation strategy is discussed again in the section on evaluation results.

All the articulated buses at the three depots were dispatched randomly on all routes designated for articulated bus operation. There were no restrictions on the diesel or hybrid articulated buses.

The data collection activity was designed to disrupt $\mathrm{KC}$ Metro operations as little as possible. Data were sent electronically from KC Metro to Battelle for analysis. Data collected for the study included the following (vehicle, dates, and odometer readings were recorded for each):

- Fluids - fuel, oil, coolant, transmission, and any others

- Maintenance-repair history, including all work orders

- Warranty - all warranty costs from KC Metro, New Flyer, GM Allison, and CAT

- Road calls - from the Work Order Cost Report

- Route assignment.

Fleet-level summary data for the 30 new diesel and 235 new hybrid articulated buses were also collected, including mileage accumulations and road calls. The study was designed to include 
tracking of safety incidents that affected the vehicles or occurred at KC Metro facilities; however, no safety incidents were reported during the data collection period.

\section{Vehicle System Descriptions}

Table 2 summarizes the vehicle system descriptions for the diesel and hybrid articulated groups of buses studied. The diesel and hybrid articulated buses are essentially identical except for the hybrid propulsion system. The hybrid buses weigh approximately 1,100 lb more than the diesels; this does not make a difference in the number of passengers because there is not enough standing space to take the bus to the gross vehicle weight rating (GVWR). Table 3 provides some details about the GM Allison $\mathrm{E}^{\mathrm{P}} 50$ parallel electric propulsion system.

Table 2. Vehicle System Descriptions

\begin{tabular}{|c|c|c|c|}
\hline Vehicle System & Diesel & Hybrid & Hybrid \\
\hline Operating Location & Ryerson & Atlantic & South \\
\hline Number of Buses & 10 & 10 & 10 \\
\hline $\begin{array}{l}\text { Bus Manufacturer and } \\
\text { Model }\end{array}$ & New Flyer D60LF & New Flyer DE60LF & New Flyer DE60LF \\
\hline Model Year & 2004 & 2004 & 2004 \\
\hline Length/Width/Height & $60.7 \mathrm{ft} / 102 \mathrm{in} / 132 \mathrm{in}$ & $60.7 \mathrm{ft} / 102 \mathrm{in} / 132 \mathrm{in}$ & $60.7 \mathrm{ft} / 102 \mathrm{in} / 132 \mathrm{in}$ \\
\hline GVWR/Curb Weight & $66,790 \mathrm{lb} / 43,500 \mathrm{lb}$ & $66,790 \mathrm{lb} / 44,600 \mathrm{lb}$ & $66,790 \mathrm{lb} / 44,600 \mathrm{lb}$ \\
\hline Passenger Capacity & $\begin{array}{c}58 \text { Seated } \\
\text { Standees Space Limited }\end{array}$ & $\begin{array}{c}58 \text { Seated } \\
\text { Standees Space Limited }\end{array}$ & $\begin{array}{c}58 \text { Seated } \\
\text { Standees Space Limited }\end{array}$ \\
\hline $\begin{array}{l}\text { Engine Manufacturer } \\
\text { and Model }\end{array}$ & Caterpillar C9 (8.8L) & Caterpillar C9 (8.8L) & Caterpillar C9 (8.8L) \\
\hline Rated Horsepower & 330 hp @ 2100 rpm & 330 hp @ 2100 rpm & 330 hp @ 2100 rpm \\
\hline Rated Torque & 1150 ft-lb @ 1400 rpm & 1150 ft-lb @ 1400 rpm & 1150 ft-lb @ 1400 rpm \\
\hline Emissions Equipment & Engelhard DPX & Engelhard DPX & Engelhard DPX \\
\hline $\begin{array}{l}\text { Retarder/Regenerative } \\
\text { Braking }\end{array}$ & Retarder & Regenerative Braking & Regenerative Braking \\
\hline Fuel Capacity & 125 gallons & 125 gallons & 125 gallons \\
\hline Bus Purchase Cost & $\$ 445,000$ & $\$ 645,000$ & $\$ 645,000$ \\
\hline
\end{tabular}

Table 3. Hybrid Propulsion Systems

\begin{tabular}{|l|l|}
\hline \multicolumn{1}{|c|}{ Hybrid-Related System } & \multicolumn{1}{c|}{ Hybrid Buses } \\
\hline Manufacturer/Model & GM Allison Electric Drives E 50 \\
\hline Hybrid Type & Parallel \\
\hline Motor/Generator & $75 \mathrm{~kW}$ continuous, 150 kW peak \\
\hline Drive Unit & $\mathrm{E}^{\mathrm{V} 50}$ Drive: $246 \mathrm{~kW}$ input rating, 1,050 ft-lb torque \\
\hline Controls & Allison (proprietary) \\
\hline Energy Storage & $\begin{array}{l}\text { Nickel metal hydride batteries, 6 modules, 600 VDC } \\
\text { (nominal) }\end{array}$ \\
\hline Inverter & $\begin{array}{l}\text { Dual Power Inverter Module (DPIM), 430-900 VDC, } \\
160 \mathrm{~kW} \text { continuous 3-phase AC }\end{array}$ \\
\hline Regenerative Braking & Yes \\
\hline
\end{tabular}

Caterpillar C9 Engine. The diesel engine used in each of the new diesel and hybrid articulated buses is the Caterpillar (CAT) C9 engine (see https://ohe.cat.com/cda/layout? $\mathrm{m}=37285 \& \mathrm{x}=7$ ). The U.S. Environmental Protection Agency (EPA) engine emissions certification data results for the CAT C9 engine are shown in Table 4. 
Table 4. EPA Emissions Certification Levels for Model Year 2004 (g/bhp-hr)

\begin{tabular}{|l|l|c|c|c|c|}
\hline \multicolumn{1}{|c|}{ Model Year } & \multicolumn{1}{|c|}{ Fuel } & HC + NOx & CO & PM & Engine Family \\
\hline $\begin{array}{l}\text { Certification } \\
\text { Levels }\end{array}$ & Diesel & 2.4 & 15.5 & 0.05 & All \\
\hline 2004 CAT C9 & Diesel & 2.4 & 0.6 & 0.00 & 4 CPXH0537H3K \\
\hline
\end{tabular}

GM Allison Electric Drives $\mathbf{E}^{\mathrm{P}} \mathbf{5 0}$. The parallel hybrid propulsion system blends both the CAT engine power and the electric motor power to provide propulsion power. The energy storage system supplies electricity to the motor and stores the energy generated during regenerative braking events. The system is also recharged via the diesel engine and generator in the drive unit. Figure 7 provides some details about the operation of this hybrid propulsion system. Figure 8 shows a static display of the electric propulsion drive unit, which is designed to replace a standard transmission and to go where a standard transmission is usually placed. Figure 9 shows the Dual Power Inverter Module (DPIM) with the cover open. Each bus has one DPIM that is used to convert electrical energy into alternating current (AC) and direct current (DC) for storage and use.

This electric propulsion system has several advantages over conventional propulsion systems. It allows the engine to operate more efficiently and allows for regenerative braking, both of which increase fuel economy. For example, electric power dominates when the bus accelerates from a stop, helping to eliminate the exhaust cloud typically produced by the higher transient load on the engines in conventional buses. The added electric power also allows the bus to accelerate faster, which is beneficial in city driving.

The hybrid buses have a feature unique to KC Metro's operation: HUSH ${ }^{\mathrm{TM}}$ mode. HUSH mode fills the need for an operating mode to minimize noise and engine emissions while a bus is in Seattle's downtown transit tunnel. The hybrid buses operate in an electric-only mode in the station areas of the tunnel and in a reduced engine power mode in between stations. 


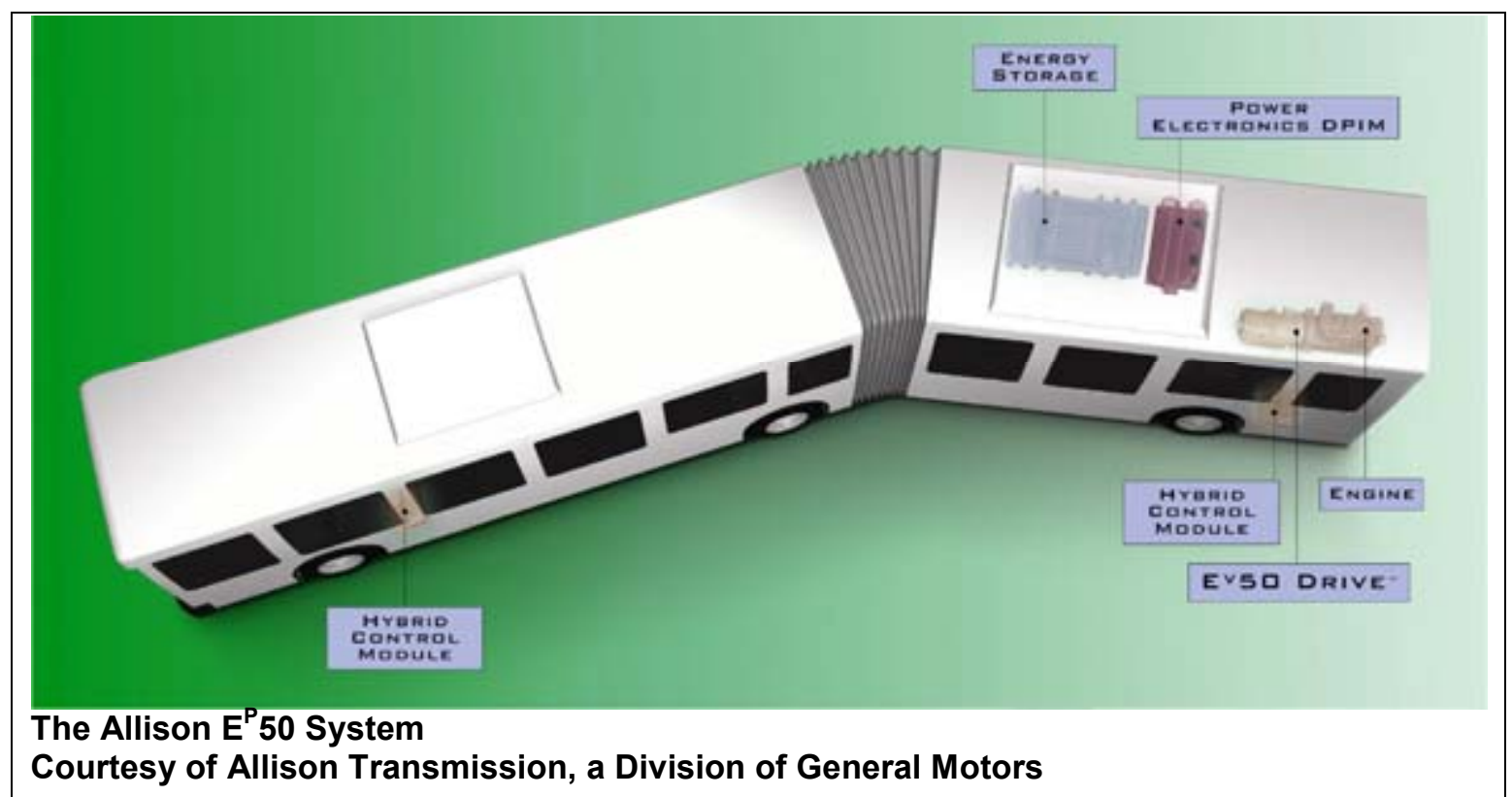

The energy storage system supplies electricity to the $\mathrm{E}^{\mathrm{V}} 50$ Drive's electric motors. It stores electricity during normal operation and regenerative braking.

The dual power inverter module converts electricity into alternating or direct current. This enables transfer, storage, and use of energy between the $E^{\vee} 50$ Drive, which uses and produces alternating current, and the energy storage system, which can only store direct current.

The hybrid control modules process information from system components and driver inputs. They control vehicle propulsion and energy production and include diagnostic and reprogramming features.

The engine produces power, which is used to propel the bus and to produce electricity that is stored in the energy storage system.

The $\mathbf{E}^{\mathbf{V}} \mathbf{5 0}$ Drive converts electricity from the energy storage system into power to propel the bus, and it converts power from the engine and regenerative braking into electricity that is stored in the energy storage system.

Figure 7. GM Allison E 50 System Description

During the first six months of the evaluation, KC Metro's operation in the 1.3 mile long downtown tunnel posed a unique challenge for GM Allison engineers. KC Metro wanted the hybrid buses to be able to operate in the tunnel only on electric power, without any engine operation, to reduce tailpipe and noise emissions in the tunnel. The Allison engineers determined that the hybrid buses could operate in the tunnel on battery power only, but this would severely reduce battery life, so a compromise was needed. 


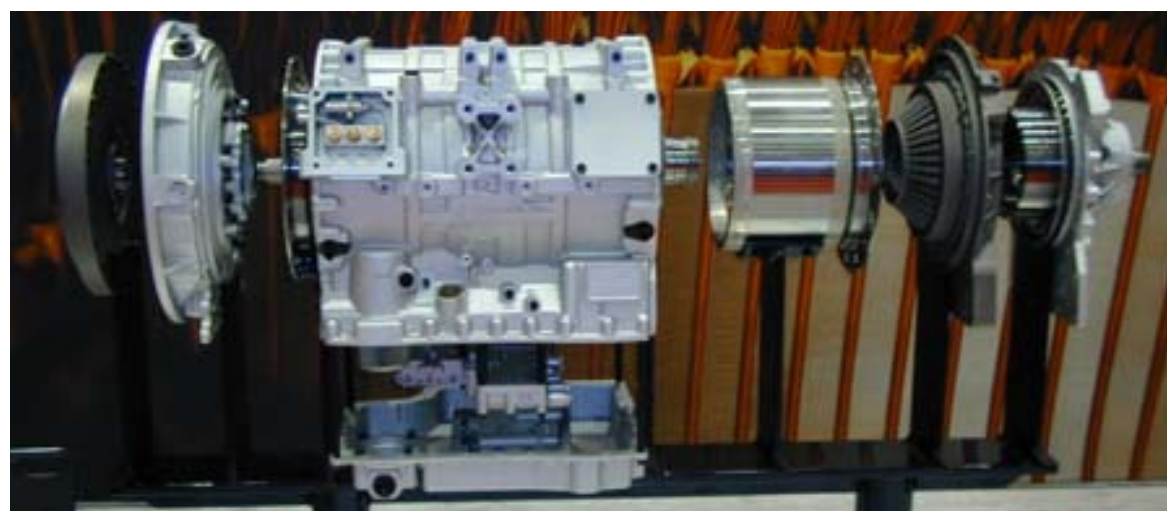

Figure 8. GM Allison Electric Drive Unit

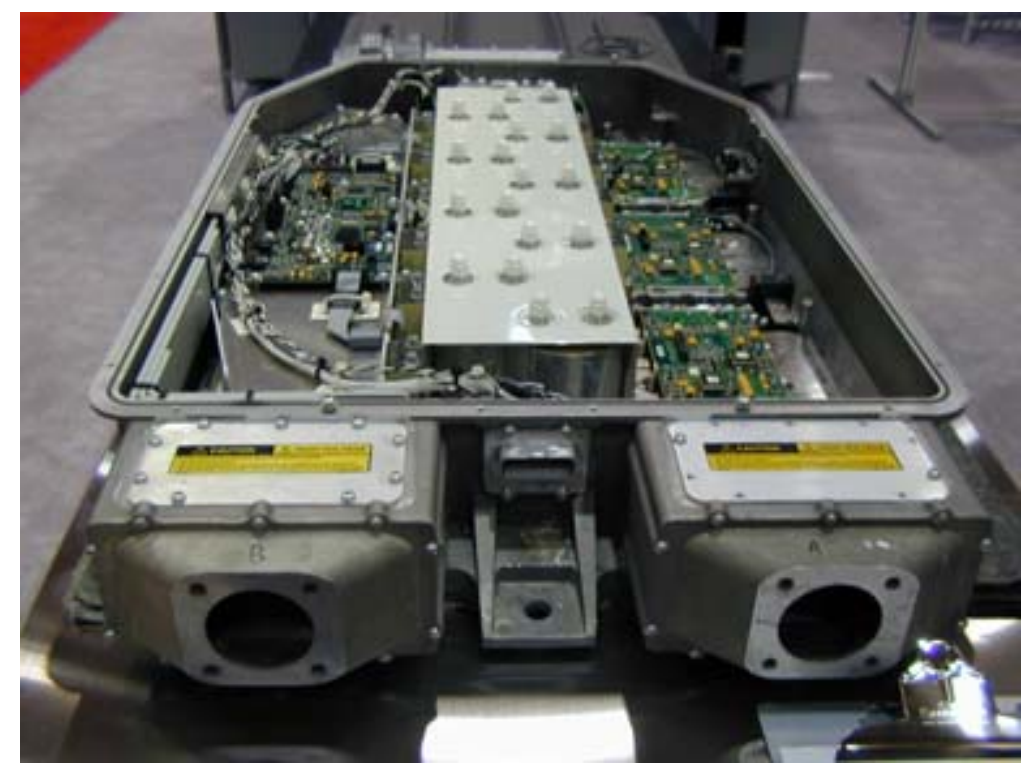

Figure 9. Dual-Power Inverter Module

This need for low tailpipe and noise emissions and adequate battery life resulted in the development of HUSH mode for the hybrid buses. As previously mentioned, HUSH mode operation allows the use of both all-electric operation and a combination of diesel and electric operation. This operation has the following characteristics:

- Before entering the tunnel, the batteries are precharged to maximum state of charge (SOC); the driver pushes a button on the dashboard to start this process.

- The driver initiates HUSH mode by pushing the precharge button one more time before the bus enters the tunnel.

- The tunnel has two types of areas - the big, open station areas and the tunnel tubes between stations.

- The hybrid buses operate in an all-electric mode while in the station areas, but while in the tunnel tube areas, the diesel engine is allowed to operate in reduced-power mode to allow for charging of the batteries (about $110 \mathrm{hp}$ ).

- The timing of the switch between all-electric operation and reduced-power diesel mode is based on vehicle speed once it is in HUSH mode (15 mph or more for reduced-power mode). 
- While in the station area, the bus operates on battery power; however, the engine still rotates to operate auxiliary loads such as the air compressor; when the doors open at a station boarding area, the engine stops until the doors are closed again.

- HUSH mode is automatically de-activated by distance traveled or manually by the driver.

Originally, if a driver break was required, the batteries were precharged by parking the hybrid buses in staging areas at each end of the tunnel until the precharge was complete, which took about 5 minutes. When light rail operation in the tunnel starts, precharging at the staging areas will not be possible. Allison and KC Metro have identified a place at each end of the tunnel where the precharge is now initiated to ensure that the batteries are sufficiently charged before entering the tunnel. In this way, the buses did not need to stop for the precharge, and is now accomplished en route.

The Seattle downtown transit tunnel closed on September 24, 2005, for the addition of light rail. The bus catenary in the tunnel is being removed. According to the plan, the tunnel will be closed for two years, so bus traffic has been moved up onto $3^{\text {rd }}$ Avenue. Routes were changed to accommodate the use of the city street instead of the tunnel. HUSH mode was then deactivated in the hybrid buses in early October 2005 (see campaign item \#6 in the next section). 


\section{Facility Descriptions}

KC Metro operates seven depots for 1,420 standard, articulated, and trolley buses. This evaluation covers diesel and hybrid articulated buses from three of the seven depots. The new diesel articulated study buses operate only from Ryerson Base, and the hybrid articulated study buses operate from South and Atlantic bases. No special facilities or equipment are used for the new diesel and hybrid articulated buses.

South Base is located in Tukwila, 10 miles south of Seattle, and serves mainly intercity routes in the south end and service from southern outlying suburbs into Seattle. The majority of South Base routes are interurban and involve service at relatively high average speeds. Approximately 270 buses operate from South Base. Figure 10 shows the South Base maintenance and office building. Figure 11 shows a hybrid bus leaving South Base for peak evening service.

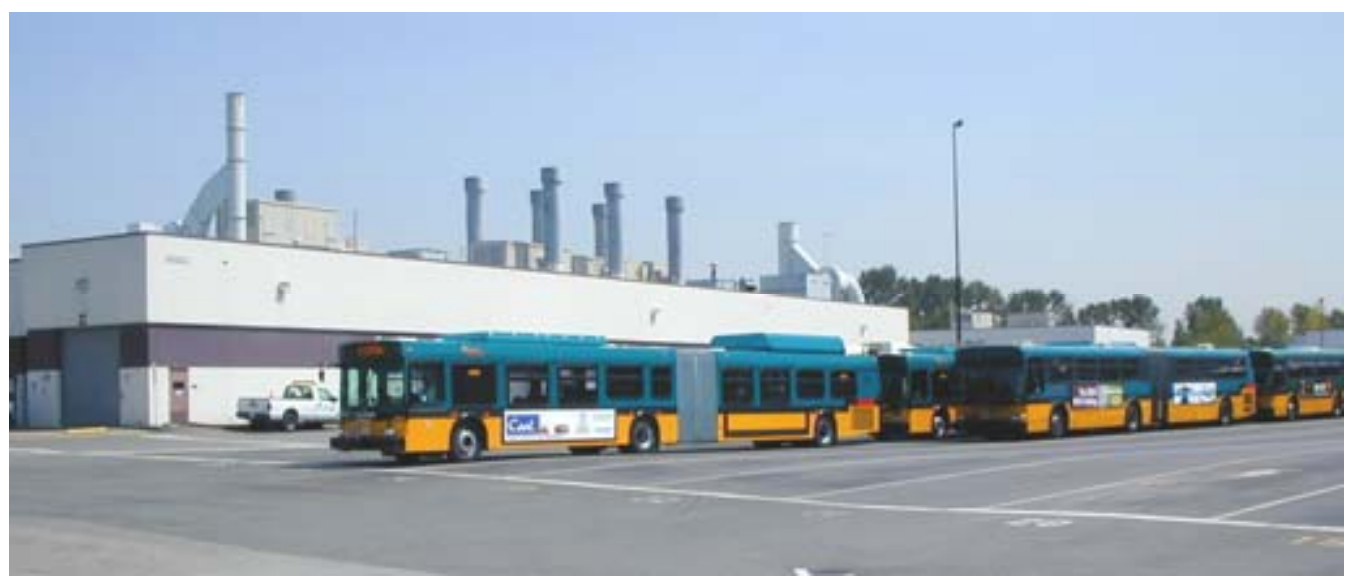

Figure 10. South Base Maintenance and Office Building

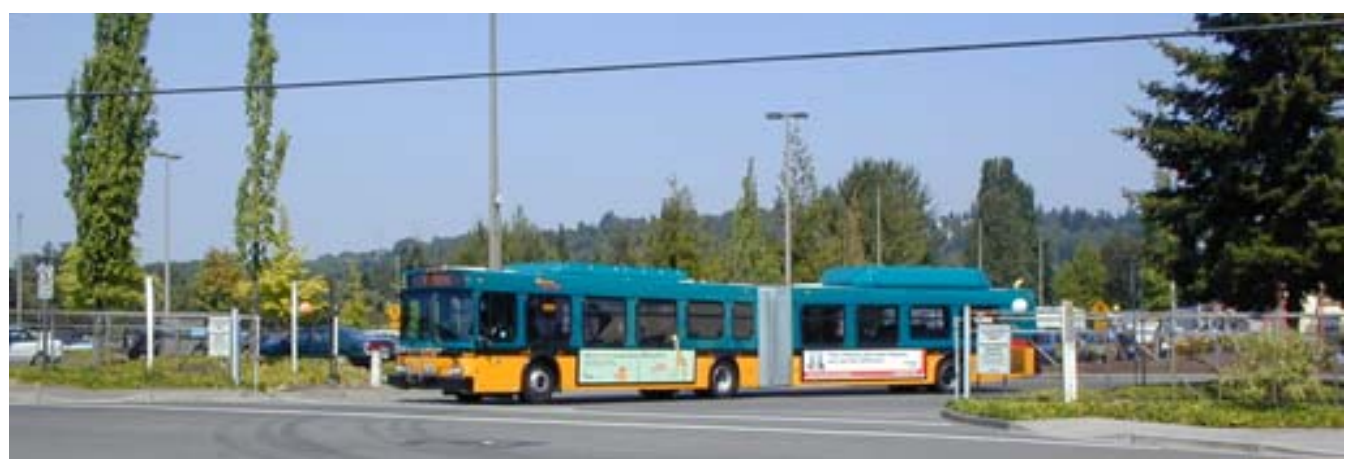

Figure 11. Hybrid Articulated Bus Leaving South Base

The Ryerson and Atlantic bases are both within one mile of the downtown Seattle area and serve mainly downtown-area riders. Some of the routes move outside the Seattle city limits, but most are in and around downtown. The average-speed service for routes from these two bases is similar and lower than the average-speed service for South Base buses. Average speeds and routes will be discussed further in the section on evaluation results in this report. Figures 12 and 13 show Ryerson Base. Figure 14 shows Atlantic Base. 


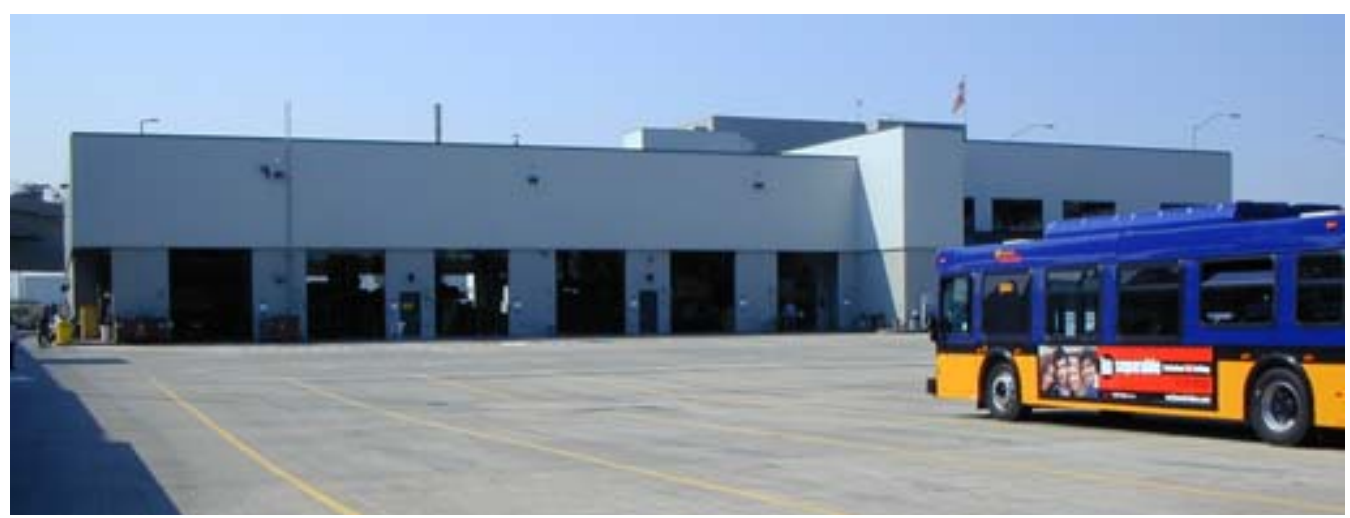

Figure 12. Ryerson Base Maintenance and Office Building

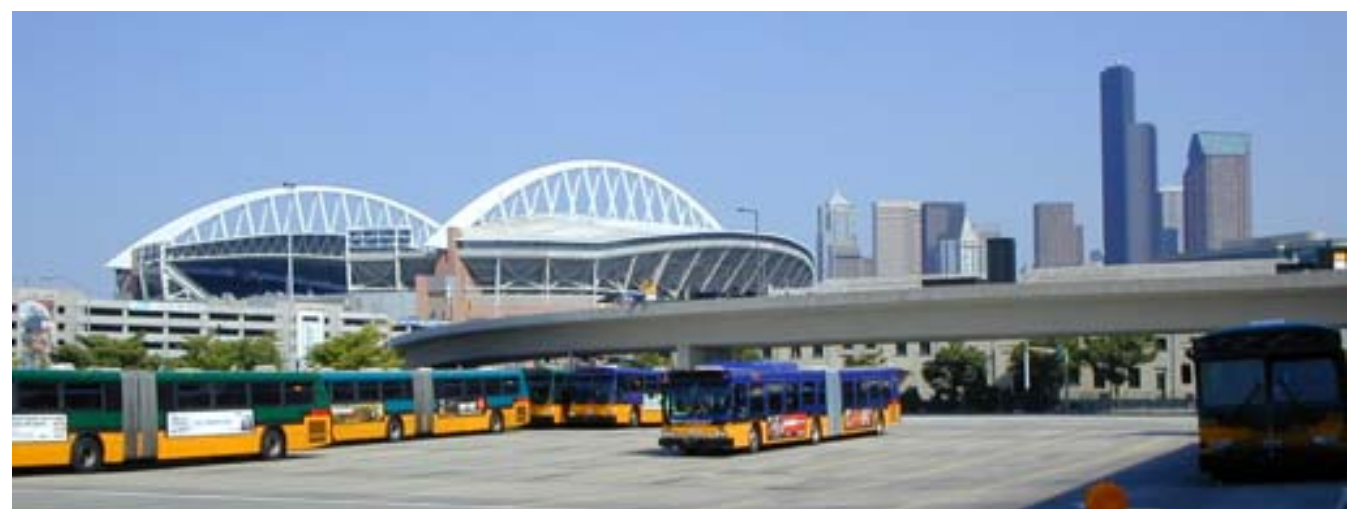

Figure 13. Bus Parking at Ryerson Base, with Part of Seattle Skyline in Background

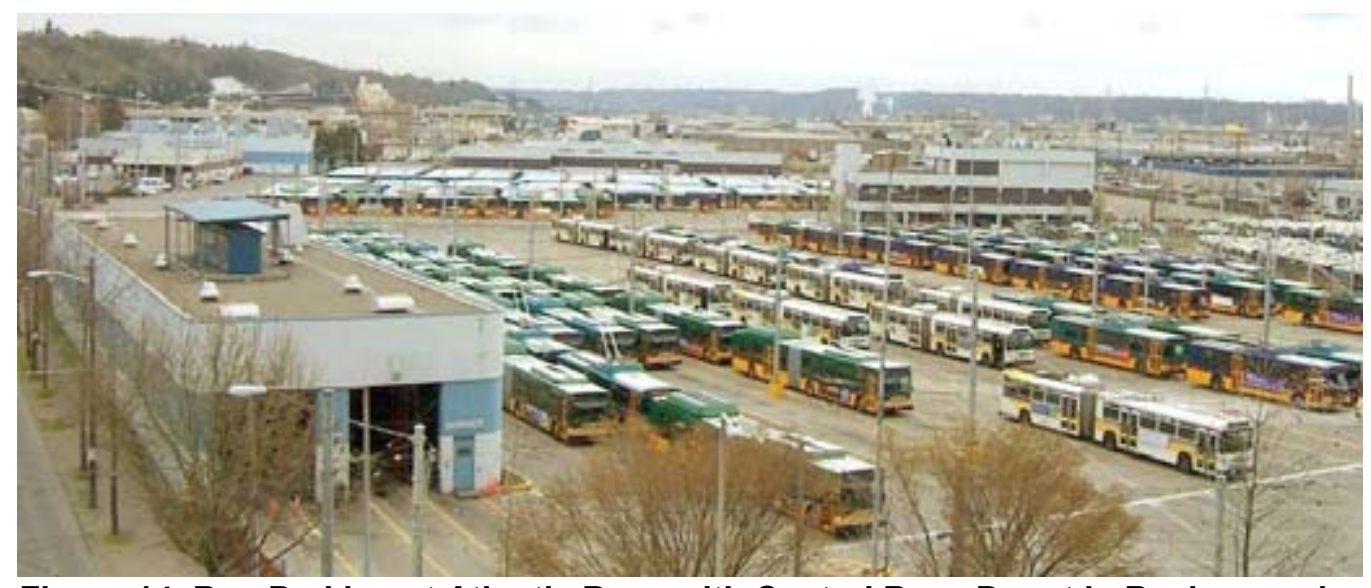

Figure 14. Bus Parking at Atlantic Base with Central Base Depot in Background 


\section{Implementation Experience}

This section discusses overall fleet-level results for mileage accumulations and significant campaign issues associated with the fleet of $213 \mathrm{KC}$ Metro and 22 Sound Transit hybrid buses and $30 \mathrm{KC}$ Metro diesel buses. KC Metro has treated them as standard articulated buses for service. No special treatment was given to the operating bases for pullout requirements.

The hybrid and diesel articulated buses were delivered to KC Metro between May 2004 and early December 2004 and placed in service within a few weeks of delivery. Preparation of a bus only required adding KC Metro equipment, checking the bus's operation for safety, and placing the bus into service. KC Metro's experience overall has been better than expected. The bus operators like the new buses and do not want the old Breda dual-mode buses back. KC Metro reports that vendor support has also been better than expected. Caterpillar and New Flyer each have one technical person available in the Seattle area to help KC Metro place the new buses in service and keep them in service.

As these new diesel and hybrid articulated buses were received and placed in service, the Breda dual-mode buses were removed from the fleet on a one-for-one basis. Figure 15 shows cumulative mileage for all the new hybrid and diesel buses from June 2004 through March 2006. As of March 2006, the 235 hybrid buses had accumulated approximately 13 million miles. The 30 diesel buses had accumulated nearly 1.7 million miles through March 2006.

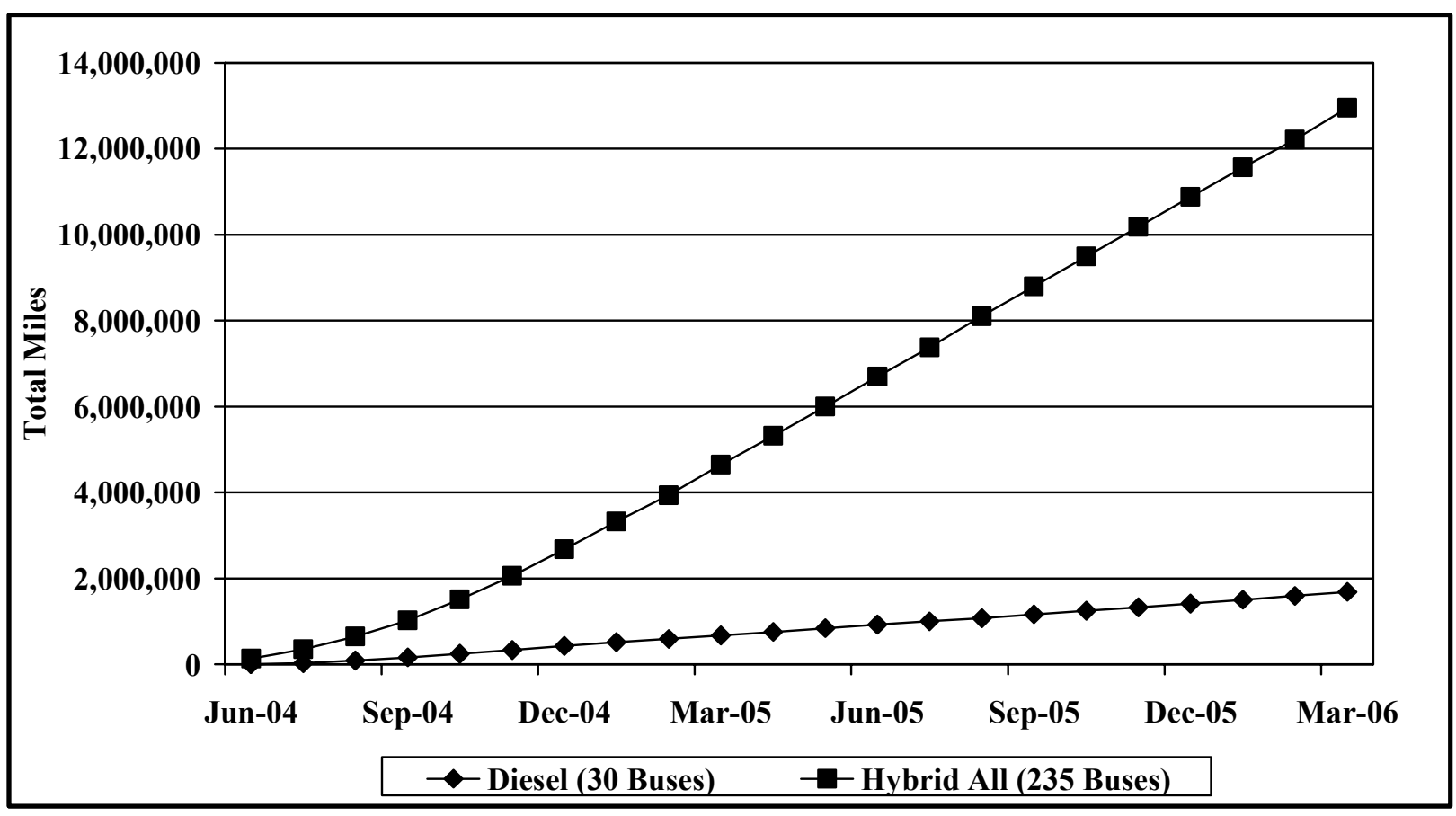

Figure 15. Cumulative Mileage for the Hybrid and Diesel Bus Fleet

Figure 16 displays average monthly mileage per bus for the hybrid and diesel buses. This figure shows that, in general, the buses have been used at a similar rate and have averaged between 
2,500 and 3,000 monthly miles per bus. In the last three months of the data period shown, the diesel buses experienced lower usage as a result of engine problems, which are discussed later.

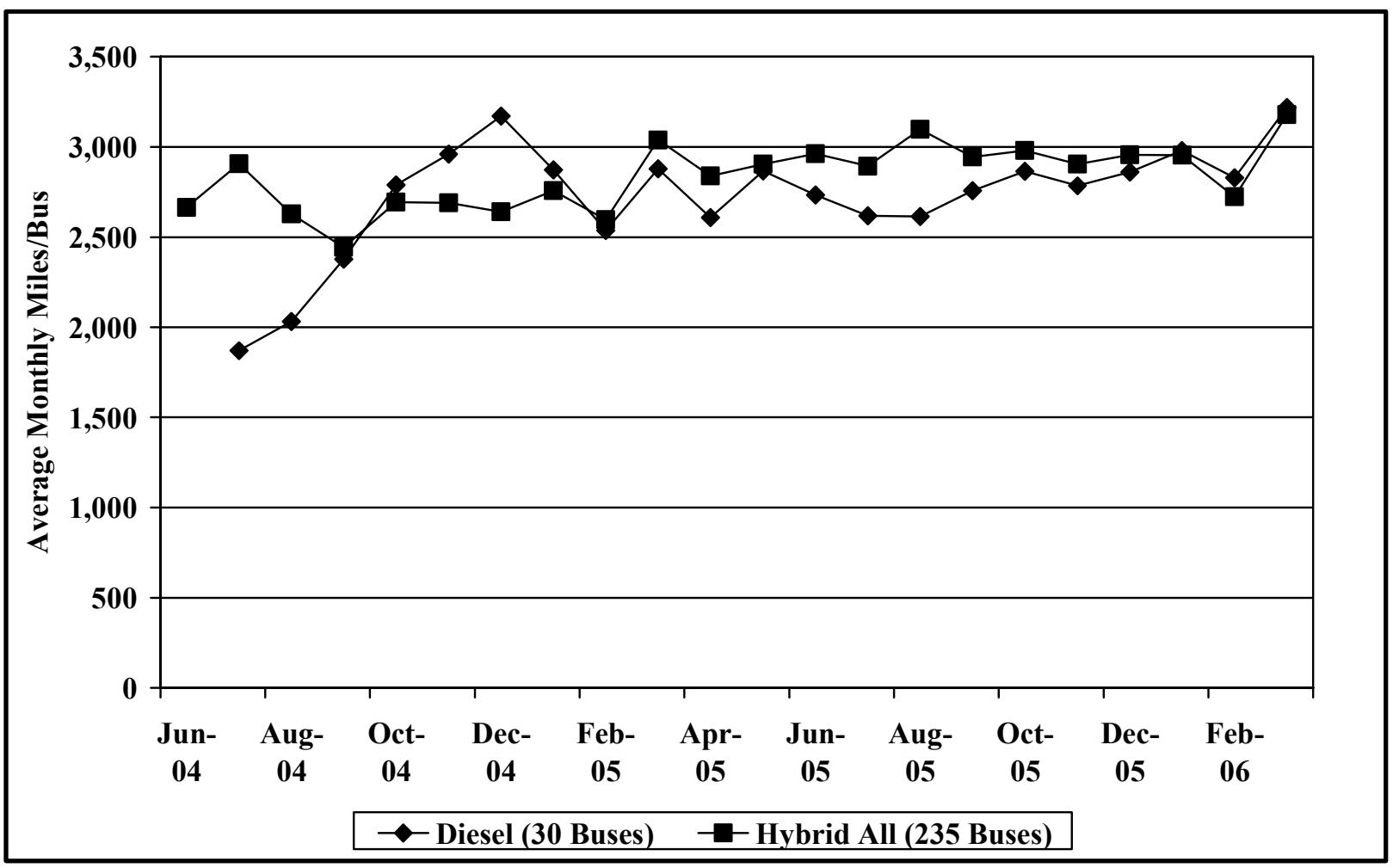

Figure 16. Average Monthly Mileage per Bus for Entire Hybrid and Diesel Bus Fleet

The hybrid and diesel buses have gone into service with only a few significant issues. There have been a few "fleet defects" and "campaigns" of warranty repairs as the manufacturers gained experience with the KC Metro operation and environment and addressed specific design issues involving the integration of the bus systems. A "fleet defect," as defined in the contract between the transit agency and manufacturer, refers to failures of the same type on multiple buses in an order. A "campaign" is a repair, typically covered under warranty, applied to an entire order of buses or significant portion of one. The following list summarizes information about some of the significant campaigns for these buses.

1. Axle planetary snap rings $(8 / 2004)$

2. Allison software upgrade for issues with the inverter and CAT engine software changes $(9 / 2004)$

3. Proheat auxiliary coolant heater software change $(1 / 2005)$

4. Relocation of the DPF and change of the thermal blanket (2/2005)

5. Allison software upgrade for additional CAT engine software changes and HUSH mode hybrid thermal protection $(5 / 2005)$

6. Allison software upgrade for removing HUSH mode and a few software enhancements (10/2005) - removal of HUSH mode was at the request of KCM due to 2 year Transit Tunnel shutdown for remodeling. It will be re-activated again in 2007.

7. Voltage regulator retrofit (11/2005)

8. Replacement of turbocharger, heavier usage than expected, using titanium turbocharger parts $(1 / 2006)$. 
There were also minor campaigns for other bus systems, but those listed were the major changes to the propulsion system. April 1, 2005, was chosen as the "clean point" for the evaluation because the major campaigns were completed and the reliability of the buses was stabilized after January-February 2005. As discussed in the next section, the evaluation period for this report is April 2005 through March 2006.

\section{Evaluation Results (12 Months)}

This evaluation started April 1, 2005 and ran for 12 months through March 31, 2006. The study buses for this evaluation were 10 diesel articulated buses operating from Ryerson Base (Diesel Ryerson Base) and 10 hybrid articulated buses operating from Atlantic Base (Hybrid AB). The 10 hybrid articulated buses operating from South Base (Hybrid SB) are included to describe early implementation experiences and for reference only. One of the hybrid buses at South Base had a turbocharger failure and was incorrectly repaired in March 2005. This caused the engine to be damaged beyond repair, so it was replaced in April 2005. This bus, number 2646, was removed from the evaluation summary results.

As discussed earlier, this evaluation focused on comparing results for diesel buses from Ryerson with those for the hybrid buses from Atlantic. This was done because of the similar duty cycles at Ryerson and Atlantic, but not at South Base. South Base hybrid buses are included in this evaluation report to increase our understanding of the technology, since this was the first operating base to receive hybrid buses at KC Metro. The South Base hybrid buses also allowed us to look into near-term hybrid bus maintenance and reliability issues, since they are the oldest of the hybrid bus fleet studied. Results for the South Base hybrid buses are shown in gray type to distinguish them from other results.

\section{Route Descriptions}

Table 5 shows an average week's work planned for the new articulated buses (hybrid and diesel) at Ryerson, Atlantic, and South Base (note that the results here are slightly different from the Interim Report). These data are based on route assignments as of September 2004 and are valid to the point when the Seattle downtown tunnel was closed in September 2005. As discussed earlier, average speeds were similar at Ryerson and Atlantic: $12.4 \mathrm{mph}$ for Ryerson and 11.6 mph for Atlantic. South Base is significantly different, with an average speed of $19.5 \mathrm{mph}$.

Table 6 shows the same information for Ryerson, Atlantic, and South Base for routes operated after September 2005 when the tunnel closed. 
Table 5. Average Speed for Articulated Buses at Bases with Study Buses (April 2005-September 2005)

\begin{tabular}{|c|c|c|c|c|}
\hline Base & Day of Week & Miles/Day & Hours & Avg. Speed (mph) \\
\hline Ryerson & Weekday & 4,650 & 379.00 & 12.3 \\
\cline { 2 - 5 } & Saturday & 1,006 & 75.05 & 13.4 \\
\cline { 2 - 5 } & Sunday & 1,006 & $\mathbf{7 5 . 1 0}$ & 13.4 \\
\cline { 2 - 5 } & Weekly Total & $\mathbf{2 5 , 2 6 2}$ & $\mathbf{2 , 0 4 5 . 1 0}$ & $\mathbf{1 2 . 4}$ \\
\hline Atlantic & Weekday & 4,856 & 415.84 & 11.7 \\
\cline { 2 - 5 } & Saturday & 2,806 & $\mathbf{2 5 8 . 1 3}$ & 10.9 \\
\cline { 2 - 5 } & Sunday & & & $\mathbf{1 1 . 6}$ \\
\cline { 2 - 5 } & Weekly Total & $\mathbf{2 7 , 0 9 6}$ & $\mathbf{2 , 3 3 7 . 3 3}$ & 19.8 \\
\hline South & Weekday & 11,212 & 567.00 & 18.4 \\
\cline { 2 - 5 } & Saturday & 5,204 & 282.79 & 17.7 \\
\cline { 2 - 5 } & Sunday & 4,180 & 235.93 & 19.5 \\
\cline { 2 - 5 } & Weekly Total & 65,444 & $3,353.32$ & \\
\hline
\end{tabular}

Table 6. Average Speed for Articulated Buses at Bases with Study Buses (September 2005-April 2006)

\begin{tabular}{|c|c|c|c|c|}
\hline Base & Day of Week & Miles/Day & Hours & Avg. Speed (mph) \\
\hline Ryerson & Weekday & 3,895 & 320.00 & 12.2 \\
\cline { 2 - 5 } & Saturday & 1,024 & 77.30 & 13.2 \\
\cline { 2 - 5 } & Sunday & 1,077 & $\mathbf{7 7 . 4 3}$ & 13.9 \\
\cline { 2 - 5 } & Weekly Total & $\mathbf{2 1 , 5 7 6}$ & $\mathbf{1 , 7 5 2 . 8 8}$ & $\mathbf{1 2 . 3}$ \\
\hline Atlantic & Weekday & 6,032 & 575.16 & 10.5 \\
\cline { 2 - 5 } & Saturday & 3,505 & 328.50 & 10.7 \\
\cline { 2 - 5 } & Sunday & 1,837 & 192.57 & 9.6 \\
\cline { 2 - 5 } & Weekly Total & $\mathbf{3 5 , 5 0 2}$ & $\mathbf{3 , 3 9 4 . 8 7}$ & $\mathbf{1 0 . 5}$ \\
\hline South & Weekday & 11,381 & 625.00 & 18.2 \\
\cline { 2 - 5 } & Saturday & 5,042 & 302.22 & 16.7 \\
\cline { 2 - 5 } & Sunday & 4,190 & 236.31 & 17.7 \\
\cline { 2 - 5 } & Weekly Total & 66,137 & $3,662.73$ & 18.1 \\
\hline
\end{tabular}

\section{Bus Usage}

Bus usage is one indicator of the reliability and availability of bus service. The lack of usage may indicate downtime for maintenance or a purposeful reduction of planned work for the buses.

Figure 17 shows cumulative average monthly mileage per bus for the three study groups since they began operating. The general mileage trend for each of the three study groups is slightly higher over time, leveling off toward the end of the data period. The hybrid buses at Atlantic and the diesel buses at Ryerson Base have similar cumulative average monthly mileage-3,096 and 2,948 miles per bus, respectively, during the evaluation period. The hybrid buses at South Base have a usage of just under 4,000 miles per bus, which reflects the higher speed and route mileage duty cycle compared with Ryerson and Atlantic Base operation, which highlights why the data are not comparable.

Table 7 shows average monthly mileage per bus for the study buses during the evaluation period. Usage for the hybrid buses at Atlantic and the diesel buses at Ryerson Base is approximately the same - that for the hybrid buses is 5\% higher. These usage rates support the decision to focus the 
evaluation on the study buses at the Ryerson and Atlantic Base. The hybrid buses at South Base are used in a significantly different manner, averaging 3,957 monthly miles per bus, which is $34 \%$ higher than the mileage for the diesel buses.

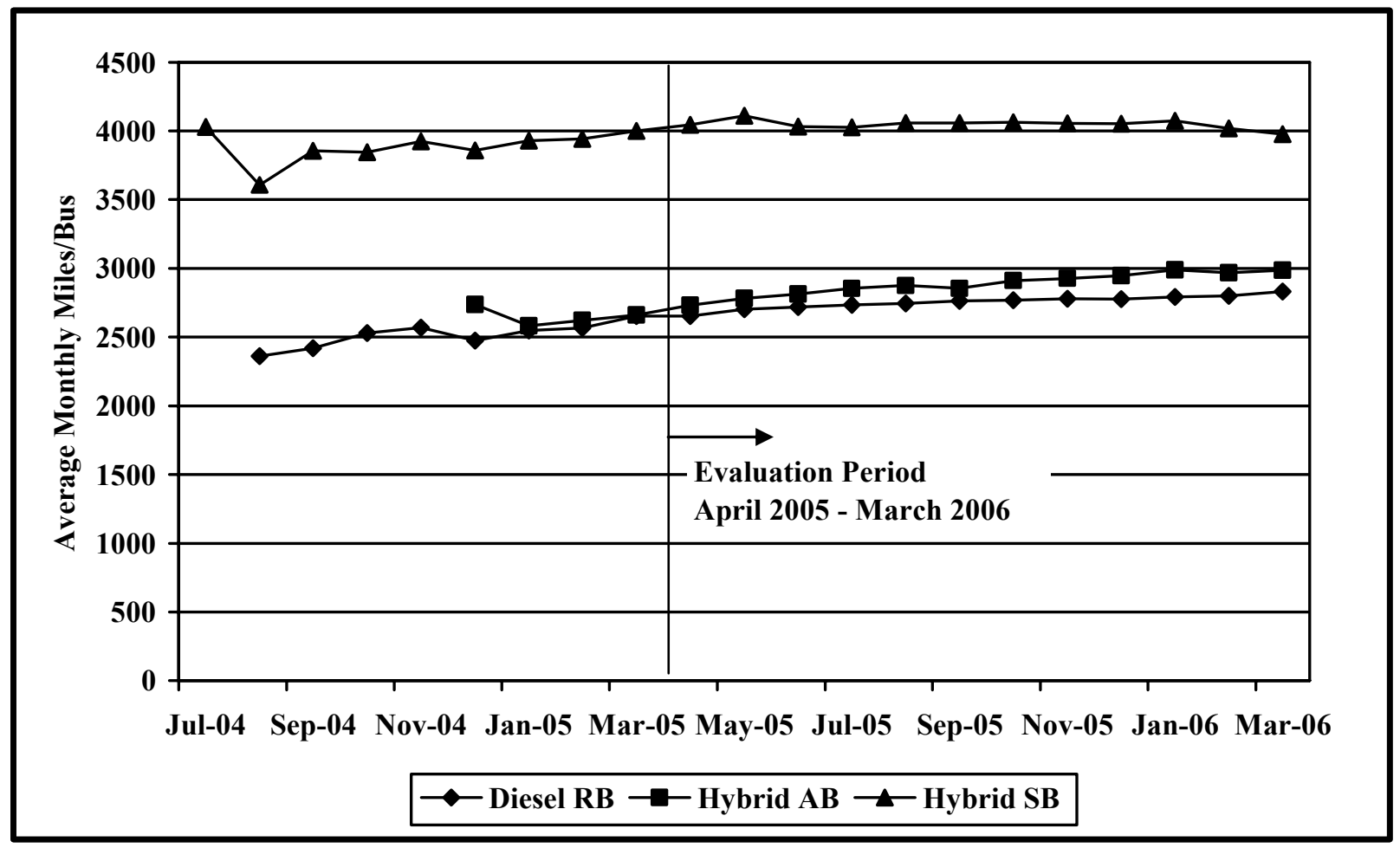

Figure 17. Cumulative Average Monthly Miles per Bus 
Table 7. Monthly Mileage per Study Bus

(12-month evaluation period)

\begin{tabular}{|c|c|c|c|c|c|}
\hline Bus & $\begin{array}{l}\text { Starting } \\
\text { Mileage }\end{array}$ & $\begin{array}{l}\text { Ending } \\
\text { Mileage }\end{array}$ & $\begin{array}{c}\text { Total } \\
\text { Mileage }\end{array}$ & Months & $\begin{array}{l}\text { Monthly } \\
\text { Average }\end{array}$ \\
\hline \multicolumn{6}{|c|}{ Diesel Ryerson Base } \\
\hline 2880 & 22,078 & 54,917 & 32,839 & 12 & 2,737 \\
\hline 2881 & 22,178 & 55,313 & 33,135 & 12 & 2,761 \\
\hline 2882 & 24,569 & 57,025 & 32,456 & 12 & 2,705 \\
\hline 2883 & 21,108 & 57,264 & 36,156 & 12 & 3,013 \\
\hline 2884 & 24,068 & 59,065 & 34,997 & 12 & 2,916 \\
\hline 2885 & 21,764 & 57,595 & 35,831 & 12 & 2,986 \\
\hline 2886 & 22,508 & 58,484 & 35,976 & 12 & 2,998 \\
\hline 2887 & 22,775 & 62,674 & 39,899 & 12 & 3,325 \\
\hline 2888 & 18,259 & 55,395 & 37,136 & 12 & 3,095 \\
\hline \multirow{2}{*}{2889} & 21,932 & 57,292 & 35,360 & 12 & 2,947 \\
\hline & & & 353,785 & 120 & 2,948 \\
\hline \multicolumn{6}{|c|}{ Hybrid AB } \\
\hline 2780 & 6,791 & 45,560 & 38,769 & 12 & 3,231 \\
\hline 2781 & 7,439 & 41,597 & 34,158 & 12 & 2,847 \\
\hline 2782 & 6,243 & 38,296 & 32,053 & 12 & 2,671 \\
\hline 2783 & 7,450 & 44,525 & 37,075 & 12 & 3,090 \\
\hline 2784 & 7,626 & 47,703 & 40,077 & 12 & 3,340 \\
\hline 2785 & 4,134 & 42,455 & 38,321 & 12 & 3,193 \\
\hline 2786 & 6,615 & 46,563 & 39,948 & 12 & 3,329 \\
\hline 2787 & 6,224 & 39,126 & 32,902 & 12 & 2,742 \\
\hline 2788 & 7,111 & 45,220 & 38,109 & 12 & 3,176 \\
\hline \multirow[t]{2}{*}{2789} & 5,938 & 46,074 & 40,136 & 12 & 3,345 \\
\hline & & & 371,548 & 120 & 3,096 \\
\hline \multicolumn{6}{|c|}{ Hybrid SB } \\
\hline 2640 & 37,180 & 83,119 & 45,939 & 12 & 3,828 \\
\hline 2641 & 41,580 & 91,093 & 49,513 & 12 & 4,126 \\
\hline 2642 & 34,009 & 79,845 & 45,845 & 12 & 3,820 \\
\hline 2643 & 35,419 & 80,193 & 44,774 & 12 & 3,731 \\
\hline 2644 & 31,062 & 77,696 & 46,634 & 12 & 3,886 \\
\hline 2645 & 36,879 & 82,253 & 45,374 & 12 & 3,781 \\
\hline 2647 & 35,343 & 86,997 & 51,654 & 12 & 4,305 \\
\hline 2648 & 36,025 & 85,330 & 49,305 & 12 & 4,109 \\
\hline \multirow[t]{2}{*}{2649} & 36,548 & 84,841 & 48,293 & 12 & 4,024 \\
\hline & & & 427,331 & 108 & 3,957 \\
\hline
\end{tabular}

\section{Fuel Economy and Cost}

KC Metro buses use ULSD fuel, which has a sulfur content less than $15 \mathrm{ppm}$. Instead of ULSD, Ryerson Base diesel buses use a 5\% biodiesel blended with ULSD (B5), which has virtually the same energy content ( $<1 \%$ difference). Table 8 summarizes fuel economy results for the 30 study buses. The hybrid buses from Atlantic Base had a 27\% higher fuel economy on average compared with that of diesel buses at Ryerson Base (26\% higher for the first six months of the evaluation period, as stated in the interim report). This comparison is the most applicable because of the similar usage and duty cycles, as discussed earlier. The South Base hybrid buses have operated in a higher average speed duty cycle and have a fuel economy that is $50 \%$ higher 
on average than that of the diesel buses at Ryerson Base and 18\% higher than that of the other hybrid buses at Atlantic Base.

Figure 18 shows average fuel economies for the Ryerson and Atlantic study groups since the beginning of their operation at KC Metro (the evaluation period is indicated). The diesel buses at Ryerson Base had an average fuel economy that started at around $2.2 \mathrm{mpg}$ and increased to around $2.5 \mathrm{mpg}$ from August-October 2004. This increase was accomplished through a software change in the CAT engine. The diesel buses have operated at around $2.5 \mathrm{mpg}$ since the first three months of operation. All of the CAT engines (diesel and hybrid) received this software update.

Table 8. Fuel Use and Economy (12-month evaluation period)

\begin{tabular}{|c|c|c|c|}
\hline Bus & $\begin{array}{c}\text { Mileage } \\
\text { (Fuel Base) }\end{array}$ & $\begin{array}{l}\text { Gallons } \\
\text { Consumed }\end{array}$ & $\begin{array}{c}\text { Miles per } \\
\text { Gallon }\end{array}$ \\
\hline \multicolumn{4}{|c|}{ Diesel Ryerson Base } \\
\hline 2880 & 32,773 & 12,836 & 2.55 \\
\hline 2881 & 32,118 & 12,921 & 2.49 \\
\hline 2882 & 31,999 & 12,785 & 2.50 \\
\hline 2883 & 36,079 & 14,564 & 2.48 \\
\hline 2884 & 34,997 & 14,389 & 2.43 \\
\hline 2885 & 35,514 & 13,637 & 2.60 \\
\hline 2886 & 35,620 & 14,549 & 2.45 \\
\hline 2887 & 39,408 & 15,818 & 2.49 \\
\hline 2888 & 36,699 & 14,258 & 2.57 \\
\hline \multirow[t]{2}{*}{2889} & 35,361 & 14,240 & 2.48 \\
\hline & 350,567 & 139,996 & 2.50 \\
\hline \multicolumn{4}{|c|}{ Hybrid AB } \\
\hline 2780 & 37,465 & 11,876 & 3.15 \\
\hline 2781 & 33,521 & 10,438 & 3.21 \\
\hline 2782 & 31,409 & 10,268 & 3.06 \\
\hline 2783 & 36,629 & 11,653 & 3.14 \\
\hline 2784 & 39,768 & 12,069 & 3.30 \\
\hline 2785 & 37,512 & 11,856 & 3.16 \\
\hline 2786 & 37,962 & 11,737 & 3.23 \\
\hline 2787 & 31,341 & 10,107 & 3.10 \\
\hline 2788 & 36,699 & 11,527 & 3.18 \\
\hline \multirow[t]{2}{*}{2789} & 39,753 & 12,523 & 3.17 \\
\hline & 362,049 & 114,054 & 3.17 \\
\hline \multicolumn{4}{|c|}{ Hybrid SB } \\
\hline 2640 & 41,908 & 11,343 & 3.69 \\
\hline 2641 & 41,005 & 10,921 & 3.75 \\
\hline 2642 & 41,708 & 11,065 & 3.77 \\
\hline 2643 & 39,400 & 10,562 & 3.73 \\
\hline 2644 & 43,036 & 11,627 & 3.70 \\
\hline 2645 & 39,319 & 10,850 & 3.62 \\
\hline 2647 & 47,374 & 12,652 & 3.74 \\
\hline 2648 & 43,217 & 11,148 & 3.88 \\
\hline \multirow[t]{2}{*}{2649} & 42,361 & 11,007 & 3.85 \\
\hline & 379,328 & 101,174 & 3.75 \\
\hline
\end{tabular}




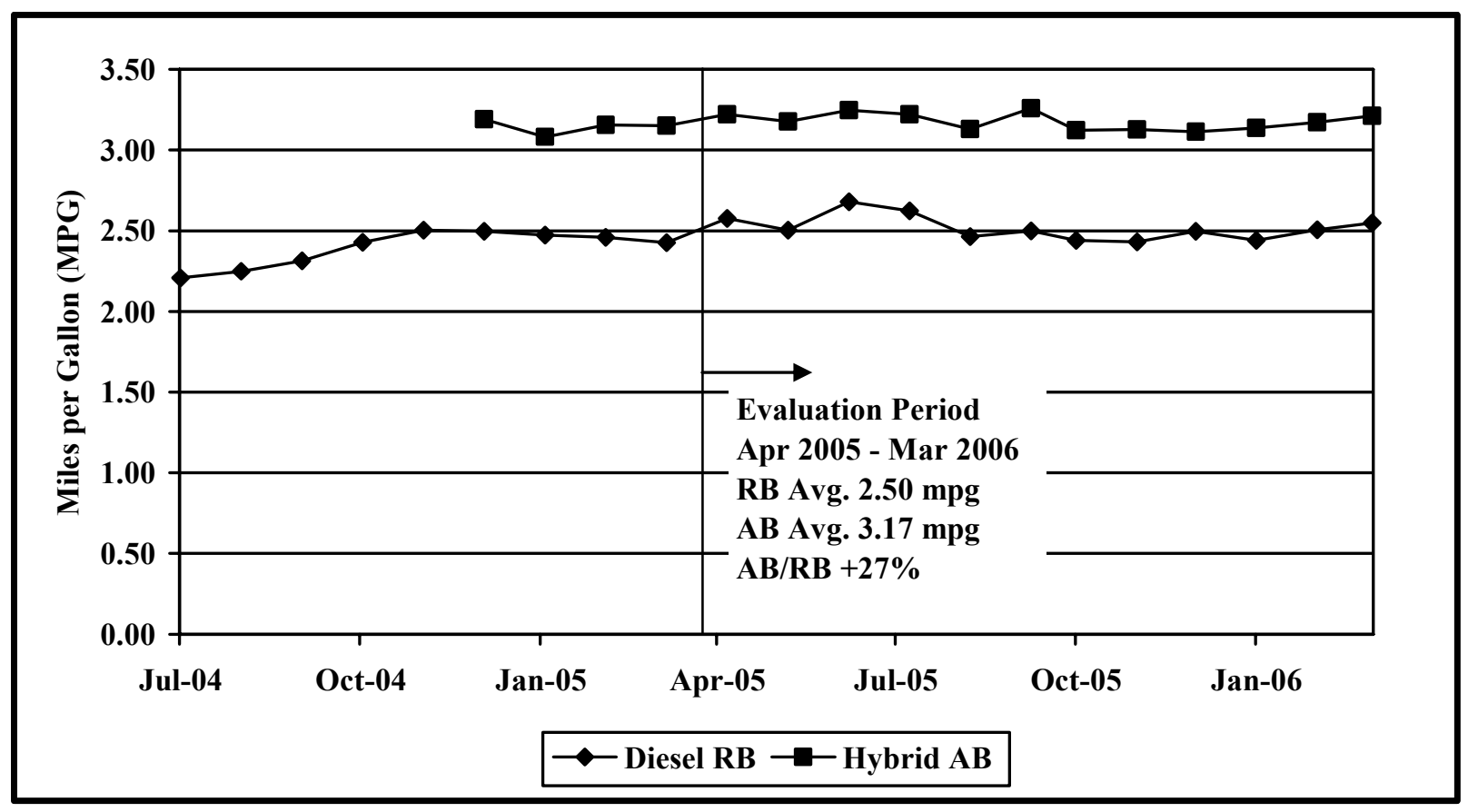

Figure 18. Average Fuel Economy (mpg)

For a controlled, detailed, direct fuel economy comparison of similar routes, KC Metro recommended Route 120 operated from Ryerson Base and Route 106 operated from Atlantic Base (which initially operated in the downtown tunnel). For the study buses at these two operating bases, route and fuel consumption data were used to compare fuel economies calculated from operation on the two bus routes. During the first 6 months of the evaluation period (April-September 2005), the hybrid buses operated in the Seattle downtown bus tunnel using HUSH mode showed a 21\% higher fuel economy. During the second 6 months of the evaluation period (October 2005 to March 2006), the hybrid buses were not operated in the tunnel (HUSH mode was not used), and the hybrid buses showed a $22 \%$ higher fuel economy than the diesel buses. Table 9 shows the results of this comparison for the evaluation period.

Table 9. Fuel Economy Comparison for Route 120 and Route 106 (Six-month evaluation period)

\begin{tabular}{|l|c|c|c|c|}
\hline \multicolumn{1}{|c|}{ Timeframe } & Buses & Route & $\begin{array}{c}\text { Average } \\
\text { Speed }\end{array}$ & Fuel Economy \\
\hline $4 / 05-9 / 05$ & $\begin{array}{c}\text { Diesel } \\
\text { Ryerson } \\
\text { Base }\end{array}$ & 120 & 12.9 & 2.54 \\
\hline (In Tunnel) & Hybrid AB & 106 & 12.3 & 3.08 \\
\hline \multicolumn{4}{|c|}{ Percent Difference (Hybrid/Diesel) } & $\mathbf{2 1 \%}$ \\
\hline $10 / 05-3 / 06$ & $\begin{array}{c}\text { Diesel } \\
\text { Ryerson } \\
\text { Base }\end{array}$ & 120 & 12.9 & 2.53 \\
\hline (Out of Tunnel) & Hybrid AB & 106 & 12.1 & 3.09 \\
\hline \multicolumn{7}{|c|}{ Percent Difference (Hybrid/Diesel) } & $\mathbf{2 2 \%}$ \\
\hline
\end{tabular}

Actual fuel costs during the evaluation period were \$1.98 per gallon for the ULSD at KC Metro. The diesel buses at Ryerson Base used a biodiesel blend of 5\% by volume biodiesel in diesel fuel 
(B5). The use of the B5 blend at Ryerson Base was not a technical requirement for the diesel buses but it was used $100 \%$ of the time at that depot. This use of biodiesel caused the fuel cost per gallon at Ryerson Base to be $\$ 0.03$ to $\$ 0.05$ per gallon higher than for just diesel fuel use; however, this additional cost has not been used. Costs per mile for each of the three study bus groups with diesel fuel at $\$ 1.98$ per gallon average are as follows:

- $\quad$ Diesel $\mathrm{RB}=\$ 0.79$ per mile

- Hybrid $\mathrm{AB}=\$ 0.62$ per mile

- Hybrid $\mathrm{SB}=\$ 0.53$ per mile.

This translates to a cost per mile $22 \%$ lower for the Atlantic Base hybrid buses when compared with the Ryerson Base diesel buses.

\section{Maintenance Cost Analysis}

The maintenance cost analysis in this section focuses on the evaluation period (April 2005March 2006). However, some of the analyses compare results from the time prior to the evaluation period, typically back to the start of operation for the study buses. The data period is clearly indicated for each figure in this section. Warranty costs are not included in this section but are analyzed separately later. All work orders since the beginning of the operation of the study buses were collected and analyzed for this evaluation. The labor rate for maintenance was kept at a constant $\$ 50$ per hour, and this does not reflect an average rate at KC Metro. This section first discusses total maintenance costs and then maintenance costs broken down by bus system.

Total Maintenance Costs. Total maintenance costs include the actual cost of parts and hourly labor costs at $\$ 50$ per hour and do not include warranty costs. Cost per mile is calculated as follows: Cost per mile $=[($ labor hours $* 50)+$ parts cost $] /$ mileage.

Table 10 shows total maintenance costs during the evaluation period for the diesel and hybrid study buses at the two depots. The two study groups of buses had similar total maintenance cost for the evaluation period (4\% lower for the hybrid buses at Atlantic Base compared to the diesel buses at Ryerson Base). South Base depot results are shown in Table 10 for reference only.

The Ryerson diesel study group had one bus with higher maintenance costs (bus 2889), which were caused by significant heating, ventilation, and air-conditioning (HVAC) repairs in January 2006 along with soot filter repairs. The Atlantic hybrid study group also had one bus with higher maintenance costs (bus 2781), which were caused by significant repairs to the steering system in November 2005, repairs for vandalism in February 2006, minor accident repairs in March 2006, and significant repairs for the differential in March 2006. 
Table 10. Total Maintenance Costs (12-month evaluation period)

\begin{tabular}{|c|c|c|c|c|}
\hline Bus & Mileage & $\begin{array}{c}\text { Parts } \\
\text { Cost (\$) }\end{array}$ & $\begin{array}{l}\text { Labor } \\
\text { Hours }\end{array}$ & $\begin{array}{l}\text { Cost per } \\
\text { Mile (\$) }\end{array}$ \\
\hline \multicolumn{5}{|c|}{ Diesel Ryerson Base } \\
\hline 2880 & 32,839 & $3,382.66$ & 257.7 & 0.50 \\
\hline 2881 & 33,135 & $2,368.47$ & 270.5 & 0.48 \\
\hline 2882 & 32,456 & $3,517.79$ & 214.0 & 0.44 \\
\hline 2883 & 36,156 & $3,467.79$ & 241.0 & 0.43 \\
\hline 2884 & 34,997 & $3,448.13$ & 255.4 & 0.46 \\
\hline 2885 & 35,831 & $3,323.60$ & 260.1 & 0.46 \\
\hline 2886 & 35,976 & $2,836.40$ & 239.2 & 0.41 \\
\hline 2887 & 39,899 & $3,292.13$ & 241.2 & 0.39 \\
\hline 2888 & 37,136 & $2,841.93$ & 304.4 & 0.49 \\
\hline 2889 & 35,360 & $4,076.15$ & 332.1 & 0.59 \\
\hline Avg. & 35,379 & $3,255.51$ & 261.5 & 0.46 \\
\hline \multicolumn{5}{|c|}{ Hybrid Atlantic Base } \\
\hline 2780 & 38,769 & $4,279.80$ & 283.0 & 0.48 \\
\hline 2781 & 34,158 & $5,419.23$ & 322.3 & 0.63 \\
\hline 2782 & 32,053 & $1,969.08$ & 274.1 & 0.49 \\
\hline 2783 & 37,075 & $2,834.53$ & 229.1 & 0.39 \\
\hline 2784 & 40,077 & $4,535.76$ & 252.7 & 0.43 \\
\hline 2785 & 38,321 & $2,654.11$ & 251.2 & 0.40 \\
\hline 2786 & 39,948 & $3,548.54$ & 231.4 & 0.38 \\
\hline 2787 & 32,902 & $4,442.49$ & 239.2 & 0.50 \\
\hline 2788 & 38,109 & $5,676.97$ & 238.5 & 0.46 \\
\hline 2789 & 40,136 & $3,959.38$ & 193.0 & 0.34 \\
\hline Avg. & 37,155 & $3,931.99$ & 251.4 & 0.44 \\
\hline \multicolumn{5}{|c|}{ Hybrid South Base } \\
\hline 2640 & 45,939 & $2,585.81$ & 392.1 & 0.48 \\
\hline 2641 & 49,513 & $4,757.51$ & 366.1 & 0.47 \\
\hline 2642 & 45,845 & $2,453.56$ & 267.6 & 0.35 \\
\hline 2643 & 44,774 & $2,056.86$ & 266.8 & 0.34 \\
\hline 2644 & 46,634 & $3,467.61$ & 337.9 & 0.44 \\
\hline 2645 & 45,374 & $2,425.35$ & 348.9 & 0.44 \\
\hline 2647 & 51,654 & $3,716.83$ & 362.3 & 0.42 \\
\hline 2648 & 49,305 & $4,105.09$ & 333.7 & 0.42 \\
\hline 2649 & 48,293 & $2,612.92$ & 271.6 & 0.34 \\
\hline Avg. & 47,481 & $3,131.28$ & 327.4 & 0.41 \\
\hline
\end{tabular}

Figure 19 shows cumulative total maintenance costs for the Ryerson and Atlantic study bus groups from the start of operation through March 2006. In general, the Ryerson Base diesel buses and Atlantic Base hybrid buses had similar total maintenance costs for most of the period shown, and the costs trended slightly higher at the end of the evaluation period. 


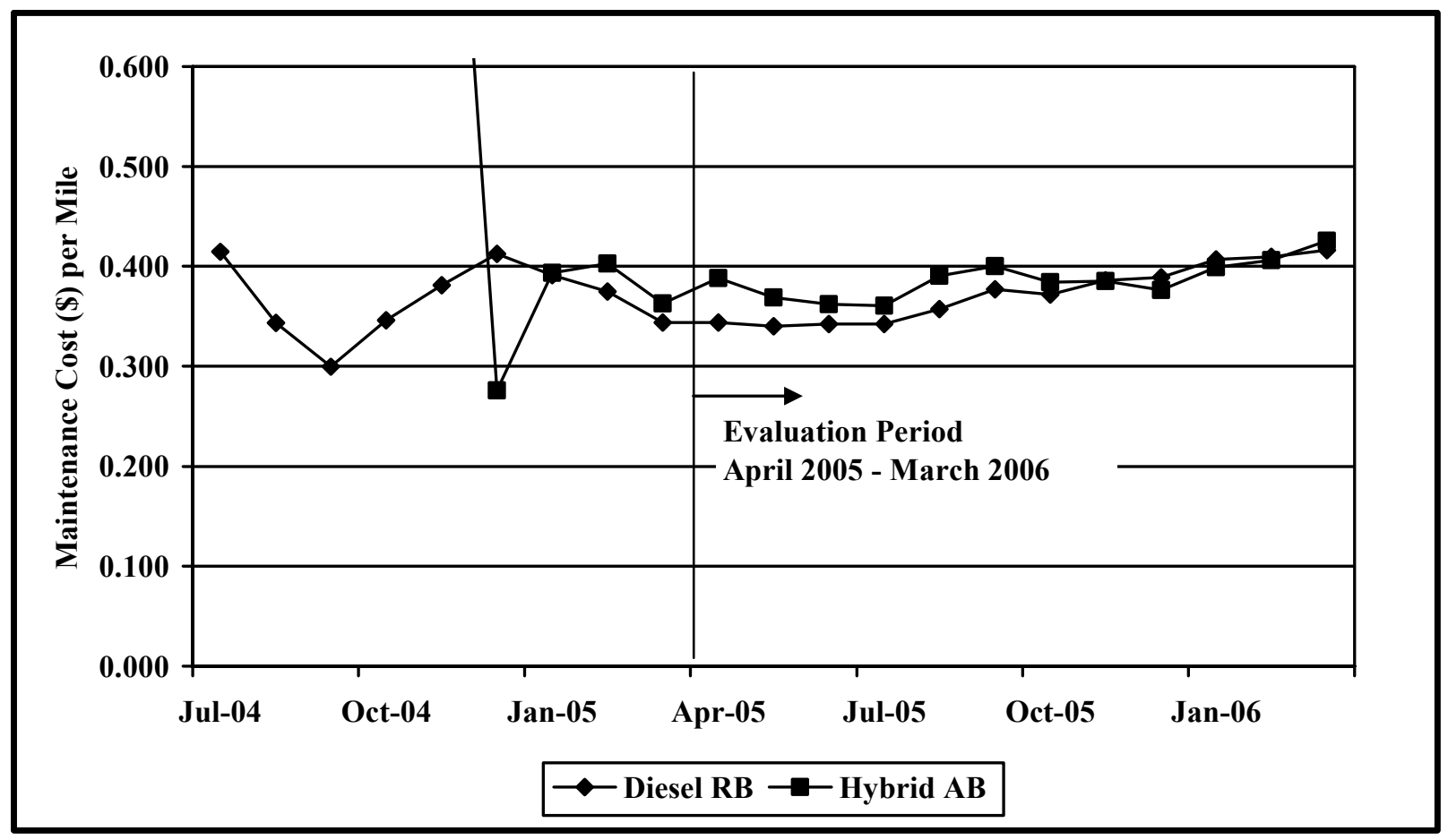

Figure 19. Cumulative Maintenance Cost per Mile (All data)

Maintenance Cost Breakdown by System. Table 11 shows maintenance costs by vehicle system and bus study group. The vehicle systems shown in the table include the following:

- Air system, general

- Axles, wheels, and drive shaft

- Brakes - Excludes regenerative braking for the hybrids, which is included in propulsionrelated systems

- Cab, body, and accessories - Includes body repairs following accidents, glass, and paint; $\mathrm{cab}$ and sheet metal repairs on seats and doors; and accessory repairs such as hubodometers and radios

- Frame, steering, and suspension-Includes steering and suspension repairs

- HVAC

- Lighting

- Preventive maintenance inspections (PMI) — Labor for inspections during preventive maintenance

- Propulsion-related systems - Repairs for exhaust, fuel, and engine; electric motors, traction batteries, and propulsion control; nonlighting electrical (charging, cranking, and ignition); air intake, cooling, hydraulics, and transmission

- Tires.

The four highest-cost repair categories for all three bus study groups were cab, body, and accessories; propulsion-related; HVAC; and PMI. There were no major brake repairs in the three study groups. 
Table 11. Breakdown of Vehicle System Maintenance Cost per Mile (12-month evaluation period)

\begin{tabular}{|c|c|c|c|c|c|c|}
\hline \multirow[b]{2}{*}{$\begin{array}{c}\text { System } \\
\text { (in order of cost) }\end{array}$} & \multicolumn{2}{|c|}{ Diesel Ryerson } & \multicolumn{2}{|c|}{ Hybrid Atlantic } & \multicolumn{2}{|c|}{ Hybrid South } \\
\hline & $\begin{array}{l}\text { Cost per } \\
\text { Mile (\$) }\end{array}$ & $\begin{array}{l}\text { Percent of } \\
\text { Total (\%) }\end{array}$ & $\begin{array}{l}\text { Cost per } \\
\text { Mile (\$) }\end{array}$ & $\begin{array}{l}\text { Percent of } \\
\text { Total (\%) }\end{array}$ & $\begin{array}{l}\text { Cost per } \\
\text { Mile (\$) }\end{array}$ & $\begin{array}{c}\text { Percent } \\
\text { of Total } \\
(\%)\end{array}$ \\
\hline $\begin{array}{l}\text { Cab, Body, and } \\
\text { Accessories }\end{array}$ & 0.16 & 35 & 0.19 & 43 & 0.14 & 34 \\
\hline Propulsion-Related & 0.12 & 26 & 0.13 & 30 & 0.13 & 32 \\
\hline HVAC & 0.07 & 16 & 0.04 & 10 & 0.04 & 10 \\
\hline PMI & 0.05 & 11 & 0.05 & 11 & 0.04 & 10 \\
\hline $\begin{array}{l}\text { Frame, Steering, and } \\
\text { Suspension }\end{array}$ & 0.01 & 2 & 0.01 & 2 & 0.01 & 2 \\
\hline Lighting & 0.01 & 2 & 0.00 & 0 & 0.00 & 0 \\
\hline Air, General & 0.01 & 2 & 0.00 & 0 & 0.01 & 2 \\
\hline $\begin{array}{l}\text { Axles, Wheels, and } \\
\text { Drive Shaft }\end{array}$ & 0.02 & 4 & 0.01 & 2 & 0.01 & 2 \\
\hline Brakes & 0.00 & 0 & 0.01 & 2 & 0.00 & 0 \\
\hline Tires & 0.00 & 0 & 0.00 & 0 & 0.00 & 0 \\
\hline Articulation Joint & 0.01 & 2 & 0.00 & 0 & 0.03 & 8 \\
\hline Total & 0.46 & 100 & 0.44 & 100 & 0.41 & 100 \\
\hline
\end{tabular}

Cab, Body, and Accessories Maintenance Costs. The maintenance costs associated with these systems are shown by bus study group. The following describes each subsystem in this category.

- Body exterior - Includes all body panels and compartment doors, as well as reflectors

- Destination signs

- Cleaning-All cleaning activities inside and outside the bus

- Door and interlock - Includes anything that has to do with the doors and interlock system except the brakes

- Farebox

- Fire extinguisher

- General interior and seats

- Horn

- Mirrors - All inside and outside mirrors

- Radio

- Supplies and expendable items - Includes painting supplies, tools, wipes, eyeglasses, and coveralls assigned to a bus

- Wheelchair ramp - Includes all repairs for the wheelchair ramp system except hydraulics

- Windshield wipers - Includes the wipers, motors, and washer systems.

The maintenance costs for the hybrid buses at Atlantic Base in this category were slightly higher than those for the diesel buses, and the costs for the hybrid buses at South Base were slightly lower than those of the diesel buses. The highest-cost subsystems in this category were cleaning, farebox, body-exterior, and general interior and seats.

Propulsion-Related Maintenance Costs. The propulsion-related vehicle systems include the exhaust, fuel, engine, electric propulsion, air intake, cooling, nonlighting electrical (charging, cranking, and ignition), transmission, and hydraulic systems. The cooling system also includes 
an auxiliary coolant heater (manufactured by Proheat) to ensure that the engine coolant warms up quickly at startup. At other times, this auxiliary coolant heater is used in conjunction with the HVAC system of the bus.

Table 12 shows the total propulsion-related maintenance costs and lists each of the system maintenance costs that make up propulsion-related maintenance for the three study groups of buses. All comparison calculations are for the hybrid compared with the diesel buses from Ryerson Base.

The propulsion-related maintenance cost per mile for the Atlantic Base hybrid buses are nearly the same (\$0.01 per mile higher or 5\% higher) as that for the Ryerson Base diesel buses. The cost per mile for the South Base hybrid buses are essentially the same as that of the diesel buses. The following list is a breakdown of propulsion-related maintenance costs during the evaluation period and focused on the study buses at Ryerson and Atlantic Bases (as shown in Table 12).

- Air intake system maintenance-These costs were low and similar for the two study groups.

- Cooling system maintenance-These costs were lower for the hybrid bus study group than for the diesel buses. The diesel buses had higher labor hours spent on repairs for this system (mostly for the auxiliary coolant heater).

- Electric propulsion maintenance (reference only) - When comparing the two depots with hybrids (which have different duty cycles), costs were lower in this category for the Atlantic Base hybrid buses, and those of the South Base hybrid buses were higher at $\$ 0.04$ per mile. The higher cost for the South Base hybrid buses was caused by a high number of labor hours spent to troubleshoot problems with the propulsion system (perhaps because South Base was the first to receive hybrids). For two of the hybrid buses in the South Base study group, labor hours were significant and included investigating a problem with the cooling lines for the DPIM. Four DPIMs were replaced in the South Base hybrid buses, and two were replaced in the Atlantic Base hybrid buses during the evaluation period. No battery replacements were reported since the beginning of operation for any of the hybrid buses; however, a few of the main fuses have been replaced.

- Engine system maintenance-For both the Atlantic and Ryerson Base groups of buses costs for the engine system were similar.

- Exhaust system maintenance-The repair costs for the hybrid buses were the highest in this category, because of higher parts costs.

- Fuel system maintenance-The maintenance costs for this system were essentially the same for study buses with the hybrid buses being slightly higher.

- Hydraulic system maintenance-Costs for this system were low and the same for both study groups. Only costs for hydraulic fluid replacements for scheduled maintenance were reported for both study groups.

- Nonlighting electrical systems maintenance-The costs for this category for the two study groups were essentially the same; those for the hybrid buses at Atlantic Base were only slightly higher than those in the other study group.

- Transmission maintenance-These costs were very low and similar for both groups. 
Table 12. Propulsion-Related Maintenance Cost by System

(12-month evaluation period)

\begin{tabular}{|c|c|c|c|}
\hline $\begin{array}{l}\text { Maintenance System } \\
\text { Costs }\end{array}$ & $\begin{array}{l}\text { Diesel } \\
\text { Ryerson }\end{array}$ & $\begin{array}{l}\text { Hybrid } \\
\text { Atlantic }\end{array}$ & Hybrid South \\
\hline Mileage Base & 353,785 & 371,548 & 427,331 \\
\hline \multicolumn{4}{|c|}{ Total Propulsion-Related Systems (Roll-Up) } \\
\hline Parts Cost (\$) & $13,010.39$ & $15,456.05$ & $11,901.59$ \\
\hline Labor Hours & 600.0 & 643.9 & 868.7 \\
\hline Total Cost per Mile (\$) & 0.12 & 0.13 & 0.13 \\
\hline \multicolumn{4}{|l|}{ Exhaust System Repairs } \\
\hline Parts Cost (\$) & $1,727.33$ & $4,380.21$ & 578.20 \\
\hline Labor Hours & 65.7 & 60.5 & 27.0 \\
\hline Total Cost per Mile (\$) & 0.01 & 0.02 & 0.01 \\
\hline \multicolumn{4}{|l|}{ Fuel System Repairs } \\
\hline Parts Cost (\$) & 732.51 & 896.16 & $1,079.67$ \\
\hline Labor Hours & 10.1 & 15.0 & 19.6 \\
\hline Total Cost per Mile (\$) & 0.00 & 0.01 & 0.00 \\
\hline \multicolumn{4}{|l|}{ Engine System Repairs } \\
\hline Parts Cost (\$) & $3,721.11$ & $3,529.57$ & $4,437.85$ \\
\hline Labor Hours & 251.9 & 247.0 & 271.2 \\
\hline Total Cost per Mile (\$) & 0.05 & 0.04 & 0.04 \\
\hline \multicolumn{4}{|c|}{ Electric Motor, Generator, and Battery Repairs } \\
\hline Parts Cost $(\$)$ & & 534.44 & 24.31 \\
\hline Labor Hours & & 90.5 & 332.9 \\
\hline Total Cost per Mile (\$) & & 0.01 & 0.04 \\
\hline \multicolumn{4}{|c|}{$\begin{array}{l}\text { Nonlighting Electrical System Repairs (General Electrical, Charging, } \\
\text { Cranking, Ignition) }\end{array}$} \\
\hline Parts Cost (\$) & $2,302.21$ & $1,497.78$ & $1,997.27$ \\
\hline Labor Hours & 131.5 & 141.7 & 105.3 \\
\hline Total Cost per Mile (\$) & 0.03 & 0.03 & 0.02 \\
\hline \multicolumn{4}{|l|}{ Air Intake System Repairs } \\
\hline Parts Cost $(\$)$ & 823.00 & 341.63 & 146.25 \\
\hline Labor Hours & 20.0 & 14.0 & 13.2 \\
\hline Total Cost per Mile (\$) & 0.00 & 0.00 & 0.00 \\
\hline \multicolumn{4}{|l|}{ Cooling System Repairs } \\
\hline Parts Cost $(\$)$ & 293.28 & $1,656.52$ & 330.78 \\
\hline Labor Hours & 113.0 & 62.3 & 91.1 \\
\hline Total Cost per Mile (\$) & 0.02 & 0.01 & 0.01 \\
\hline \multicolumn{4}{|l|}{ Transmission Repairs } \\
\hline Parts Cost (\$) & 0.76 & 62.10 & 238.08 \\
\hline Labor Hours & 8.0 & 12.5 & 8.5 \\
\hline Total Cost per Mile (\$) & 0.00 & 0.00 & 0.00 \\
\hline \multicolumn{4}{|l|}{ Hydraulic Repairs } \\
\hline Parts Cost (\$) & $3,410.20$ & $2,557.65$ & $3,069.18$ \\
\hline Labor Hours & 0.0 & 0.0 & 0.0 \\
\hline Total Cost per Mile (\$) & 0.01 & 0.01 & 0.01 \\
\hline
\end{tabular}

Figure 20 shows monthly propulsion-related maintenance costs for the Ryerson and Atlantic Base study groups for the evaluation period. Costs per mile for the diesel buses at Ryerson Base were between $\$ 0.10$ and \$0.15 per mile, except in January 2006 when the cost spiked above $\$ 0.20$ per mile. Early problems had to do with the auxiliary coolant heater. Later problems for 
the diesel buses had to do with the engine, turbocharger, and DPF. The costs for the hybrid buses at Atlantic Base started low then jumped in August 2005 and again from January-March 2006.

These higher costs were caused by problems with the engine, standard batteries, voltage regulator for the alternator, DPF, and auxiliary coolant heater. Most repairs related to the propulsion system (hybrid and conventional) were covered under warranty and were not included in this cost. The warranty repair costs are covered separately in this report.

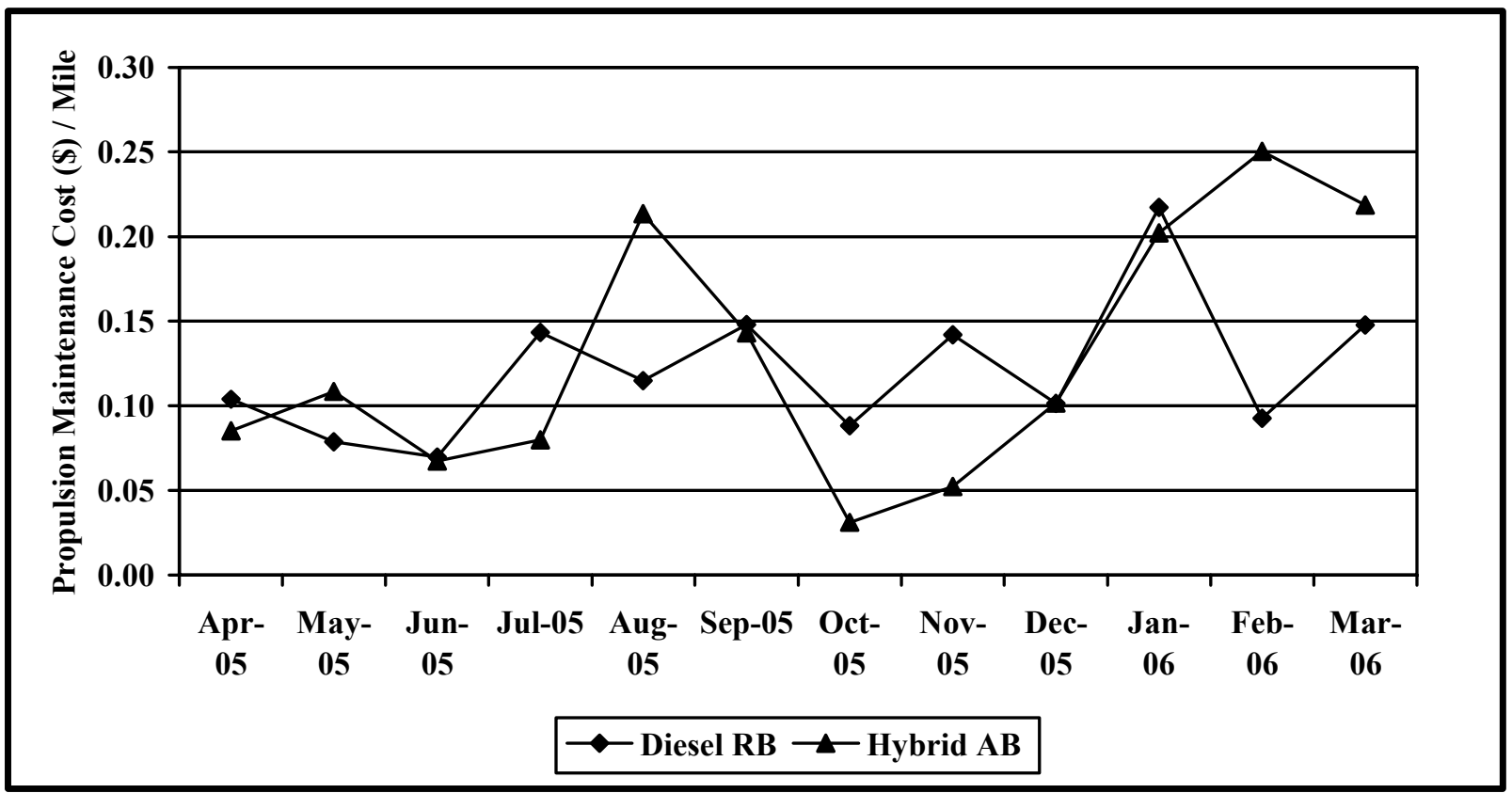

Figure 20. Propulsion-Related Maintenance Cost per Mile (12-month evaluation period)

HVAC Maintenance Costs. This category includes all maintenance actions for heating and ventilation and the air-conditioning system. The majority of the costs in this category are related to the air-conditioning system. Maintenance costs for the study groups of buses are shown in Table 13.

These costs were lowest for the hybrid buses. The parts costs for all the study groups were for major repairs for the air-conditioning system. The diesel buses at Ryerson Base had significantly more HVAC repair costs than the two hybrid groups. For all three study groups, troubleshooting work orders for the heating system were most likely the result of an issue with the auxiliary coolant heater. However, the work order descriptions were not specific enough to indicate the root cause of the "no heat" problem.

Table 13. HVAC System Maintenance Costs (12-month evaluation period)

\begin{tabular}{|l|c|c|c|c|}
\hline \multicolumn{1}{|c|}{$\begin{array}{c}\text { Study } \\
\text { Group }\end{array}$} & Mileage & $\begin{array}{c}\text { Parts } \\
\text { Cost (\$) }\end{array}$ & $\begin{array}{c}\text { Labor } \\
\text { Hours }\end{array}$ & $\begin{array}{c}\text { Cost per } \\
\text { Mile (\$) }\end{array}$ \\
\hline $\begin{array}{l}\text { Diesel } \\
\text { Ryerson } \\
\text { Base }\end{array}$ & 353,785 & $8,373.29$ & 330.6 & 0.07 \\
\hline Hybrid AB & 371,548 & $4,965.71$ & 208.5 & 0.04 \\
\hline Hybrid SB & 427,331 & $4,964.15$ & 220.9 & 0.04 \\
\hline
\end{tabular}


PMI Maintenance Costs. This category only includes labor hours for scheduled inspections of multiple bus systems during preventive maintenance. As shown in Table 14, the maintenance cost per mile for this category was essentially the same for the study groups. This indicates that, in general, the three study groups featured similar preventive maintenance practices even though they operate from three separate locations.

Table 14. PMI Maintenance Costs (12-month evaluation period)

\begin{tabular}{|l|c|c|c|c|}
\hline \multicolumn{1}{|c|}{$\begin{array}{c}\text { Study } \\
\text { Group }\end{array}$} & Mileage & $\begin{array}{c}\text { Parts } \\
\text { Cost (\$) }\end{array}$ & $\begin{array}{c}\text { Labor } \\
\text { Hours }\end{array}$ & $\begin{array}{c}\text { Cost per } \\
\text { Mile (\$) }\end{array}$ \\
\hline $\begin{array}{l}\text { Diesel } \\
\text { Ryerson } \\
\text { Base }\end{array}$ & 353,785 & 0.00 & 320.0 & 0.05 \\
\hline Hybrid AB & 371,548 & 0.00 & 367.0 & 0.05 \\
\hline Hybrid SB & 427,331 & 0.00 & 383.5 & 0.04 \\
\hline
\end{tabular}

Warranty Items. Warranty costs listed in this section are costs covered by the manufacturer(s) of the vehicle, such as providing parts at no cost to the fleet, and for labor costs that were incurred by the fleet and reimbursed by the manufacturer under the warranty period associated with the new purchase. There is a one- to two-year warranty period for many systems on the buses; the warranty period for some systems is determined by mileage or calendar time. The Allison hybrid system has a 2-year warranty. Most transit bus operators also have a fleet defect clause that covers maintenance beyond the standard warranty period. The maintenance analysis in the previous section does not include any of the costs presented here.

The KC Metro maintenance system tracks most part replacements, including those provided by the manufacturers. The cost summary in Table 15 shows warranty parts and associated labor costs in the KC Metro maintenance tracking system. Parts that were covered by warranty (and were initially listed as \$0.01) use the actual invoice price of the parts listed, with the exception of the major hybrid system replacement parts that were replaced (DPIMs) because costs are not yet available from the manufacturer. Labor costs shown are hours reimbursed multiplied by $\$ 50$ ( $\$ 50 / \mathrm{hr}$ is an estimated labor rate used throughout this report).

Table 15 shows the warranty parts costs for all three depots for the evaluation period.

For the diesel buses, the highest warranty costs were for exhaust (DPF replacements), fuel, and engine (turbocharger replacements) systems. The diesel buses experienced relatively higher warranty costs early on that were caused by DPF replacements (for a manufacturing defect) and early campaigns. In July 2005, costs for the Atlantic Base hybrid buses jumped because of the campaigns for the multiplexing modules and alternators. The costs for the diesel buses were generally low until September 2005. Beyond that, especially in November 2005, the diesel buses experienced significant turbocharger and DPF problems. There were also a few campaigns that were completed during that timeframe, including one for an alternator mounting bracket.

For the hybrid buses, all warranty costs are shown with the exception of the major electric propulsion system components that were replaced under warranty, which consisted of two DPIMs at Atlantic Base and 4 DPIMs at South Base. At the time of this report, the replacement 
costs for these components were not available and therefore are not included in the total. Also note that $\mathrm{KCM}$ is currently in the process of replacing improper cooling lines and fittings to the DPIMs on some South Base buses. These improper cooling lines were delivered with the earlier South Base deliveries only. The Atlantic Base hybrids had the correct fittings installed on the bus when delivered. Three of the six DPIMs failed with the improper cooling line installed and this may have been a contributing factor in these three DPIM failures (the other three had correct fittings installed prior to failure). The warranty costs for hybrid drive batteries and electrical drive units totaled approximately $\$ 1,000$ for the Atlantic Base buses and approximately $\$ 6,200$ for the South Base buses during the evaluation period. The Atlantic Base hybrid buses reported lower engine warranty costs than the nonhybrid Ryerson Base buses.

High warranty costs were reported for each of the three study groups for the nonlighting electrical category, which was caused by issues with the voltage regulators, alternators, and starters. Some additional warranty costs in the nonlighting electrical category were incurred for campaign activities for the multiplexing modules.

Both the hybrid buses at South Base and the diesel buses at Ryerson Base were placed into service months before the Atlantic Base hybrid buses were. This allowed the manufacturers to troubleshoot and resolve several warranty/campaign issues before the Atlantic Base hybrid buses were placed into service. Figure 21 shows average monthly warranty costs (excluding DPIM replacement) from the beginning of operation through March 2006 for the study buses. 
Table 15. Warranty Costs by Bus System for Evaluation Period (\$)

\begin{tabular}{|c|c|c|c|c|c|c|c|c|c|}
\hline \multirow[t]{2}{*}{ System } & \multicolumn{3}{|c|}{ Diesel Ryerson Base } & \multicolumn{3}{|c|}{ Hybrid AB } & \multicolumn{3}{|c|}{ Hybrid SB } \\
\hline & Parts & Labor & Total & Parts & Labor & Total & Parts & Labor & Total \\
\hline HVAC & $4,606.20$ & 605.00 & $5,211.20$ & $2,813.73$ & 255.00 & $3,068.73$ & $3,423.11$ & $1,000.00$ & $4,423.11$ \\
\hline $\begin{array}{l}\text { Cab, Body, } \\
\text { Accessories }\end{array}$ & $2,784.70$ & 380.00 & $3,164.70$ & 25.78 & 675.00 & 700.78 & 99.88 & 700.00 & 799.88 \\
\hline Air, General & 0.00 & 0.00 & 0.00 & 70.86 & 80.00 & 150.86 & 70.86 & 75.00 & 145.86 \\
\hline Suspension & 0.00 & 0.00 & 0.00 & 133.32 & 125.00 & 258.32 & 0.00 & 0.00 & 0.00 \\
\hline Axles & 763.42 & 375.00 & $1,138.42$ & $4,688.57$ & 45.00 & $4,733.57$ & $5,605.25$ & $1,745.00$ & $7,350.25$ \\
\hline Brakes & 0.77 & 25.00 & 25.77 & 0.00 & 0.00 & 0.00 & 0.00 & 250.00 & 250.00 \\
\hline Steering & 504.79 & 825.00 & $1,329.79$ & $1,912.35$ & 350.00 & $2,262.35$ & 0.00 & 0.00 & 0.00 \\
\hline Transmission & 137.94 & 102.50 & 240.44 & 493.26 & 0.00 & 493.26 & 24.84 & 75.00 & 99.84 \\
\hline Lighting & 0.00 & 0.00 & 0.00 & 8.37 & 25.00 & 33.37 & 0.00 & 0.00 & 0.00 \\
\hline $\begin{array}{l}\text { Nonlighting } \\
\text { Electrical }\end{array}$ & $8,703.44$ & $2,475.00$ & $11,178.44$ & $29,203.43$ & $2,537.50$ & $31,740.93$ & $20,160.62$ & $2,587.50$ & $22,748.12$ \\
\hline Air Intake & 524.16 & 550.00 & $1,074.16$ & 116.48 & 150.00 & 266.48 & 349.44 & 450.00 & 799.44 \\
\hline Cooling & $14,826.79$ & $1,625.00$ & $16,451.79$ & $3,483.75$ & $1,800.00$ & $5,283.75$ & $3,844.50$ & $1,475.00$ & $5,319.50$ \\
\hline Exhaust & $18,711.26$ & 525.00 & $19,236.26$ & $5,776.11$ & 0.00 & $5,776.11$ & $12,062.85$ & 325.00 & $12,387.85$ \\
\hline Fuel & $5,121.79$ & 735.00 & $5,856.79$ & 0.00 & 300.00 & 300.00 & $8,906.51$ & $1,760.00$ & $10,666.51$ \\
\hline Engine & $14,028.34$ & $3,515.00$ & $17,543.34$ & $2,672.15$ & $1,155.00$ & $3,827.15$ & $22,677.09$ & $2,638.50$ & $25,315.59$ \\
\hline $\begin{array}{l}\text { Electric } \\
\text { Propulsion* }\end{array}$ & 0.00 & 0.00 & 0.00 & $1,625.86^{*}$ & 500.00 & $2,125.86$ & $7,126.74^{*}$ & $1,375.00$ & $8,501.74$ \\
\hline $\begin{array}{r}\text { DPIMs Replaced } \\
\text { Battery Packs } \\
\text { Replaced }\end{array}$ & $\mathrm{N} / \mathrm{A}$ & - & - & 2 & - & - & 4 & - & - \\
\hline $\begin{array}{r}\text { Drive Units } \\
\text { Replaced }\end{array}$ & N/A & - & - & 0 & - & - & 0 & - & - \\
\hline $\begin{array}{l}\text { Articulation } \\
\text { Joint }\end{array}$ & 946.46 & 0.00 & 946.46 & 946.46 & 0.00 & 946.46 & $1,419.69$ & 0.00 & $1,419.69$ \\
\hline Total & $71,660.06$ & $11,737.50$ & $83,397.56$ & $53,970.48^{*}$ & $7,997.50$ & $61,967.98$ & $85,771.38^{*}$ & $14,456.00$ & $100,227.38$ \\
\hline
\end{tabular}

* costs are not available for major electric propulsion components replaced (DPIMs)

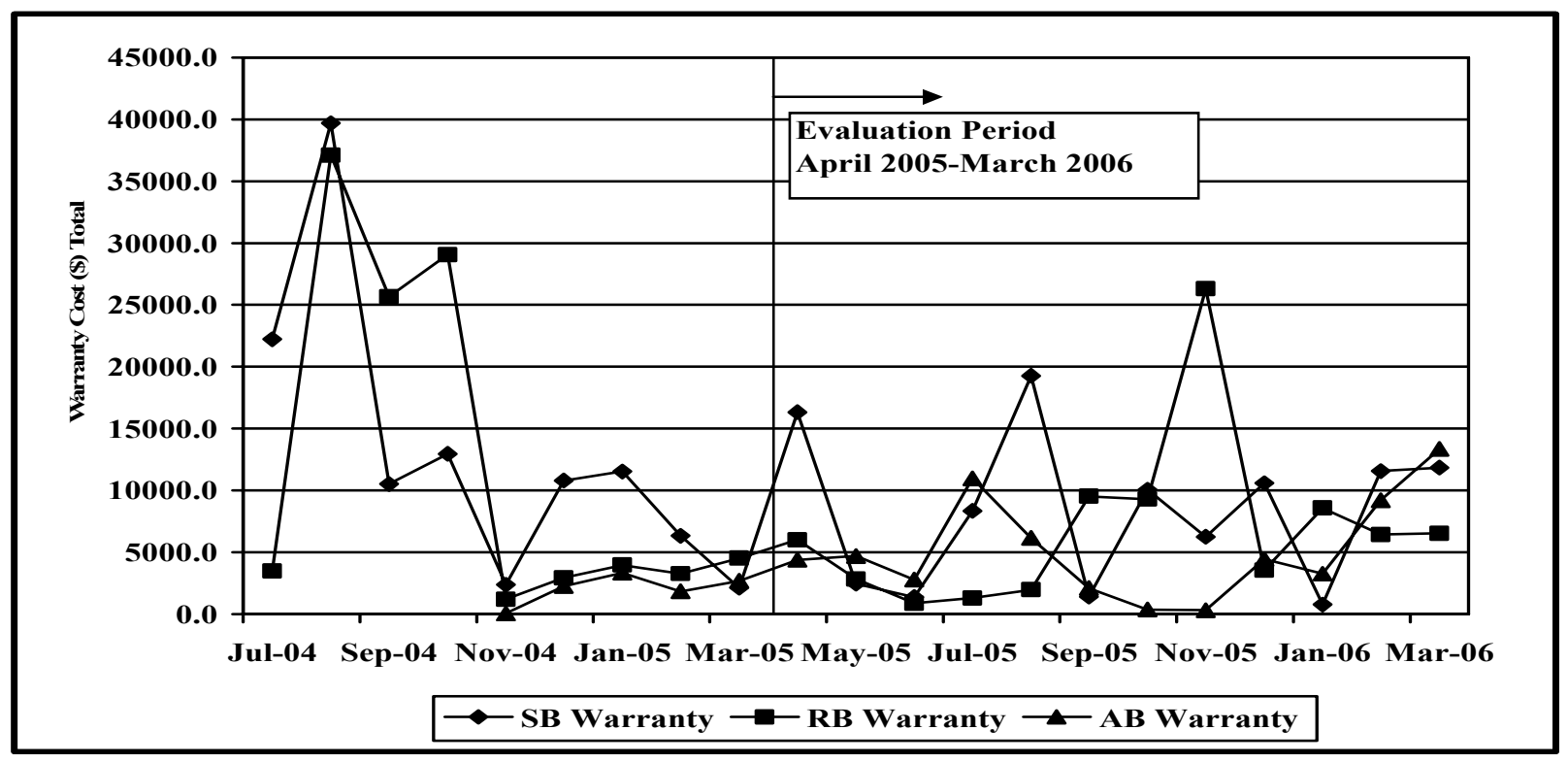

Figure 21. Monthly Total Warranty Cost (\$) (excluding DPIM replacements) 


\section{Road Call Analysis}

A road call (RC) or revenue vehicle system failure (so named for the National Transit Database ${ }^{3}$ ) is defined as a failure of an in-service bus that causes the bus to be replaced in route or results in a significant schedule delay. If the problem can be repaired during a layover and the schedule is not affected, this is not considered an RC. This analysis includes only RCs that were caused by "chargeable" failures. Chargeable RCs involve systems that can physically disable the bus from operating en route, such as interlocks (doors), the engine, etc. The analysis does not include RCs for things such as radios or destination signs.

Figure 22 shows cumulative miles between road calls (MBRC) and Table 16 breaks down the RCs by vehicle system for all three study groups for the evaluation period. There are two lines for each study group; one is for the MBRC for all RCs and the other is for the MBRC only for propulsion-related RCs. The MBRC for all RCs for the Ryerson and Atlantic study groups were nearly the same by the end of the evaluation period-4,954 MBRC for the hybrid buses and 5,896 MBRC for the diesel buses. The propulsion-related MBRC for the Atlantic Base hybrid buses was 10,616; for the diesel buses it was 12,199, or $13 \%$ higher.

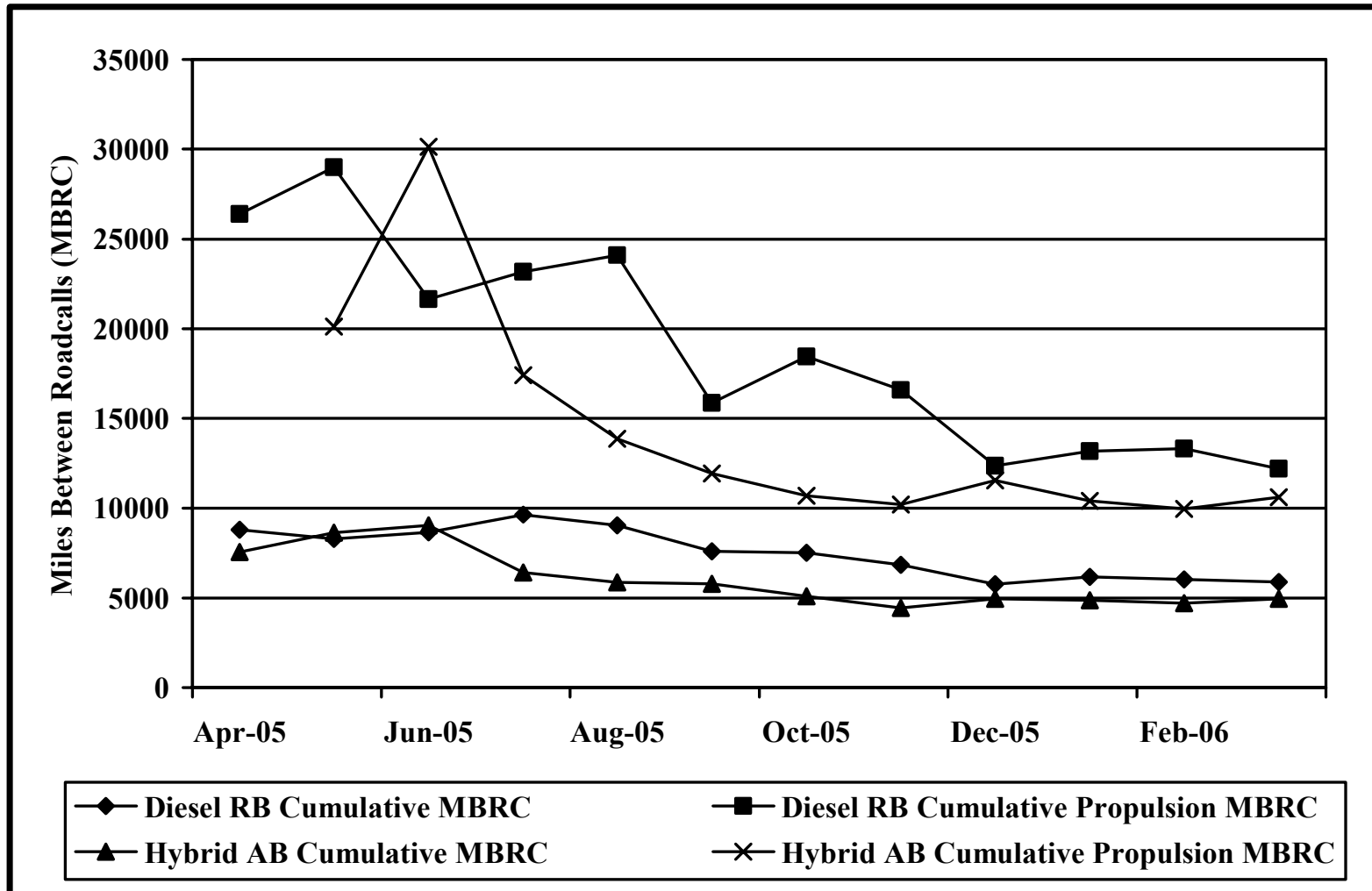

Figure 22. Total and Propulsion-Only Cumulative MBRC (12-month evaluation period)

\footnotetext{
${ }^{3}$ Revenue vehicle system failures are defined for the FTA's National Transit Database in the Reporting Manual Resource Module, which can be found at www.ntdprogram.com/NTD/ReportingManual/2005/Annual/PDFFiles/2005\%20Resource\%20Module.pdf.
} 
As shown in Table 16, the top three system categories for the most RCs for the diesel buses were engine, doors and interlock, and cooling problems (in that order). The top three system categories with the most RCs for the hybrid buses at Atlantic Base were doors and interlock, engine, and a tie for third (lighting, cooling, fuel, and wheelchair ramp). The top three system categories with the most RCs for the hybrid buses at South Base were the electric propulsion, engine, and doors and interlock. The RCs for electric propulsion were related to early problems with the cooling of the DPIM.

Table 16. Summary of Road Calls by System (12-month evaluation period)

\begin{tabular}{|c|c|c|c|c|c|c|}
\hline \multirow[b]{2}{*}{ System } & \multicolumn{2}{|c|}{ Diesel RB } & \multicolumn{2}{|c|}{ Hybrid AB } & \multicolumn{2}{|c|}{ Hybrid SB } \\
\hline & $\begin{array}{l}\text { Road } \\
\text { Calls }\end{array}$ & $\begin{array}{c}\text { Percent } \\
(\%)\end{array}$ & $\begin{array}{l}\text { Road } \\
\text { Calls }\end{array}$ & $\begin{array}{c}\text { Percent } \\
(\%)\end{array}$ & $\begin{array}{l}\text { Road } \\
\text { Calls }\end{array}$ & $\begin{array}{c}\text { Percent } \\
(\%)\end{array}$ \\
\hline HVAC & 3 & 5 & 12 & 16 & 9 & 10 \\
\hline Doors and Interlock & 6 & 10 & 8 & 11 & 13 & 15 \\
\hline Wipers & 2 & 3 & 1 & 1 & 3 & 3 \\
\hline Air, General & 2 & 3 & 0 & 0 & 2 & 2 \\
\hline Brakes & 2 & 3 & 5 & 7 & 3 & 3 \\
\hline Steering & 6 & 10 & 3 & 4 & 0 & 0 \\
\hline Suspension & 1 & 2 & 2 & 3 & 2 & 2 \\
\hline Axles & 2 & 3 & 2 & 3 & 1 & 1 \\
\hline Transmission* & 1 & 2 & 0 & 0 & 0 & 0 \\
\hline Nonlighting Electrical $^{*}$ & 11 & 18 & 10 & 13 & 10 & 11 \\
\hline Lighting & 4 & 7 & 4 & 5 & 2 & 2 \\
\hline Cooling* & 6 & 10 & 7 & 10 & 6 & 7 \\
\hline Exhaust* & 1 & 2 & 1 & 1 & 1 & 1 \\
\hline Fuel $^{*}$ & 0 & 0 & 3 & 4 & 2 & 2 \\
\hline Engine* $^{*}$ & 10 & 17 & 10 & 13 & 15 & 16 \\
\hline Electric Propulsion* & 0 & 0 & 4 & 5 & 16 & 18 \\
\hline Wheelchair Ramp & 2 & 3 & 3 & 4 & 3 & 3 \\
\hline Articulation Joint & 1 & 2 & 0 & 0 & 4 & 4 \\
\hline Total & 60 & 100 & 75 & 100 & 91 & 100 \\
\hline All MBRC & 5,896 & & 4,954 & & 4,696 & \\
\hline Propulsion MBRC & 12,199 & & 10,616 & & 8,547 & \\
\hline
\end{tabular}

${ }^{*}=$ Propulsion System Related Groups

\section{Summary of Costs}

Table 17 summarizes fuel and maintenance costs per mile for the study groups. The table shows the costs for each bus and the group average. The total cost for the hybrid buses at Atlantic Base were $15 \%$ lower than those of the diesel buses ( $\$ 0.19$ per mile difference). 
Table 17. Summary of Costs per Mile

\begin{tabular}{|c|c|c|c|}
\hline Bus & $\begin{array}{l}\text { Fuel Cost per } \\
\text { Mile (\$) }\end{array}$ & $\begin{array}{l}\text { Maintenance Cost } \\
\text { per Mile (\$) }\end{array}$ & $\begin{array}{l}\text { Total Cost per } \\
\text { Mile (\$) }\end{array}$ \\
\hline \multicolumn{4}{|l|}{ Diesel RB } \\
\hline 2880 & 0.78 & 0.50 & 1.28 \\
\hline 2881 & 0.80 & 0.48 & 1.28 \\
\hline 2882 & 0.79 & 0.44 & 1.23 \\
\hline 2883 & 0.80 & 0.43 & 1.23 \\
\hline 2884 & 0.81 & 0.46 & 1.27 \\
\hline 2885 & 0.76 & 0.46 & 1.22 \\
\hline 2886 & 0.81 & 0.41 & 1.22 \\
\hline 2887 & 0.80 & 0.39 & 1.19 \\
\hline 2888 & 0.77 & 0.49 & 1.26 \\
\hline 2889 & 0.80 & 0.59 & 1.39 \\
\hline Avg. & 0.79 & 0.46 & 1.25 \\
\hline \multicolumn{4}{|c|}{ Hybrid AB } \\
\hline 2780 & 0.63 & 0.48 & 1.11 \\
\hline 2781 & 0.62 & 0.63 & 1.25 \\
\hline 2782 & 0.65 & 0.49 & 1.14 \\
\hline 2783 & 0.63 & 0.39 & 1.02 \\
\hline 2784 & 0.60 & 0.43 & 1.03 \\
\hline 2785 & 0.63 & 0.40 & 1.03 \\
\hline 2786 & 0.61 & 0.38 & 0.99 \\
\hline 2787 & 0.64 & 0.50 & 1.14 \\
\hline 2788 & 0.62 & 0.46 & 1.08 \\
\hline 2789 & 0.62 & 0.34 & 0.96 \\
\hline Avg. & 0.62 & 0.44 & 1.06 \\
\hline \multicolumn{4}{|c|}{ Hybrid SB } \\
\hline 2640 & 0.54 & 0.48 & 1.02 \\
\hline 2641 & 0.53 & 0.47 & 1.00 \\
\hline 2642 & 0.53 & 0.35 & 0.88 \\
\hline 2643 & 0.53 & 0.34 & 0.87 \\
\hline 2644 & 0.54 & 0.44 & 0.98 \\
\hline 2645 & 0.55 & 0.44 & 0.99 \\
\hline 2647 & 0.53 & 0.42 & 0.95 \\
\hline 2648 & 0.51 & 0.42 & 0.93 \\
\hline 2649 & 0.51 & 0.34 & 0.85 \\
\hline Avg. & 0.53 & 0.41 & 0.94 \\
\hline
\end{tabular}

\section{Laboratory Emissions Testing}

Tests were performed on one hybrid bus (of the 235) and one conventional bus (of the 30) during May-June 2005 to determine the emissions and fuel economy benefits of the hybrid electric powertrain being evaluated on site in King County. The tests were conducted over four driving cycles: Central Business District (CBD), Orange County (OCTA), Manhattan, and a custom test cycle developed from in-use data on the King County Metro (KCM) fleet's operation. To evaluate the effects of additional engine and vehicle loading due to grade, select cycles were repeated with and without this added load. Vehicle exhaust emissions, fuel consumption, and state of charge of the energy storage system were measured for repeated test conditions. 
The vehicles were tested at NREL's ReFUEL Laboratory in Denver, Colorado. The laboratory includes a heavy-duty vehicle (chassis) test cell and an engine dynamometer test cell with emissions measurement capability. Regulated emissions measurements are performed using procedures consistent with the Code of Federal Regulations (CFR) title 40, section 86, subpart N. Instrumentation and sensors at the laboratory are maintained with National Institute of Standards and Technology-traceable calibration. Test procedures, calibrations, and measurement accuracies are maintained to meet requirements outlined in the current CFR title 40, section 86 , subpart $\mathrm{N}$.

The test vehicles were installed on the chassis dynamometer, shown in Figure 23. All sensors shown were monitored and recorded continuously by the ReFUEL data acquisition system throughout each test cycle run, unless otherwise noted. Detailed results of this testing are included in the report, "KCM Transit Emissions", which is available at

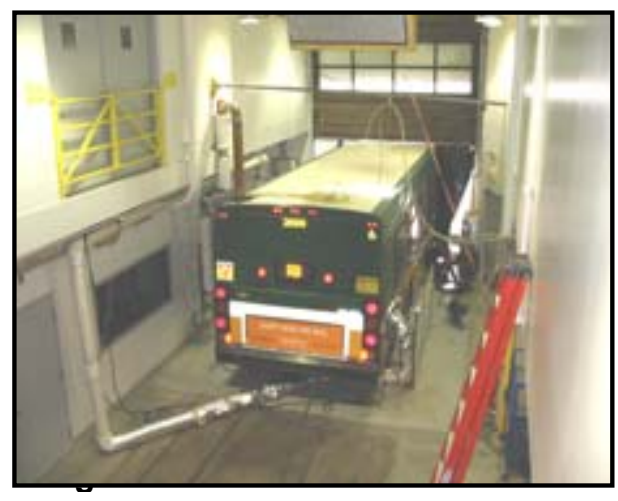
www.nrel.gov/vehiclesandfuels/ahhps/publications.html.

Fuel economy results for the buses are shown in Table 18. Emissions results (for NOx, PM, CO, and $\mathrm{CO}_{2}$ ) are shown in Table 19.

Table 18. Fuel Economy of Buses on Various Cycles on Chassis Dynamometer

\begin{tabular}{|l|c|c|c|c|c|}
\hline & & & & KCM, \\
& Manhattan & OCTA & CBD & KCM & no grade \\
\hline Conventional Bus Fuel Economy (mpg) & 1.46 & 2.15 & 2.19 & 2.90 & 3.03 \\
\hline Hybrid Bus Fuel Economy (mpg) & 2.56 & 3.24 & 3.25 & 3.78 & 3.98 \\
\hline Fuel Economy (mpg) \% Increase w/Hybrid Bus & $74.6 \%$ & $50.6 \%$ & $48.3 \%$ & $30.3 \%$ & $31.4 \%$ \\
\hline
\end{tabular}

Table 19. Average Values for Emission Results of Buses on Specified Cycles*

\begin{tabular}{|l|c|c|c|c|c|c|c|c|}
\hline & \multicolumn{2}{|c|}{ Manhattan } & \multicolumn{2}{c|}{ OCTA } & \multicolumn{2}{c|}{ CBD } & \multicolumn{2}{c|}{ KCM } \\
\cline { 2 - 10 } & Diesel & Hybrid & Diesel & Hybrid & Diesel & Hybrid & Diesel & Hybrid \\
\hline $\begin{array}{l}\text { NOx } \\
\text { (gram/mile) }\end{array}$ & 29.58 & 18.12 & 18.91 & 13.51 & 19.67 & 14.44 & 14.74 & 12.11 \\
\hline $\begin{array}{l}\text { PM } \\
\text { (gram/mile) }\end{array}$ & 0.380 & .003 & 0.050 & 0.024 & 0.101 & 0.003 & .108 & 0.187 \\
\hline $\begin{array}{l}\text { CO } \\
\text { (gram/mile) }\end{array}$ & 3.13 & 2.81 & 2.29 & 1.55 & 1.77 & 1.55 & 0.66 & 0.27 \\
\hline $\begin{array}{l}\text { THC } \\
\text { (gram/mile) }\end{array}$ & 0.04 & 0.05 & 0.03 & 0.03 & 0.12 & 0.03 & 0.04 & 0.02 \\
\hline $\begin{array}{l}\text { CO } \\
\text { (gram/mile) }\end{array}$ & 6714 & 3771 & 4579 & 3001 & 4587 & 2991 & 3446 & 2614 \\
\hline
\end{tabular}

${ }^{*}$ Average of at least three runs; see detailed report for measured variation between runs. 


\section{Future Work}

All the new diesel and hybrid articulated buses from New Flyer have been delivered and have been in service since at least December 2004. This final evaluation report provides results from a 12-month evaluation period. The first six months covered in this report included operation of the hybrid buses in the downtown transit tunnel. The tunnel is now closed, and the second 6 months of operation were completed outside the transit tunnel. The HUSH mode feature of the hybrid buses was deactivated via software in October 2005 to coincide with the tunnel closure. The tunnel is planned to reopen in 2007 and HUSH mode will be reactivated.

KC Metro has just issued an RFP to add 20 more hybrid buses to its fleet. The RFP also includes an additional 60-month supply option for up to 340 more hybrid and conventional powered articulated low floor buses. 


\section{Contacts}

\section{U.S. Department of Energy}

Lee Slezak

Manager, Advanced Vehicle Testing Activity

Phone: 202-586-2335

E-mail: lee.slezak@ee.doe.gov

National Renewable Energy Laboratory

Kevin Walkowicz

Senior Project Engineer

Phone: 303-275-4492

E-mail: kevin_walkowicz@nrel.gov

\section{King County Metro Transit}

Todd Gibbs

Senior Program Administrator

Phone: 206-684-2878

E-mail: todd.gibbs@metrokc.gov

\section{GM Allison Electric Drives}

Peter Chiang

Vehicle/Field Engineering

Phone: 317-915-2748

E-mail: peter.chiang@gm.com

\section{New Flyer Industries}

G. Paul Zanetel

Chief Technical Advisor

Phone: 204-982-8180

E-mail: paul_zanetel@,newflyer.com

\section{Caterpillar Inc.}

Dave Bradshaw

Truck Engine District Manager, Northwest Region

Phone: 425-562-9659

E-mail: bradshaw_david_G@cat.com

\section{Battelle}

Kevin Chandler

Program Manager

Phone: 614-424-5127

E-mail: chandlek@battelle.org 


\section{Acronyms and Abbreviations}

$\begin{array}{ll}\text { AB } & \text { Atlantic Base } \\ \text { AVTA } & \text { Advanced Vehicle Testing Activity } \\ \text { B5 } & \text { biodiesel blend at 5\% } \\ \text { bhp } & \text { brake horsepower } \\ \text { CAT } & \text { Caterpillar } \\ \text { CNG } & \text { compressed natural gas } \\ \text { CO } & \text { carbon monoxide } \\ \text { DDC } & \text { Detroit Diesel Corporation } \\ \text { DOC } & \text { diesel oxidation catalyst } \\ \text { DOE } & \text { U.S. Department of Energy } \\ \text { DPF } & \text { diesel particulate filter } \\ \text { DPIM } & \text { dual-power inverter module } \\ \text { EPA } & \text { U.S. Environmental Protection Agency } \\ \text { EGR } & \text { exhaust gas recirculation } \\ \text { ft } & \text { feet } \\ \text { ft-lb } & \text { foot-pounds } \\ \text { FTA } & \text { Federal Transit Administration } \\ \text { g/bhp-hr } & \text { grams per brake horsepower-hour } \\ \text { GM } & \text { General Motors } \\ \text { GVWR } & \text { gross vehicle weight rating } \\ \text { HC } & \text { hydrocarbons } \\ \text { HEV } & \text { hybrid electric vehicle } \\ \text { hp } & \text { horsepower } \\ \text { HVAC } & \text { heating, ventilation, and air-conditioning } \\ \text { in. } & \text { inches } \\ \text { KC Metro } & \text { King County Metro Transit } \\ \text { kW } & \text { kilowatts } \\ \text { L } & \text { liter } \\ \text { lb } & \text { pounds } \\ \text { LNG } & \text { liquefied natural gas } \\ \text { MBRC } & \text { miles between road calls } \\ \text { mpg } & \text { miles per gallon } \\ \text { mph } & \text { miles per hour } \\ \text { NREL } & \text { National Renewable Energy Laboratory } \\ \text { NMHC } & \text { nonmethane hydrocarbons } \\ \text { NOx } & \text { oxides of nitrogen } \\ \text { NTD } & \text { National Transit Database } \\ \text { PM } & \text { particulate matter } \\ \text { ppm } & \text { parts per million } \\ \text { PMI } & \text { preventive maintenance inspection } \\ \text { RB } & \text { Ryerson Base } \\ \text { RC } & \text { road call } \\ \text { R\&D } & \text { research and development } \\ & \end{array}$




$\begin{array}{ll}\text { RFP } & \text { request for proposals } \\ \text { rpm } & \text { revolutions per minute } \\ \text { SB } & \text { South Base } \\ \text { THC } & \text { total hydrocarbon } \\ \text { ULSD } & \text { ultra-low-sulfur diesel } \\ \text { V } & \text { volts } \\ \text { VDC } & \text { volts direct current }\end{array}$




\section{Bibliography}

Barnitt, R., 2006, Case Study: Ebus Hybrid Electric Buses and Trolleys, National Renewable Energy Laboratory, Golden, CO, NREL/TP-540-38749

Battelle, 1997, Raley's LNG Truck Fleet, Start-Up Experience, National Renewable Energy Laboratory, Golden, CO, NREL/BR-540-23402

Battelle, 1999, Waste Management's LNG Truck Fleet, Start-Up Experience, National Renewable Energy Laboratory, Golden, CO, NREL/BR-540-26617

Battelle, 2000, DART's LNG Bus Fleet, Start-Up Experience, National Renewable Energy Laboratory, Golden, CO, NREL/BR-540-28124

Battelle/NREL, 2001, Advanced Technology Vehicles in Service, Diesel Hybrid electric Buses, National Renewable Energy Laboratory, Golden, CO, NREL/FS-540-30736.

Battelle/NREL, 2002, NYCT's Diesel Hybrid electric Buses, Program Status Update, National Renewable Energy Laboratory, Golden, CO, NREL/BR-540-31668

Chandler, K., 2006, Ten Years of Compressed Natural Gas (CNG) Operations at SunLine Transit Agency, National Renewable Energy Laboratory, Golden, CO, NREL/SR-540-39180

Chandler, K., Eudy, L., 2003, ThunderPower, Bus Evaluation at SunLine Transit Agency, National Renewable Laboratory, Golden, CO, DOE/GO-102003-1786

Chandler, K., Eudy, L., Eberts, E., 2006, New York City Transit Hybrid and CNG Transit Buses: Interim Evaluation Results, National Renewable Energy Laboratory, Golden, CO, NREL/TP-540-38843

Chandler, K., Norton, P., Clark, N., 2000, DART's LNG Bus Fleet, Final Results, National Renewable Energy Laboratory, Golden, CO, NREL/BR-540-28739

Chandler, K., Norton, P., Clark, N., 2000, Raley's LNG Truck Fleet, Final Results, National Renewable Energy Laboratory, Golden, CO, NREL/BR-540-27678

Chandler, K., Norton, P., Clark, N., 2001, Waste Management's LNG Truck Fleet, Final Results, National Renewable Energy Laboratory, Golden, CO, NREL/BR-540-29073

Chandler, K., Proc, K., 2004, Norcal Prototype LNG Truck Fleet, Final Results, National Renewable Energy Laboratory, Golden, CO, DOE/GO-102004-1920

Chandler, K., Vertin, K., Alleman, T., Clark, N., 2003, Ralphs Grocery Company EC-Diesel Truck Fleet: Final Results, National Renewable Energy Laboratory, Golden, CO, NREL/BR-540-31363

Chandler, K., Walkowicz, K., 2006, King County Metro Transit Hybrid Articulated Buses: Interim Evaluation Results, National Renewable Energy Laboratory, Golden, CO, NREL/TP-540-39742

Chandler, K., Walkowicz, K., Eudy, L., 2002, New York City Transit Diesel Hybrid electric Buses: Final Results, National Renewable Energy Laboratory, Golden, CO, NREL/BR-540-32427 
Chandler, L., Barnitt, R., 2006, New York City Transit (NYCT) Hybrid and CNG Transit Buses: Final Evaluation Results, National Renewable Energy Laboratory, Golden, CO, NREL/TP-540-40125

Eudy, L., 2002, Natural Gas in Transit Fleets: A Review of the Transit Experience, National Renewable Energy Laboratory, Golden, CO, NREL/TP-540-31479

Eudy, L., Gifford, M., 2003, Challenges and Experiences with Electric Propulsion Transit Buses in the United States, National Renewable Energy Laboratory, Golden, CO, DOE/GO-102003-1791

Motta, R., Norton, P., Kelly, K., Chandler, K., Schumacher, L., Nigel, N., 1996, Alternative Fuel Transit Buses, Final Results from the National Renewable Energy Laboratory (NREL) Vehicle Evaluation

Program, National Renewable Energy Laboratory, Golden, CO, NREL/TP-425-20513

NREL, 2002, Advanced Technology Vehicles in Service, Norcal Waste Systems, Inc., National Renewable Energy Laboratory, Golden, CO, NREL/FS-540-32808

NREL, 2002, General Evaluation Plan, Fleet Test \& Evaluation Projects, National Renewable Energy Laboratory, Golden, CO, NREL/BR-540-32392

NREL, 2003, Advanced Technology Vehicles in Service: MTA New York City Transit, Diesel Hybrid electric Buses, National Renewable Energy Laboratory, Golden, CO, NREL/FS-540-33397

NREL, 2004, Advanced Technology Vehicles in Service, Indianapolis Public Transportation, National Renewable Energy Laboratory, Golden, CO, DOE/GO-102004-1986

NREL, 2004, Advanced Technology Vehicles in Service, King County Metro Transit, National Renewable Energy Laboratory, Golden, CO, DOE/GO-102004-2026

NREL, 2005, Advanced Technology Vehicles in Service, Knoxville Area Transit, National Renewable Energy Laboratory, Golden, CO, DOE/GO-102005-2085

NREL, 2005, Advanced Technology Vehicles in Service: New York City Transit Drives Hybrid electric Buses into the Future, National Renewable Energy Laboratory, Golden, CO, DOE/GO-102005-2009 


\section{Appendix: Fleet Summary Statistics}

\begin{tabular}{|c|c|c|c|}
\hline \multicolumn{4}{|c|}{ King County Metro (Seattle, WA) Fleet Summary Statistics } \\
\hline \multicolumn{4}{|c|}{\begin{tabular}{|l|l|} 
Evaluation Period Only &
\end{tabular}} \\
\hline \multicolumn{4}{|l|}{ Fleet Operations and Economics } \\
\hline & Diesel & Hybrid & Hybrid \\
\hline & Ryerson & Atlantic & South \\
\hline Number of Vehicles & 10 & 10 & $\overline{9}$ \\
\hline Period Used for Fuel Analysis & $4 / 05-3 / 06$ & $4 / 05-3 / 06$ & $4 / 05-3 / 06$ \\
\hline Total Number of Months in Period & 12 & 12 & 12 \\
\hline Fuel Analysis Base Fleet Mileage & 350,567 & 362,049 & 379,328 \\
\hline Period Used for Maintenance Op Analysis & $4 / 05-3 / 06$ & $4 / 05-3 / 06$ & $4 / 05-3 / 06$ \\
\hline Total Number of Months in Period & 12 & 12 & 12 \\
\hline Maintenance Analysis Base Fleet Mileage & 353,785 & 371,548 & 427,331 \\
\hline Average Monthly Mileage per Vehicle & 2,948 & 3,096 & 3,957 \\
\hline Fleet Fuel Usage in Gal. & 139,996 & 114,054 & 101,174 \\
\hline Representative Fleet MPG & 2.50 & 3.17 & 3.75 \\
\hline Hybrid compared to Diesel & & $27 \%$ & $50 \%$ \\
\hline \multirow[t]{2}{*}{ Average Fuel Cost as Reported } & 1.98 & 1.98 & 1.98 \\
\hline & per Gal D2 & per Gal D2 & per Gal D2 \\
\hline Average Fuel Cost per Energy Equivalent & 1.98 & 1.98 & 1.98 \\
\hline Fuel Cost per Mile & 0.791 & 0.624 & 0.528 \\
\hline Number of Total Road Calls & 60 & 75 & 91 \\
\hline MBRC All Road Calls & 5,896 & 4,954 & 4,696 \\
\hline Number of Propulsion System Road Calls & 29 & 35 & 50 \\
\hline MBRC Propulsion System Road Calls & 12,199 & 10,616 & 8,547 \\
\hline Total Scheduled Repair Cost per Mile & 0.154 & 0.140 & 0.118 \\
\hline Total Unscheduled Repair cost per Mile & 0.308 & 0.304 & 0.293 \\
\hline Total Maintenance Cost per Mile & 0.462 & 0.444 & 0.411 \\
\hline Total Operating Cost per Mile & 1.252 & 1.068 & 0.939 \\
\hline \multicolumn{4}{|l|}{ Maintenance Costs } \\
\hline & Diesel & Hybrid & Hybrid \\
\hline & Ryerson & Atlantic & South \\
\hline Fleet Mileage & 353,785 & 371,548 & 427,331 \\
\hline Total Parts Cost & $32,555.04$ & $39,319.89$ & $28,181.55$ \\
\hline Total Labor Hours & 2615.4 & 2514.2 & 2946.9 \\
\hline Average Labor Cost & $130,770.00$ & $125,707.50$ & $147,346.00$ \\
\hline \multicolumn{4}{|l|}{ (@ \$50.00 per hour) } \\
\hline Total Maintenance Cost & $163,325.04$ & $165,027.39$ & 175.527 .55 \\
\hline Total Maintenance Cost per Mile & 0.462 & 0.444 & 0.411 \\
\hline
\end{tabular}




\begin{tabular}{|c|c|c|c|}
\hline \multicolumn{3}{|c|}{ Breakdown of Maintenance Costs by Vehicle System } & \multirow[b]{2}{*}{ Hybrid } \\
\hline & Diesel & Hybrid & \\
\hline & Ryerson & Atlantic & South \\
\hline Fleet Mileage & 353,785 & 371,548 & 427,331 \\
\hline \multicolumn{3}{|c|}{ Total Propulsion-Related Systems } & \\
\hline \multicolumn{3}{|c|}{ (ATA VMRS $27,30,31,32,33,41,42,43,44,45,46,65$ ) } & \\
\hline Parts Cost & $13,010.39$ & $15,456.05$ & $11,901.59$ \\
\hline Labor Hours & 600.0 & 643.9 & 868.7 \\
\hline Average Labor Cost & $30,000.00$ & $32,192.50$ & $43,433.50$ \\
\hline Total Cost (for system) & $43,010.39$ & $47,648.55$ & $55,335.09$ \\
\hline Total Cost (for system) per Mile & 0.122 & 0.128 & 0.130 \\
\hline \multicolumn{3}{|c|}{ Exhaust System Repairs (ATA VMRS 43) } & \\
\hline Parts Cost & $1,727.33$ & $4,380.21$ & 578.20 \\
\hline Labor Hours & 65.7 & 60.5 & 27.0 \\
\hline Average Labor Cost & $3,285.00$ & $3,025.00$ & $1,350.00$ \\
\hline Total Cost (for system) & $5,012.33$ & $7,405.21$ & $1,928.20$ \\
\hline Total Cost (for system) per Mile & 0.014 & 0.020 & 0.005 \\
\hline \multicolumn{3}{|c|}{ Fuel System Repairs (ATA VMRS 44) } & \\
\hline Parts Cost & 732.51 & 896.16 & $1,079.67$ \\
\hline Labor Hours & 10.1 & 15.0 & 19.6 \\
\hline Average Labor Cost & 505.00 & 750.00 & 980.00 \\
\hline Total Cost (for system) & $1,237.51$ & $1,646.16$ & $2,059.67$ \\
\hline Total Cost (for system) per Mile & 0.004 & 0.004 & 0.005 \\
\hline \multicolumn{3}{|c|}{ Power Plant (Engine) Repairs (ATA VMRS 45) } & \\
\hline Parts Cost & $3,721.11$ & $3,529.57$ & $4,437.85$ \\
\hline Labor Hours & 251.9 & 247.0 & 271.2 \\
\hline Average Labor Cost & $12,592.50$ & $12,350.00$ & $13,558.50$ \\
\hline Total Cost (for system) & $16,313.61$ & $15,879.57$ & $17,996.35$ \\
\hline Total Cost (for system) per Mile & 0.046 & 0.043 & 0.042 \\
\hline \multicolumn{3}{|c|}{ Electric Motor, Generator, and Battery Repairs (ATA VMRS 46) } & \\
\hline Parts Cost & & 534.44 & 24.31 \\
\hline Labor Hours & & 90.5 & 332.9 \\
\hline Average Labor Cost & & $4,525.00$ & $16,642.50$ \\
\hline Total Cost (for system) & & $5,059.44$ & $16,666.81$ \\
\hline Total Cost (for system) per Mile & & 0.014 & 0.039 \\
\hline \multirow{2}{*}{\multicolumn{3}{|c|}{$\begin{array}{l}\text { Electrical System Repairs (ATA VMRS 30-Electrical General, } \\
\text { 31-Charging, 32-Cranking, 33-Ignition) }\end{array}$}} & \\
\hline & & & \\
\hline Parts Cost & $2,302.21$ & $1,497.78$ & $1,997.27$ \\
\hline Labor Hours & 131.5 & 141.7 & 105.3 \\
\hline Average Labor Cost & $6,572.50$ & $7,085.00$ & $5,262.50$ \\
\hline Total Cost (for system) & $8,874.71$ & $8,582.78$ & $7,259.77$ \\
\hline Total Cost (for system) per Mile & 0.025 & 0.023 & 0.017 \\
\hline
\end{tabular}


Breakdown of Maintenance Costs by Vehicle System (continued)

\begin{tabular}{|c|c|c|c|}
\hline & Diesel & Hybrid & Hybrid \\
\hline & Ryerson & Atlantic & South \\
\hline \multicolumn{4}{|c|}{ Air Intake System Repairs (ATA VMRS 41) } \\
\hline Parts Cost & 823.00 & 341.63 & 146.25 \\
\hline Labor Hours & 20.0 & 14.0 & 13.2 \\
\hline Average Labor Cost & 997.50 & 700.00 & 660.00 \\
\hline Total Cost (for system) & $1,820.50$ & $1,041.63$ & 806.25 \\
\hline Total Cost (for system) per Mile & 0.005 & 0.003 & 0.002 \\
\hline \multicolumn{4}{|c|}{ Cooling System Repairs (ATA VMRS 42) } \\
\hline Parts Cost & 293.28 & $1,656.52$ & 330.78 \\
\hline Labor Hours & 113.0 & 62.3 & 91.1 \\
\hline Average Labor Cost & $5,647.50$ & $3,112.50$ & $4,555.00$ \\
\hline Total Cost (for system) & $5,940.78$ & $4,769.02$ & $4,885.78$ \\
\hline Total Cost (for system) per Mile & 0.017 & 0.013 & 0.011 \\
\hline \multicolumn{4}{|l|}{ Hydraulic Repairs (ATA VMRS 65) } \\
\hline Parts Cost & $3,410.20$ & $2,557.65$ & $3,069.18$ \\
\hline Labor Hours & 0.0 & 0.0 & 0.0 \\
\hline Average Labor Cost & 0.00 & 0.00 & 0.00 \\
\hline Total Cost (for system) & $3,410.20$ & $2,557.65$ & $3,069.18$ \\
\hline Total Cost (for system) per Mile & 0.010 & 0.007 & 0.007 \\
\hline \multicolumn{4}{|c|}{ Transmission Repairs (ATA VMRS 27) } \\
\hline Parts Cost & 0.76 & 62.10 & 238.08 \\
\hline Labor Hours & 8.0 & 12.5 & 8.5 \\
\hline Average Labor Cost & 200.00 & 625.00 & 425.00 \\
\hline Total Cost (for system) & 200.76 & 687.10 & 663.08 \\
\hline Total Cost (for system) per Mile & 0.001 & 0.002 & 0.002 \\
\hline \multicolumn{4}{|c|}{ Cab, Body, and Accessories Systems Repairs } \\
\hline \multicolumn{4}{|c|}{ (ATA VMRS 02-Cab and Sheet Metal, 50-Accessories, 71-Body) } \\
\hline Parts Cost & $7,503.07$ & $16,134.94$ & $6,797.54$ \\
\hline Labor Hours & 1002.4 & 1072.3 & 1039.3 \\
\hline Average Labor Cost & $50,120.00$ & $53,612.50$ & $51,962.50$ \\
\hline Total Cost (for system) & $57,623.07$ & $69,747.44$ & $58,760.04$ \\
\hline Total Cost (for system) per Mile & 0.163 & 0.188 & 0.138 \\
\hline \multicolumn{4}{|c|}{ Inspections Only - no parts replacements (101) } \\
\hline Parts Cost & 0.00 & 0.00 & 0.00 \\
\hline Labor Hours & 320.0 & 367.0 & 383.5 \\
\hline Average Labor Cost & $16,000.00$ & $18,350.00$ & $19,175.00$ \\
\hline Total Cost (for system) & $16,000.00$ & $18,350.00$ & $19,175.00$ \\
\hline Total Cost (for system) per Mile & 0.045 & 0.049 & 0.045 \\
\hline
\end{tabular}


Breakdown of Maintenance Costs by Vehicle System (continued)

\begin{tabular}{|c|c|c|c|}
\hline & Diesel & Hybrid & Hybrid \\
\hline & Ryerson & Atlantic & South \\
\hline \multicolumn{4}{|c|}{ HVAC System Repairs (ATA VMRS 01) } \\
\hline Parts Cost & $8,373.29$ & $4,965.71$ & $4,964.15$ \\
\hline Labor Hours & 330.6 & 208.5 & 220.9 \\
\hline Average Labor Cost & $16,527.50$ & $10,422.50$ & $11,045.00$ \\
\hline Total Cost (for system) & $24,900.79$ & $15,338.21$ & $16,009.15$ \\
\hline Total Cost (for system) per Mile & 0.070 & 0.041 & 0.038 \\
\hline \multicolumn{4}{|c|}{ Brake System Repairs (ATA VMRS 13) } \\
\hline Parts Cost & 8.93 & 27.77 & 4.64 \\
\hline Labor Hours & 14.5 & 48.5 & 37.3 \\
\hline Average Labor Cost & 725.00 & $2,425.00$ & $1,862.50$ \\
\hline Total Cost (for system) & 733.93 & $2,452.77$ & $1,867.14$ \\
\hline Total Cost (for system) per Mile & 0.002 & 0.007 & 0.004 \\
\hline \multicolumn{4}{|l|}{ Air System Repairs (ATA VMRS 10) } \\
\hline Parts Cost & $1,034.53$ & 547.40 & 489.19 \\
\hline Labor Hours & 35.0 & 25.4 & 43.3 \\
\hline Average Labor Cost & $1,750.00$ & $1,270.00$ & $2,162.50$ \\
\hline Total Cost (for system) & $2,784.53$ & $1,817.40$ & $2,651.69$ \\
\hline Total Cost (for system) per Mile & 0.008 & 0.005 & 0.006 \\
\hline \multicolumn{4}{|c|}{ Lighting System Repairs (ATA VMRS 34) } \\
\hline Parts Cost & 622.59 & 383.61 & 274.55 \\
\hline Labor Hours & 35.0 & 34.8 & 18.5 \\
\hline Average Labor Cost & $1,750.00$ & $1,737.50$ & 925.00 \\
\hline Total Cost (for system) & $2,372.59$ & $2,121.11$ & $1,199.55$ \\
\hline Total Cost (for system) per Mile & 0.007 & 0.006 & 0.003 \\
\hline \multicolumn{4}{|c|}{$\begin{array}{l}\text { Frame, Steering, and Suspension Repairs (ATA VMRS 14-Frame, 15-Steering, 16- } \\
\text { Suspension) }\end{array}$} \\
\hline Parts Cost & 950.97 & 929.63 & $1,390.21$ \\
\hline Labor Hours & 81.5 & 56.3 & 55.0 \\
\hline Average Labor Cost & $4,075.00$ & $2,812.50$ & $2,750.00$ \\
\hline Total Cost (for system) & $5,025.97$ & $3,742.13$ & $4,140.21$ \\
\hline Total Cost (for system) per Mile & 0.014 & 0.010 & 0.010 \\
\hline \multicolumn{4}{|c|}{$\begin{array}{l}\text { Axle, Wheel, and Drive Shaft Repairs (ATA VMRS 11-Front Axle, 12-Middle Axle, } \\
\text { 18-Wheels, 22-Rear Axle, 24-Drive Shaft) }\end{array}$} \\
\hline Parts Cost & 989.84 & 529.51 & 646.79 \\
\hline Labor Hours & 109.5 & 41.2 & 50.7 \\
\hline Average Labor Cost & $5,472.50$ & $2,060.00$ & $2,535.00$ \\
\hline Total Cost (for system) & $6,462.34$ & $2,589.51$ & $3,181.79$ \\
\hline Total Cost (for system) per Mile & 0.018 & 0.007 & 0.007 \\
\hline & & & \\
\hline
\end{tabular}




\begin{tabular}{|c|c|c|c|}
\hline \multicolumn{4}{|c|}{ Breakdown of Maintenance Costs by Vehicle System (continued) } \\
\hline & Diesel & Hybrid & Hybrid \\
\hline & Ryerson & Atlantic & South \\
\hline \multicolumn{4}{|l|}{ Tire Repairs (ATA VMRS 17) } \\
\hline Parts Cost & 0.00 & 0.00 & 0.00 \\
\hline Labor Hours & 3.0 & 4.0 & 32.0 \\
\hline Average Labor Cost & 150.00 & 200.00 & $1,600.00$ \\
\hline Total Cost (for system) & 150.00 & 200.00 & $1,600.00$ \\
\hline Total Cost (for system) per Mile & 0.000 & 0.001 & 0.004 \\
\hline \multicolumn{4}{|c|}{ Articulation Repairs (ATA VMRS 59) } \\
\hline Parts Cost & 6.30 & 345.26 & $1,712.89$ \\
\hline Labor Hours & 84.0 & 12.5 & 197.9 \\
\hline Average Labor Cost & $4,200.00$ & 625.00 & $9,895.00$ \\
\hline Total Cost (for system) & $4,206.30$ & 970.26 & $11,607.89$ \\
\hline Total Cost (for system) per Mile & 0.012 & 0.003 & 0.027 \\
\hline
\end{tabular}

Notes

1. The engine and fuel-related systems were chosen to include only those systems of the vehicles that could be directly a part of the propulsion system.

2. ATA VMRS coding is based on parts that were replaced. If there was no part replaced in a given repair, then the code was chosen by the system being worked on.

3. In general, inspections (with no part replacements) were only included in the overall totals (not by system). 101 was created to track labor costs for PM inspections.

4. ATA VMRS 02-Cab and Sheet Metal represents seats, doors, etc.; ATA VMRS 50-Accessories represents things like fire extinguishers, test kits, etc.; ATA VMRS 71-Body represent mostly windows and windshields.

5 . Average labor cost is assumed to be $\$ 50$ per hour.

6. Warranty costs are not included. 


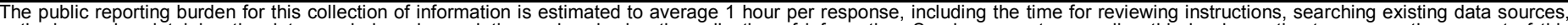

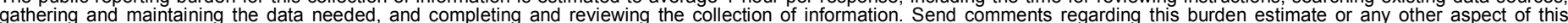

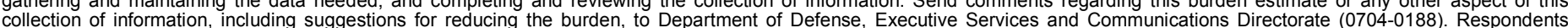

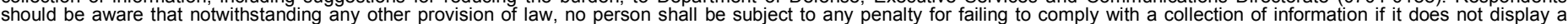

should be aware that notwithstanding

PLEASE DO NOT RETURN YOUR FORM TO THE ABOVE ORGANIZATION.

\section{REPORT DATE (DD-MM-YYYY) \\ December 2006 \\ 2. REPORT TYPE \\ Technical Report}

4. TITLE AND SUBTITLE

King County Metro Transit Hybrid Articulated Buses:

Final Evaluation Results

3. DATES COVERED (From - To) May 2005-May 2006

5a. CONTRACT NUMBER

DE-AC36-99-G010337

5b. GRANT NUMBER

5c. PROGRAM ELEMENT NUMBER

5d. PROJECT NUMBER

NREL/TP-540-40585

5e. TASK NUMBER

FC07.3000

5f. WORK UNIT NUMBER

7. PERFORMING ORGANIZATION NAME(S) AND ADDRESS(ES)

National Renewable Energy Laboratory

1617 Cole Blvd.

Golden, CO 80401-3393
8. PERFORMING ORGANIZATION REPORT NUMBER

NREL/TP-540-40585

9. SPONSORING/MONITORING AGENCY NAME(S) AND ADDRESS(ES)

10. SPONSOR/MONITOR'S ACRONYM(S) NREL

11. SPONSORING/MONITORING AGENCY REPORT NUMBER

12. DISTRIBUTION AVAILABILITY STATEMENT

National Technical Information Service

U.S. Department of Commerce

5285 Port Royal Road

Springfield, VA 22161

13. SUPPLEMENTARY NOTES

14. ABSTRACT (Maximum 200 Words)

This evaluation focused on diesel and hybrid diesel buses selected from three of KC Metro's seven operating depots or bases. All 30 of the new diesel articulated buses currently operate from the Ryerson Base depot; they are identical to the hybrid buses except for the hybrid electric propulsion systems. Ten diesel buses were selected from Ryerson Base for detailed evaluation, and 10 hybrid buses were selected from Atlantic Base for comparison.

15. SUBJECT TERMS

Evaluation; diesel buses; hybrid electric diesel buses; King County Metro; U.S. Department of Energy; Advanced Vehicle Testing Activity; AVTA; transit agency

\begin{tabular}{|l|l|l|}
\hline \multicolumn{3}{|l|}{ 16. SECURITY CLASSIFICATION OF: } \\
\hline $\begin{array}{l}\text { a. REPORT } \\
\text { Unclassified }\end{array}$ & $\begin{array}{l}\text { b. ABSTRACT } \\
\text { Unclassified }\end{array}$ & c. THIS PAGE \\
& & Unclassified \\
\hline
\end{tabular}

\begin{tabular}{|c|c|}
\hline $\begin{array}{l}\text { 17. LIMITATION } \\
\text { OF ABSTRACT }\end{array}$ & $\begin{array}{l}\text { 18. NUMBER } \\
\text { OF PAGES }\end{array}$ \\
\hline UL & \\
\hline
\end{tabular}

19a. NAME OF RESPONSIBLE PERSON

19b. TELEPHONE NUMBER (Include area code) 